Cochrane Database of Systematic Reviews

\title{
Anti-vascular endothelial growth factor for macular oedema secondary to branch retinal vein occlusion (Review)
}

Shalchi Z, Mahroo O, Bunce C, Mitry D

Shalchi Z, Mahroo O, Bunce C, Mitry D.

Anti-vascular endothelial growth factor for macular oedema secondary to branch retinal vein occlusion.

Cochrane Database of Systematic Reviews 2020, Issue 7. Art. No.: CD009510.

DOI: 10.1002/14651858.CD009510.pub3.

www.cochranelibrary.com 
TABLE OF CONTENTS

HEADER 1

ABSTRACT

PLAIN LANGUAGE SUMMARY

SUMMARY OF FINDINGS

BACKGROUND

OBJECTIVES

METHODS

RESULTS

Figure 1.

Figure 2.

Figure 3.

Figure 4.

Figure 5.

Figure 6.

DISCUSSION

AUTHORS' CONCLUSIONS

ACKNOWLEDGEMENTS

REFERENCES

CHARACTERISTICS OF STUDIES

DATA AND ANALYSES

Analysis 1.1. Comparison 1: Anti-VEGF v sham, Outcome 1: Gain of 15 letters or more at 6 months

Analysis 1.2. Comparison 1: Anti-VEGF v sham, Outcome 2: Mean VA change at 6 months

Analysis 1.3. Comparison 1: Anti-VEGF v sham, Outcome 3: Loss of 15 letters or more at 6 months

Analysis 1.4. Comparison 1: Anti-VEGF v sham, Outcome 4: Mean CRT change at 6 months

Analysis 1.5. Comparison 1: Anti-VEGF v sham, Outcome 5: Cataract

Analysis 1.6. Comparison 1: Anti-VEGF v sham, Outcome 6: Raised IOP

Analysis 1.7. Comparison 1: Anti-VEGF v sham, Outcome 7: APTC events

Analysis 1.8. Comparison 1: Anti-VEGF v sham, Outcome 8: Quality of life change

Analysis 2.1. Comparison 2: Anti-VEGF v laser, Outcome 1: Gain of 15 letters or more at 6 months

Analysis 2.2. Comparison 2: Anti-VEGF v laser, Outcome 2: Mean VA change at 6 months

Analysis 2.3. Comparison 2: Anti-VEGF v laser, Outcome 3: Mean CRT change at 6 months

Analysis 2.4. Comparison 2: Anti-VEGF v laser, Outcome 4: Cataract

Analysis 2.5. Comparison 2: Anti-VEGF v laser, Outcome 5: APTC events

Analysis 3.1. Comparison 3: Anti-VEGF v steroid, Outcome 1: Gain of 15 letters or more at 6 months

Analysis 3.2. Comparison 3: Anti-VEGF v steroid, Outcome 2: Gain of 15 letters or more at 12 months

Analysis 3.3. Comparison 3: Anti-VEGF v steroid, Outcome 3: Mean VA change at 6 months

Analysis 3.4. Comparison 3: Anti-VEGF v steroid, Outcome 4: Mean VA change at 12 months

Analysis 3.5. Comparison 3: Anti-VEGF v steroid, Outcome 5: Mean CRT change at 6 months

Analysis 3.6. Comparison 3: Anti-VEGF v steroid, Outcome 6: Mean CRT change at 12 months

Analysis 3.7. Comparison 3: Anti-VEGF v steroid, Outcome 7: Quality of life change at 12 months

Analysis 3.8. Comparison 3: Anti-VEGF v steroid, Outcome 8: Cataract

Analysis 3.9. Comparison 3: Anti-VEGF v steroid, Outcome 9: Raised IOP

Analysis 3.10. Comparison 3: Anti-VEGF v steroid, Outcome 10: APTC events

Analysis 3.11. Comparison 3: Anti-VEGF v steroid, Outcome 11: Endophthalmitis

ADDITIONAL TABLES

APPENDICES

WHAT'S NEW

HISTORY

CONTRIBUTIONS OF AUTHORS

DECLARATIONS OF INTEREST

SOURCES OF SUPPORT 
[Intervention Review]

\section{Anti-vascular endothelial growth factor for macular oedema secondary to branch retinal vein occlusion}

Zaid Shalchi1,2, Omar Mahroo¹, Catey Bunce ${ }^{3}$, Danny Mitry ${ }^{1,4}$

1Moorfields Eye Hospital NHS Foundation Trust, London, UK. ${ }^{2}$ Royal Berkshire NHS Foundation Trust, Reading, UK. ${ }^{3}$ London, UK. ${ }^{4}$ Royal Free Hospital, NHS Foundation Trust, London, UK

Contact address: Zaid Shalchi, z.shalchi@nhs.net.

Editorial group: Cochrane Eyes and Vision Group.

Publication status and date: New search for studies and content updated (conclusions changed), published in Issue 7, 2020.

Citation: Shalchi Z, Mahroo O, Bunce C, Mitry D. Anti-vascular endothelial growth factor for macular oedema secondary to branch retinal vein occlusion. Cochrane Database of Systematic Reviews 2020, Issue 7. Art. No.: CD009510. DOI: 10.1002/14651858.CD009510.pub3.

Copyright $(2020$ The Cochrane Collaboration. Published by John Wiley \& Sons, Ltd.

\section{A B S T R A C T}

\section{Background}

Branch retinal vein occlusion (BRVO) is one of the most commonly occurring retinal vascular abnormalities. The most common cause of visual loss in people with BRVO is macular oedema (MO). Grid or focal laser photocoagulation has been shown to reduce the risk of visual loss. Limitations to this treatment exist, however, and newer modalities may have equal or improved efficacy. Antiangiogenic therapy with anti-vascular endothelial growth factor (anti-VEGF) has recently been used successfully to treat MO resulting from a variety of causes.

\section{Objectives}

To investigate the efficacy and gather evidence from randomised controlled trials (RCTs) on the potential harms of anti-vascular endothelial growth factor (VEGF) agents for the treatment of macular oedema (MO) secondary to branch retinal vein occlusion (BRVO).

\section{Search methods}

We searched the Cochrane Central Register of Controlled Trials (CENTRAL) (which contains the Cochrane Eyes and Vision Trials Register) (2019, Issue 6); MEDLINE Ovid; Embase Ovid; the ISRCTN registry; ClinicalTrials.gov; and the WHO ICTRP. The date of the last search was 12 June 2019

\section{Selection criteria}

We included randomised controlled trials (RCTs) investigating BRVO. Eligible trials had to have at least six months' follow-up where antiVEGF treatment was compared with another treatment, no treatment, or placebo. We excluded trials where combination treatments (antiVEGF plus other treatments) were used; and trials that investigated the dose and duration of treatment without a comparison group (other treatment/no treatment/sham).

\section{Data collection and analysis}

Two review authors independently extracted the data using standard methodological procedures expected by Cochrane. The primary outcome was the proportion of participants with an improvement from baseline in best-corrected visual acuity of greater than or equal to 15 letters (3 lines) on the Early Treatment in Diabetic Retinopathy Study (ETDRS) Chart at six months and 12 months of follow-up. The secondary outcomes were the proportion of participants who lost greater than or equal to 15 ETDRS letters ( 3 lines) and the mean visual acuity (VA) change at six and 12 months, as well as the change in central retinal thickness (CRT) on optical coherence tomography from baseline at six and 12 months. We also collected data on adverse events and quality of life (QoL). 


\section{Main results}

We found eight RCTs of 1631 participants that met the inclusion criteria after independent and duplicate review of the search results. These studies took place in Europe, North America, Eastern Mediterranean region and East Asia. Included participants were adults aged 18 or over with VA of 20/40 or worse. Studies varied by duration of disease but permitted previously treated eyes as long as there was sufficient treatment-free interval. All anti-VEGF agents (bevacizumab, ranibizumab and aflibercept) and steroids (triamcinolone and dexamethasone) were included. Overall, we judged the studies to be at moderate or unclear risk of bias. Four of the eight studies did not mask participants or outcome assessors, or both.

One trial compared anti-VEGF to sham. At six months, eyes receiving anti-VEGF were significantly more likely to have a gain of 15 or more ETDRS letters (risk ratio (RR) 1.72, 95\% confidence interval (CI) 1.19 to 2.49 ; 283 participants; moderate-certainty evidence). Mean VA was better in the anti-VEGF group at six months compared with control (mean difference (MD) 7.50 letters, $95 \% \mathrm{Cl} 5.29$ to $9.71 ; 282$ participants; moderate-certainty evidence). Anti-VEGF also proved more effective at reducing CRT at six months (MD $-57.50 \mathrm{microns}, 95 \% \mathrm{Cl}-108.63$ to -6.37 ; 281 participants; lower CRT is better; moderate-certainty evidence). There was only very low-certainty evidence on adverse effects. There were no reports of endophthalmitis. Mean change in QoL (measured using the National Eye Institute Visual Functioning Questionnaire VFQ-25) was better in people treated with anti-VEGF compared with people treated with sham (MD 7.6 higher score, 95\% CI 4.3 to $10.9 ; 281$ participants; moderate-certainty evidence).

Three RCTs compared anti-VEGF with macular laser (total participants $=473$ ). The proportion of eyes gaining 15 or more letters was greater in the anti-VEGF group at six months (RR 2.09, 95\% Cl 1.44 to 3.05; 2 studies, 201 participants; moderate-certainty evidence). Mean VA in the anti-VEGF groups was better than the laser groups at six months (MD 9.63 letters, $95 \% \mathrm{Cl} 7.23$ to 12.03 ; 3 studies, 473 participants; moderatecertainty evidence). There was a greater reduction in CRT in the anti-VEGF group compared with the laser group at six months (MD -147.47 microns, $95 \% \mathrm{Cl}-200.19$ to $-94.75 ; 2$ studies, 201 participants; moderate-certainty evidence). There was only very low-certainty evidence on adverse events. There were no reports of endophthalmitis. QoL outcomes were not reported.

Four studies compared anti-VEGF with intravitreal steroid (875 participants). The proportion of eyes gaining 15 or more ETDRS letters was greater in the anti-VEGF group at six months (RR 1.67, 95\% Cl 1.33 to 2.10; 2 studies, 330 participants; high-certainty evidence) and 12 months (RR $1.76,95 \% \mathrm{Cl} 1.36$ to 2.28; 1 study, 307 participants; high-certainty evidence). Mean VA was better in the anti-VEGF group at six months (MD 8.22 letters, 95\% Cl 5.69 to 10.76; 2 studies, 330 participants; high-certainty evidence) and 12 months (MD 9.15 letters, 95\% Cl 6.32 to 11.97 ; 2 studies, 343 participants; high-certainty evidence). Mean CRT also showed a greater reduction in the anti-VEGF arm at 12 months compared with intravitreal steroid (MD -26.92 microns, $95 \% \mathrm{Cl}-65.88$ to 12.04 ; 2 studies, 343 participants; moderatecertainty evidence). People receiving anti-VEGF showed a greater improvement in QoL at 12 months compared to those receiving steroid (MD 3.10, 95\% Cl 0.22 to 5.98; 1 study, 307 participants; moderate-certainty evidence). Moderate-certainty evidence suggested increased risk of cataract and raised IOP with steroids. There was only very low-certainty evidence on APTC events. No cases of endophthalmitis were observed.

\section{Authors' conclusions}

The available RCT evidence suggests that treatment of MO secondary to BRVO with anti-VEGF improves visual and anatomical outcomes at six and 12 months.

\section{PLAIN LANGUAGE SUMMARY}

\section{Anti-vascular endothelial growth factor for macular oedema secondary to branch retinal vein occlusion}

\section{What is the aim of this review?}

The aim of this Cochrane Review was to find out if anti-vascular endothelial growth factor (anti-VEGF) works for the treatment of macular oedema (MO) secondary to branch retinal vein occlusion (BRVO). Cochrane researchers collected and analysed all relevant studies to answer this question and found eight studies.

Key messages The review shows that people with MO due to BRVO benefit from treatment with anti-VEGF with an increased chance of improved vision at six and 12 months when compared with no treatment, laser or steroid injection.

\section{What was studied in the review?}

There are small blood vessels at the back of the eye (retina) known as arteries (when blood comes into the eye) and veins (when blood leaves the eye). BRVO occurs when a vein that drains part of the retina becomes blocked. This can lead to swelling (oedema) at the back of eye which may result in loss of vision, particularly if it occurs at the centre of the retina (macula).

One treatment option for MO due to BRVO is anti-VEGF injections. VEGF is a molecule found in the back of the eye associated with the inflammation. Anti-VEGF blocks the action of VEGF, which can help to reduce the amount of damage. Treating MO due to BRVO is important as it can prevent sight loss occurring.

The most commonly used anti-VEGF drugs are:

- ranibizumab (Lucentis)

Anti-vascular endothelial growth factor for macular oedema secondary to branch retinal vein occlusion (Review)

Copyright (c) 2020 The Cochrane Collaboration. Published by John Wiley \& Sons, Ltd. 
- aflibercept (Eylea)

- bevacizumab (Avastin)

What are the main results of the review? Cochrane researchers found eight relevant studies. These studies took place in Europe, North America, Eastern Mediterranean region and East Asia.

One study compared anti-VEGF to no treatment (sham injection); three studies compared anti-VEGF to another type of treatment (laser); and four studies compared anti-VEGF to steroids. The findings were as follows.

- People treated with anti-VEGF were more likely to have improved vision and less swelling at the back of the eye at six months after treatment compared to people who were not treated with anti-VEGF or who were treated with laser or steroids (moderate-certainty evidence).

- In general, there was only very low-certainty evidence on adverse events (harms) comparing anti-VEGF treatment to these other treatments. There were no cases of eye infection (endophthalmitis). There was evidence that people treated with steroids (injected into the eye) were more likely to develop cataract or raised pressure in the eye compared with anti-VEGF.

- Treatment with anti-VEGF was associated with a greater improvement in quality of life (moderate certainty).

How up to date is this review? Cochrane researchers searched for studies that had been published up to June 2019. 


\section{S U M MARY OF FINDINGS}

Summary of findings 1. Anti-VEGF compared to sham for macular oedema secondary to branch retinal vein occlusion

Anti-VEGF v sham for macular oedema secondary to branch retinal vein occlusion

Patient or population: macular oedema secondary to branch retinal vein occlusion

Setting: eye hospital

Intervention: anti-VEGF

Comparison: sham injection

\begin{tabular}{|c|c|c|c|c|c|c|c|}
\hline \multicolumn{2}{|l|}{ Outcomes } & \multicolumn{2}{|c|}{ Anticipated absolute effects ${ }^{\star}(95 \% \mathrm{Cl})$} & \multirow{2}{*}{$\begin{array}{l}\text { Relative ef- } \\
\text { fect } \\
(95 \% \mathrm{CI})\end{array}$} & \multirow{2}{*}{$\begin{array}{l}\text { № of partici- } \\
\text { pants } \\
\text { (studies) }\end{array}$} & \multirow{2}{*}{$\begin{array}{l}\text { Certainty of } \\
\text { the evidence } \\
\text { (GRADE) }\end{array}$} & \multirow[t]{2}{*}{ Comments } \\
\hline & & Risk with sham & Risk with anti-VEGF & & & & \\
\hline \multirow[t]{2}{*}{$\begin{array}{l}\text { Gain of } 15 \text { letters or } \\
\text { more of visual acuity at } 6 \\
\text { months }\end{array}$} & 6 months & 269 per 1000 & $\begin{array}{l}462 \text { per } 1000 \\
(320 \text { to } 669)\end{array}$ & $\begin{array}{l}\text { RR } 1.72 \\
\text { (1.19 to } 2.49)\end{array}$ & $\begin{array}{l}283 \\
(1 \mathrm{RCT})\end{array}$ & $\begin{array}{l}\oplus \oplus \oplus \\
\text { MODERATE } 1\end{array}$ & \\
\hline & 12 months & \multicolumn{5}{|c|}{ Data not available because participants in sham group received anti-VEGF after 6 months } & \\
\hline \multirow[t]{2}{*}{$\begin{array}{l}\text { Mean change in visual } \\
\text { acuity letters at } 6 \text { months } \\
\text { measured with a logMAR } \\
\text { chart (higher letter score } \\
\text { is better visual acuity) }\end{array}$} & 6 months & $\begin{array}{l}\text { The mean VA } \\
\text { change with } \\
\text { sham was } 5 \text { let- } \\
\text { ters }\end{array}$ & $\begin{array}{l}\text { The mean number of letters read } \\
\text { with anti-VEGF was } 7.50 \text { letters } \\
\text { more ( } 5.29 \text { more to } 9.71 \text { more) }\end{array}$ & - & $\begin{array}{l}282 \\
(1 \mathrm{RCT})\end{array}$ & $\begin{array}{l}\oplus \oplus \oplus \\
\text { MODERATE } 1\end{array}$ & \\
\hline & 12 months & \multicolumn{5}{|c|}{ Data not available because participants in sham group received anti-VEGF after 6 months } & \\
\hline \multicolumn{2}{|c|}{$\begin{array}{l}\text { Mean central retinal thickness (CRT) change } \\
\text { at } 6 \text { months in microns (lower value is bet- } \\
\text { ter) }\end{array}$} & $\begin{array}{l}\text { The mean CRT } \\
\text { change with } \\
\text { sham was -207 } \\
\text { microns }\end{array}$ & $\begin{array}{l}\text { The mean CRT with anti-VEGF } \\
\text { was } 57.5 \text { microns less } \\
\text { (108.63 less to } 6.37 \text { less) }\end{array}$ & - & $\begin{array}{l}281 \\
(1 \mathrm{RCT})\end{array}$ & $\begin{array}{l}\oplus \oplus \oplus \\
\text { MODERATE } 1\end{array}$ & \\
\hline \multirow[t]{3}{*}{$\begin{array}{l}\text { Adverse outcomes at any } \\
\text { time point }\end{array}$} & Cataract & 11 per 1000 & 11 per 1000 (1 to 106$)$ & $\begin{array}{l}\text { RR } 0.98(0.09 \\
\text { to } 10.66)\end{array}$ & $283(1 \mathrm{RCT})$ & $\begin{array}{l}\oplus \\
\text { VERY LOW2 }\end{array}$ & \multirow{3}{*}{$\begin{array}{l}12 \text { month re- } \\
\text { sults. Patients } \\
\text { in the sham } \\
\text { arm were able } \\
\text { to receive } \\
\text { rescue an- } \\
\text { ti-VEGF after } 6 \\
\text { months. }\end{array}$} \\
\hline & Raised IOP* & 1 per 1000 & $\begin{array}{l}6 \text { per } 1000 \\
(0 \text { to } 101)\end{array}$ & $\begin{array}{l}\text { RR } 5.41(0.30 \\
\text { to } 96.88)\end{array}$ & $283(1 \mathrm{RCT})$ & $\begin{array}{l}\oplus \\
\text { VERY LOW } 2\end{array}$ & \\
\hline & APTC events & 22 per 1000 & 32 per 1000 ( 6 to 142 ) & $\begin{array}{l}\text { RR } 1.47(0.30 \\
\text { to } 7.14)\end{array}$ & $283(1 \mathrm{RCT})$ & $\begin{array}{l}\oplus \\
\text { VERY LOW2 }\end{array}$ & \\
\hline
\end{tabular}




\begin{tabular}{|c|c|c|c|c|c|c|}
\hline & Endoph- & No endophthal & was reported in either anti-VEGF & $=91)$ arms & & \\
\hline 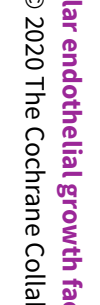 & $\begin{array}{l}\text { Mean change in quality of life (QoL) at } 12 \\
\text { months on the National Eye Institute Visu- } \\
\text { al Functioning Questionnaire-25 (VFQ-25) } \\
\text { (scored } 0 \text { to } 100 \text { ) (higher score is better } \\
\text { quality of life) }\end{array}$ & $\begin{array}{l}\text { The mean QoL } \\
\text { change with } \\
\text { sham was } 0\end{array}$ & $\begin{array}{l}\text { The mean QoL score with an- } \\
\text { ti-VEGF was } 7.60 \text { higher ( } 4.30 \text { to } \\
10.90)\end{array}$ & $281(1 \mathrm{RCT})$ & $\begin{array}{l}\oplus \oplus \oplus \\
\text { MODERATE } 1\end{array}$ & $\begin{array}{l}\text { Data collected } \\
\text { at } 6 \text { months } \\
\text { because par- } \\
\text { ticipants in } \\
\text { sham group } \\
\text { received an- } \\
\text { ti-VEGF after } 6 \\
\text { months }\end{array}$ \\
\hline
\end{tabular}

${ }^{*}$ The risk in the intervention group (and its $95 \% \mathrm{Cl}$ ) is based on the assumed risk in the comparison group and the relative effect of the intervention (and its $95 \% \mathrm{Cl}$ ). Where no events observed in control group, we have used an estimate of 1 per 1000 for illustrative purposes.

ATPC: Antiplatelet Trialists' Collaboration; Cl: Confidence interval; RR: Risk ratio

\section{GRADE Working Group grades of evidence}

High-certainty: We are very confident that the true effect lies close to that of the estimate of the effect

Moderate-certainty: We are moderately confident in the effect estimate: the true effect is likely to be close to the estimate of the effect, but there is a possibility that it is substantially different

Low-certainty: Our confidence in the effect estimate is limited: the true effect may be substantially different from the estimate of the effect

Very low-certainty: We have very little confidence in the effect estimate: the true effect is likely to be substantially different from the estimate of effect

1Downgraded 1 level for risk of bias

2Downgraded 2 levels for imprecision and 1 level for risk of bias

\section{Summary of findings 2. Anti-VEGF compared to laser for branch retinal vein occlusion (BRVO)}

\section{Anti-VEGF compared to laser for branch retinal vein occlusion (BRVO)}

Patient or population: people with BRVO

Setting: eye hospital

Intervention: anti-VEGF

Comparison: laser

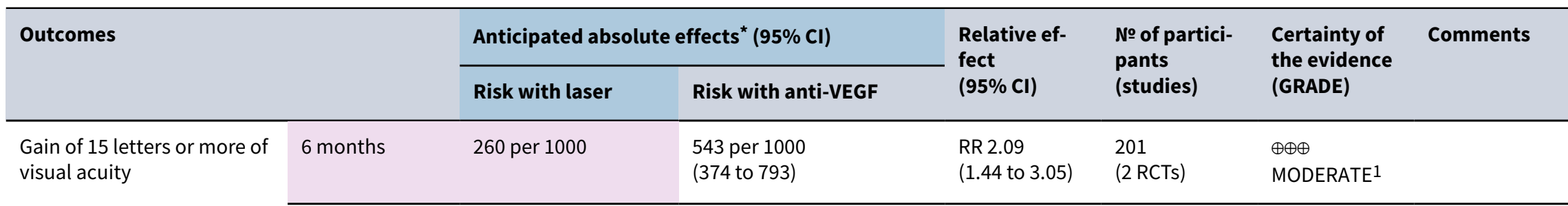




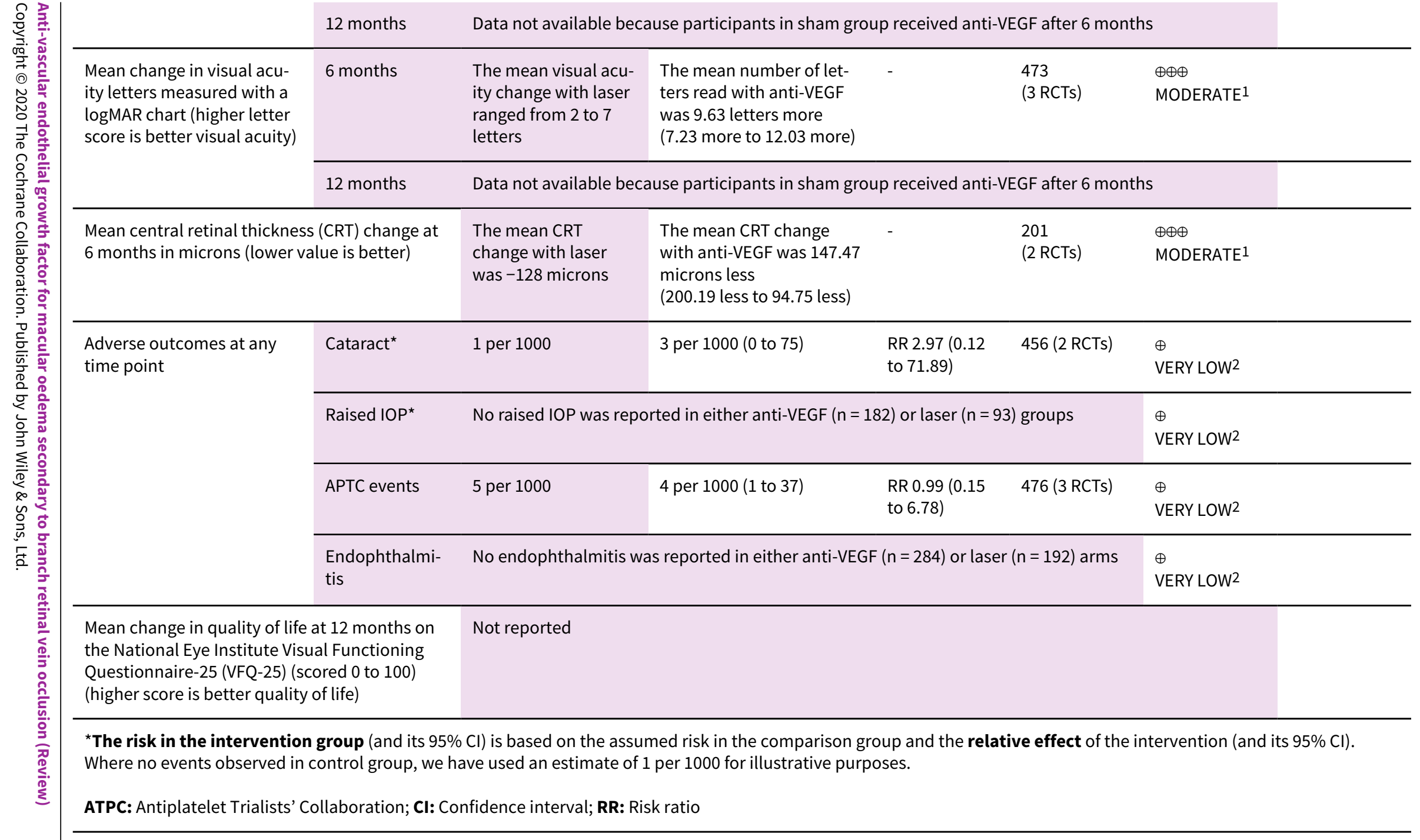

\section{GRADE Working Group grades of evidence}

High-certainty: we are very confident that the true effect lies close to that of the estimate of the effect

Moderate-certainty: we are moderately confident in the effect estimate: the true effect is likely to be close to the estimate of the effect, but there is a possibility that it is substantially different

Low-certainty: our confidence in the effect estimate is limited: the true effect may be substantially different from the estimate of the effect

Very low-certainty: we have very little confidence in the effect estimate: the true effect is likely to be substantially different from the estimate of effect 


\begin{tabular}{|c|c|c|c|c|c|c|c|c|}
\hline \multirow{13}{*}{ 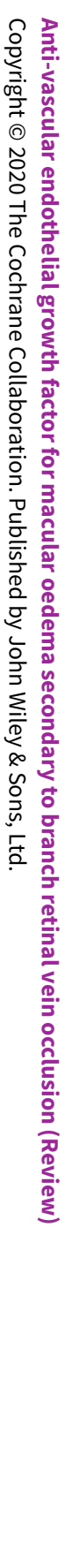 } & \multicolumn{8}{|c|}{$\begin{array}{l}\text { 2Downgraded } 1 \text { level for risk of bias and } 2 \text { levels for imprecision } \\
\text { Summary of findings 3. Anti-VEGF compared to steroid for branch retinal vein occlusion (BRVO) }\end{array}$} \\
\hline & \multicolumn{8}{|c|}{ Anti-VEGF compared to steroid for BRVO } \\
\hline & \multicolumn{8}{|c|}{$\begin{array}{l}\text { Patient or population: people with BRVO } \\
\text { Setting: eye hospital } \\
\text { Intervention: anti-VEGF } \\
\text { Comparison: steroid }\end{array}$} \\
\hline & \multirow{2}{*}{\multicolumn{2}{|c|}{ Outcomes }} & \multicolumn{2}{|c|}{ Anticipated absolute effects ${ }^{\star}(95 \% \mathrm{Cl})$} & \multirow{2}{*}{$\begin{array}{l}\text { Relative ef- } \\
\text { fect } \\
(95 \% \mathrm{CI})\end{array}$} & \multirow{2}{*}{$\begin{array}{l}\text { No of partici- } \\
\text { pants } \\
\text { (studies) }\end{array}$} & \multirow{2}{*}{$\begin{array}{l}\text { Certainty of } \\
\text { the evidence } \\
\text { (GRADE) }\end{array}$} & \multirow[t]{2}{*}{ Comments } \\
\hline & & & Risk with steroid & Risk with anti-VEGF & & & & \\
\hline & \multirow{2}{*}{$\begin{array}{l}\text { Gain of } 15 \text { letters or } \\
\text { more of visual acu- } \\
\text { ity }\end{array}$} & $\begin{array}{l}6 \\
\text { months }\end{array}$ & 379 per 1000 & $\begin{array}{l}633 \text { per } 1000 \\
\text { (466 to } 802 \text { ) }\end{array}$ & $\begin{array}{l}\text { RR } 1.67 \\
\text { (1.33 to } 2.10)\end{array}$ & $\begin{array}{l}330 \\
(2 \mathrm{RCTs})\end{array}$ & $\begin{array}{l}\oplus \oplus \oplus \oplus \\
\mathrm{HIGH}\end{array}$ & \\
\hline & & $\begin{array}{l}12 \\
\text { months }\end{array}$ & 338 per 1000 & $\begin{array}{l}595 \text { per } 1000 \\
(460 \text { to } 771)\end{array}$ & $\begin{array}{l}\text { RR } 1.76 \\
(1.36 \text { to } 2.28)\end{array}$ & $\begin{array}{l}307 \\
(1 \mathrm{RCT})\end{array}$ & $\begin{array}{l}\oplus \oplus \oplus \oplus \\
\mathrm{HIGH}\end{array}$ & \\
\hline & \multirow{2}{*}{$\begin{array}{l}\text { Mean change in vi- } \\
\text { sual acuity letters } \\
\text { measured with a } \\
\text { logMAR chart (high- } \\
\text { er letter score is } \\
\text { better visual acu- } \\
\text { ity) }\end{array}$} & $\begin{array}{l}6 \\
\text { months }\end{array}$ & $\begin{array}{l}\text { The mean visual acu- } \\
\text { ity change with steroid } \\
\text { ranged from } 9 \text { to } 11 \text { let- } \\
\text { ters }\end{array}$ & $\begin{array}{l}\text { The mean number of letters read with } \\
\text { anti-VEGF was } 8.22 \text { more } \\
\text { ( } 5.69 \text { more to } 10.76 \text { more) }\end{array}$ & - & $\begin{array}{l}330 \\
(2 \text { RCTs) }\end{array}$ & $\begin{array}{l}\oplus \oplus \oplus \oplus \\
\mathrm{HIGH}\end{array}$ & \\
\hline & & $\begin{array}{l}12 \\
\text { months }\end{array}$ & $\begin{array}{l}\text { The mean visual acu- } \\
\text { ity change with steroid } \\
\text { ranged from } 6 \text { to } 8 \text { let- } \\
\text { ters }\end{array}$ & $\begin{array}{l}\text { The mean number of letters read with } \\
\text { anti-VEGF was on average } 9.15 \text { letters } \\
\text { more ( } 6.32 \text { more to } 11.97 \text { more) }\end{array}$ & - & $\begin{array}{l}343 \\
(2 \mathrm{RCTs})\end{array}$ & $\begin{array}{l}\oplus \oplus \oplus \oplus \\
\mathrm{HIGH}\end{array}$ & \\
\hline & \multicolumn{2}{|c|}{$\begin{array}{l}\text { Mean central retinal thickness } \\
\text { (CRT) change at } 12 \text { months in } \\
\text { microns (lower value is better) }\end{array}$} & $\begin{array}{l}\text { The mean CRT change } \\
\text { with steroid ranged from } \\
-249 \text { to }-306 \text { microns }\end{array}$ & $\begin{array}{l}\text { The mean CRT change with anti-VEGF } \\
\text { was } 26.92 \text { microns less } \\
\text { (65.88 less to } 12.04 \text { less) }\end{array}$ & - & $\begin{array}{l}343 \\
(2 \text { RCTs })\end{array}$ & $\begin{array}{l}\oplus \oplus \oplus \\
\text { MODERATE } 2\end{array}$ & \\
\hline & \multirow[t]{3}{*}{$\begin{array}{l}\text { Adverse outcomes } \\
\text { at any time point }\end{array}$} & Cataract & 125 per 1000 & 22 per 1000 ( 7 to 75$)$ & $\begin{array}{l}\text { RR } 0.12(0.04 \\
\text { to } 0.32)\end{array}$ & 551 (3 RCTs) & $\begin{array}{l}\oplus \oplus \oplus \\
\text { MODERATE } 2\end{array}$ & \\
\hline & & $\begin{array}{l}\text { Raised } \\
\text { IOP }\end{array}$ & 240 per 1000 & 57 per 1000 (34 to 94$)$ & $\begin{array}{l}\mathrm{RR} 0.25(0.16 \\
\text { to } 0.40)\end{array}$ & 673 (4 RCTs) & $\begin{array}{l}\oplus \oplus \oplus \\
\text { MODERATE2 }\end{array}$ & \\
\hline & & $\begin{array}{l}\text { APTC } \\
\text { events }\end{array}$ & 1 per 1000 & 3 per 1000 (0 to 74$)$ & $\begin{array}{l}\text { RR } 3.02(0.12 \\
\text { to } 73.55)\end{array}$ & 587 (3 RCTs) & $\oplus$ & \\
\hline
\end{tabular}




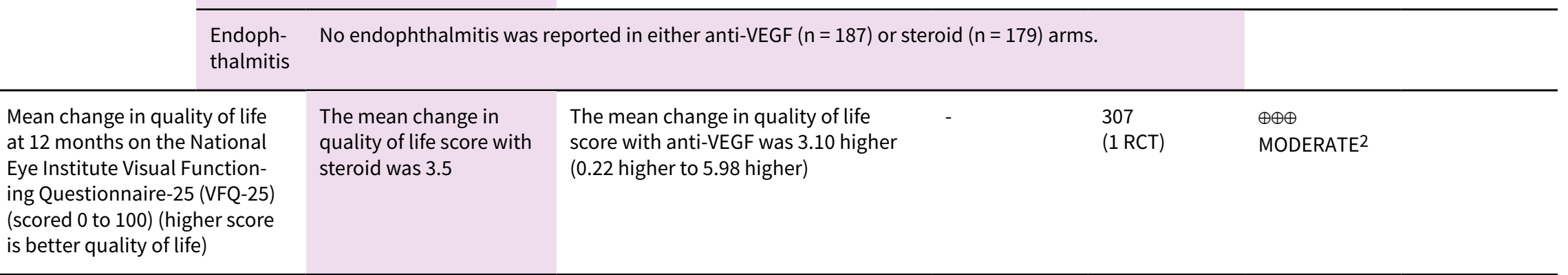

*The risk in the intervention group (and its $95 \% \mathrm{Cl}$ ) is based on the assumed risk in the comparison group and the relative effect of the intervention (and its $95 \% \mathrm{Cl}$ ).

ATPC: Antiplatelet Trialists' Collaboration; Cl: Confidence interval; RR: Risk ratio

\section{GRADE Working Group grades of evidence}

High-certainty: we are very confident that the true effect lies close to that of the estimate of the effect

Moderate-certainty: we are moderately confident in the effect estimate: the true effect is likely to be close to the estimate of the effect, but there is a possibility that it is substantially different

Low-certainty: our confidence in the effect estimate is limited: the true effect may be substantially different from the estimate of the effect

Very low-certainty: we have very little confidence in the effect estimate: the true effect is likely to be substantially different from the estimate of effect

1 One study was judged to be at high risk of attrition bias because participants in the steroid group dropped out of the study due to adverse effects and poor response. We did not downgrade for risk of bias as the direction of the risk of bias is likely to be favouring the steroid group and so the estimate of effect reported here may well be an under-estimate.

2Downgraded 1 level for risk of bias (studies were at high risk of attrition bias)

3Downgraded 2 levels for imprecision and 1 level for risk of bias 


\section{B A C K G R O U N D}

\section{Description of the condition}

Branch retinal vein occlusion (BRVO) is the second most commonly occurring retinal vascular abnormality after diabetic retinopathy (Mitchell 1996). A BRVO is an occlusion of either a major branch retinal vein draining one quadrant of the retina, a macular branch vein draining the macula, or a peripheral branch vein draining a portion of the retinal periphery. The pathogenesis of BRVO is thought to involve both retinal vein compression and damage to the vessel wall, possibly leading to thrombus formation. BRVOs are thought to occur at sites where retinal arterioles cross retinal veins. Histopathological studies support the hypothesis that because of a common adventitial sheath, thickening of the arteriolar wall compresses the lumen of the vein which alters blood flow causing thrombosis and venous occlusion (Frangieh 1982). Once the occlusion occurs, increased vascular pressure behind the occlusion may lead to leakage of fluid and small molecules across the vascular wall and into the surrounding retinal tissue, resulting in local oedema. This oedema is characterised by the collection of fluid in intercellular spaces within the outer plexiform layer of the retina and results from the breakdown of the capillary endothelium blood-retinal barrier and leakage of fluid from the vasculature. Vascular endothelial damage to the affected vein may induce low-grade, chronic inflammation of the retinal microvasculature and upregulation of inflammatory mediators. These mediators include prostaglandins, leukotrienes, intercellular adhesion molecule-1, integrins, tumour necrosis factor-a, and vascular endothelial growth factor (VEGF) (Ehlers 2011; Funk 2009; Rehak 2008).

The 15-year incidence of BRVO in an elderly (aged 65 to 74 years) Caucasian (understood to be white) population is $1.8 \%$ (Klein 2008); and most studies report a range of between $0.6 \%$ and $2 \%$ (Klein 2000; Mitchell 1996; Wong 2005; Xu 2007; Yasuda 2010). A recent pooled analysis of 68,751 individuals indicates an age and gender standardised prevalence for BRVO of 4.42 per 1000 (confidence interval (Cl) 3.65 to 5.19; Rogers 2010a); however, significant heterogeneity between studies precluded a formal meta-analysis. Second eye involvement by BRVO may occur in between 3.5\% to $9 \%$ of cases over time (Glacet-Bernard 1996; Rogers 2010b); and affected individuals have a loss in vision-related quality of life even with normal vision in the fellow eye (Awdeh 2010).

BRVO may be classified on a spectrum of ischaemic or nonischaemic designated by the disc areas (DA) of hypoperfusion on fluorescein angiography. The extent of ischaemia has a relationship with the likelihood of neovascular complications with reports suggesting a rate of retinal neovascularisation in $36 \%$ to $62 \%$ of eyes with more than 5 DA of non-perfusion over two years of follow-up (Shilling 1976).

Known risk factors for BRVO include hypertension, atherosclerosis, hyperlipidaemia, diabetes mellitus, thrombophilia and other inflammatory and myeloproliferative disorders (Dodson 1982; Dodson 1992; EDCCS Group 1993). A systematic review of the natural history of BRVO suggests that although the baseline visual acuity (VA) is generally poor (less than 20/40), with time the VA improves, and between one third and three quarters of eyes show at least a two-line improvement in VA without intervention. However, clinically significant improvement beyond 20/40 is uncommon (Rogers 2010b).
The most common cause of visual loss in BRVO patients is macular oedema (MO), which occurs in $5 \%$ to $15 \%$ of patients within the first year (Rogers 2010b). Other causes of visual loss include macular ischaemia, glaucoma and neovascularisation (Rogers 2010b). Macular oedema and neovascularisation of the retina or disc are the two major complications that require therapy (BVOS Group 1984; Shilling 1976). Many treatment strategies, both medical and surgical, have been reported for BRVO. Surgical treatments thought to be of benefit include vitrectomy with internal limiting membrane peeling and vitrectomy with arteriovenous sheathotomy (Ehlers 2011). Medical therapies of clinical benefit include grid laser photocoagulation (GLP), sector panretinal photocoagulation, intravitreal steroids (triamcinolone, dexamethasone) and intravitreal vascular endothelial growth factor inhibitors.

The BVOS clinical trial evaluated whether grid macular laser photocoagulation improved the VA in patients with a VA of 20/40 or worse resulting from MO secondary to BRVO. This multicentre randomised controlled trial (RCT) assigned 139 participants to either grid macular laser photocoagulation or no laser treatment. The groups were well matched at baseline in terms of risk factors, duration of symptoms, and VA. With a mean follow-up of 3.1 years (68\% of participants), the grid laser group had statistically significant improvements in VA with 65\% (28/43) treated versus $37 \%(13 / 35)$ controls gaining two or more lines of vision over consecutive visits $(P=0.014)$. Since its publication in 1984 , this has been the 'gold standard' treatment; there were, however, several limitations, notably the exclusion of participants who had a BRVO within three months and the exclusion of those with foveal haemorrhage (BVOS Group 1984). This study has led to the current recommendation in the UK (Royal College of Ophthalmologists) that GLP is an effective treatment to reduce MO and to improve VA in BRVO with MO and VA of 20/40 or less. Treatment should be postponed for three months after onset to allow for any spontaneous resolution and reduction in haemorrhage. Fluorescein angiography is recommended before treatment to quantify the level of macular ischaemia, which may limit the value of laser photocoagulation. In addition, grid laser treatment is thought unlikely to provide significant benefit in eyes with BRVO of more than one year's duration and VA of $20 / 200$ or worse.

The SCORE study (Scott 2009) examined intravitreal triamcinolone (IVTA) versus standard of care (GLP) to elucidate the differences in GLP versus IVTA for MO secondary to BRVO in 411 eyes. Approximately $45 \%$ of individuals had a BRVO with MO of three to six months' duration and $9 \%$ of included participants had more than 10 disc areas of non-perfusion. The mean (standard deviation (SD)) number baseline Early Treatment in Diabetic Retinopathy Study (ETDRS) letters was 57 (12.6). Eyes were randomised to either grid-pattern laser ( $n=137), 1$ mg IVTA $(n=136)$, or 4 mg IVTA $(n=138)$. In the SCORE study, eyes were retreated with their assigned dose of IVTA or grid-pattern laser every four months during the study period unless there was a predefined significant improvement or a significant adverse event. The results of the SCORE study demonstrated that there was no difference in VA between eyes treated with IVTA or GLP at 12 months. Twenty-nine per cent, $26 \%$, and $27 \%$ gained three or more lines of visual acuity at one year in the laser, $1 \mathrm{mg}$, and $4 \mathrm{mg}$ groups, respectively. All three groups showed similar reductions in $\mathrm{MO}$ as measured by optical coherence tomography (OCT). The IVTA groups had an increased 
rate of side effects, particularly raised intraocular pressure (IOP) requiring medication (7\%: $1 \mathrm{mg}$; $41 \%$; $4 \mathrm{mg}$; versus $2 \%$ laser) and cataract formation (25\%: $1 \mathrm{mg}$; 35\%: $4 \mathrm{mg}$; versus $13 \%$ laser). There were no cases of endophthalmitis in the laser and $1 \mathrm{mg}$ group, but there was one case in the $4 \mathrm{mg}$ group. Other reported adverse events were vitreous floaters and conjunctival haemorrhage: $31 \%$ of the $1 \mathrm{mg}$ triamcinolone group and $26 \%$ of $4 \mathrm{mg}$ triamcinolone group had vitreous floaters and $30 \%$ of the $1 \mathrm{mg}$ triamcinolone group and $33 \%$ of the $4 \mathrm{mg}$ triamcinolone group had conjunctival haemorrhage.

Recently, the utility of extended-release corticosteroid delivery systems has been evaluated in the GENEVA study (Haller 2010). An international study at 167 sites in 24 countries was designed to examine the effect of a sustained-release intravitreal dexamethasone delivery system at the $0.35 \mathrm{mg}$ and $0.7 \mathrm{mg}$ (Ozurdex, Allergan) dose for MO in eyes with BRVO or central retinal vein occlusion (CRVO) over a 6 -month period. At baseline, the mean VA was approximately 54 letters (20/80) in all groups, and the mean central retinal thickness was approximately 550 microns. Ten per cent of participants $(131 / 1267)$ had a history of photocoagulation, and $17 \%$ had a duration of retinal vein occlusion (RVO) and MO of less than three months. All comparison groups were well matched. Primary outcome was reported for all RVO eyes grouped together. In a subgroup analysis of 291 eyes with BRVO receiving the 0.7 $\mathrm{mg}$ implant, at 60 days following treatment $30 \%$ gained 15 letters or more compared to $13 \%$ in the sham group. At 90 days, $24 \%$ gained 15 letters or more compared to $15 \%$ in the sham group. The difference was significant at both time points, but not at the 180day time point. The overall incidence of ocular adverse events was significantly higher in the Ozudex implant $0.7 \mathrm{mg}$ group (62.9\%) and Ozudex implant $0.35 \mathrm{mg}$ group (61.9\%) than in the sham group $(42.8 \%)$. Cataract progression was similar in both the treatment and the sham groups in the 6-month study. The only adverse events that occurred significantly more frequently in either the Ozudex implant treatment group than in the sham group were eye pain, ocular hypertension, and anterior chamber cells. Ocular hypertension ( $\geq 25 \mathrm{mmHg}$ ) occurred in $4 \%$ of treated eyes $(0.35 \mathrm{mg}$ and $0.7 \mathrm{mg}$ implants) compared to $0.7 \%$ of sham eyes (Haller 2010). Ozurdex received Food and Drug Administration (FDA) approval for treatment of MO secondary to BRVO in 2009.

\section{Description of the intervention}

Vascular endothelial growth factor (VEGF) plays a role in the development of $\mathrm{MO}$ and in the neovascular complications of BRVO. Elevated intraocular levels of VEGF have been demonstrated in patients with RVOs (Campochiaro 2008); and sustained release of VEGF in primate eyes causes vascular leakage and MO (Ozaki 1997). There are several anti-VEGF agents available. The first licensed drug was bevacizumab (Avastin ${ }^{\circledR}$ ), a recombinant humanised monoclonal whole immunoglobulin antibody that binds to VEGF and blocks the binding of VEGF to endothelial cell receptors (Ferrara 2006). Bevacizumab was licensed for the treatment of bowel cancer. Pegaptanib sodium (Macugen ${ }^{\circledR}$ ) is a pegylated modified oligonucleotide, which binds to extracellular VEGF-165 and antagonises its biological effects (Gragoudas 2004). Ranibizumab (Lucentis ${ }^{\circledR}$ ) is a recombinant humanised monoclonal immunoglobulin antibody fragment that binds to the receptors of biologically active VEGF-A (Presta 1997); it has been licensed for the treatment of age-related macular degeneration (AMD) and RVOs in the USA and Europe. Aflibercept (VEGF Trap-eye)
(Eylea ${ }^{\circledR}$ ) is a further VEGF-binding recombinant fusion protein, and has been hypothesised to have the greatest efficacy of its class due to its binding to VEGF isoforms $A$ and $B$, as well as placental growth factor (PGF). Monoclonal antibodies against VEGF administered intravitreally have been approved for the treatment of AMD (Rosenfeld 2006), and widespread evidence has suggested a benefit and favourable side effect profile of their use in MO secondary to RVOs (Campochiaro 2010b; Prager 2009, GarnockJones 2011).

\section{How the intervention might work}

Elevated intraocular levels of VEGF have been demonstrated in patients with RVOs (Noma 2006). Sustained release of VEGF in primate eyes causes vascular leakage and MO (Ozaki 1997); and several studies have demonstrated that anti-VEGF antibodies inhibit VEGF mediated neovascularisation and permeability in both in vitro and in vivo studies (Aiello 1995a; Aiello 1995b; Boyd 2002). Thus there is a strong basis for the hypothesis that anti-VEGF agents may be beneficial in the treatment of vascular leakage and MO (Campochiaro 2008).

\section{Why it is important to do this review}

BRVO is the most common RVO and a significant cause of visual morbidity. Current treatment regimens licensed in the UK include macular photocoagulation and more recently intravitreal dexamethasone (Ozurdex $\left.{ }^{\circledR}\right)$ implants. Intravitreal antiVEGF therapy has a good side effect profile (serious adverse ocular events less than $0.1 \%$ (out of 1301 participants)) (Kourlas 2007) (see systematic review Mitchell 2011) and has not been found to be associated commonly with side effects such as a sustained rise in IOP commonly seen with steroid preparations. Several early reports suggested an important clinical efficacy for the use of anti-VEGF in MO secondary to BRVO (Campochiaro 2010b; Campochiaro 2010a; Kriechbaum 2008; Moradian 2011; Prager 2009; Rabena 2007).

\section{OB JECTIVES}

To investigate the efficacy and gather evidence from randomised controlled trials (RCTs) on the potential harms of anti-vascular endothelial growth factor (VEGF) agents for the treatment of macular oedema (MO) secondary to branch retinal vein occlusion (BRVO).

\section{METHODS}

\section{Criteria for considering studies for this review}

\section{Types of studies}

In this review, we sought to include all randomised controlled trials of at least six months' duration: we judged a minimum of six months was required to determine treatment efficacy and adverse effects. We included published and unpublished studies in all languages to ensure the widest possible collection of evidence. We included studies as long as they reported at least one primary or secondary outcome that this review is considering.

\section{Types of participants}

We included trials with participants of all ages and both genders who have had a diagnosis of unilateral or bilateral macular oedema secondary to branch retinal vein occlusion or hemi-retinal vein occlusion. All countries and ethnic groups were eligible for 
inclusion. We included treatment-naive and previously-treated eyes.

\section{Types of interventions}

We included trials where anti-VEGF treatment was compared with another treatment, no treatment, or placebo. We excluded trials where combination treatments (anti-VEGF plus other treatments) were used and excluded trials that investigated the dose and duration of treatment without a comparison group (other treatment/no treatment/sham). We judged that choosing clear, distinct comparisons would help produce clear results of treatment outcome.

\section{Types of outcome measures}

\section{Primary outcomes}

The primary outcome for this review was the proportion of participants with an improvement from baseline in best-corrected visual acuity (BCVA) of greater than or equal to 15 letters (three lines) on the Early Treatment in Diabetic Retinopathy Study (ETDRS) chart at six months and at 12 months of follow-up.

\section{Secondary outcomes}

We examined the following secondary outcomes as they represent important clinical and therapeutic indices of safety and efficacy.

1. Mean visual acuity (VA) change at six and 12 months.

2. The proportion of participants with a loss of 15 or more letters (ETDRS) compared with baseline at six and 12 months.

3. Change in central retinal thickness (CRT) on optical coherence tomography (OCT) from baseline at 12 months.

\section{Adverse outcomes}

We sought to report any ocular or systemic adverse outcomes reported in the trials.

\section{Quality of life data}

We reported any quality of life data reported in the studies.

\section{Search methods for identification of studies}

\section{Electronic searches}

The Cochrane Eyes and Vision Information Specialist conducted systematic searches in the following electronic databases for RCTs and controlled clinical trials. There were no restrictions to language or year of publication. The date of the search was 12 June 2019.

- Cochrane Central Register of Controlled Trials (CENTRAL; 2019, Issue 6) (which contains the Cochrane Eyes and Vision Trials Register) in the Cochrane Library (searched 12 June 2019) (Appendix 1).

- MEDLINE Ovid (1946 to 12 June 2019) (Appendix 2)

- Embase Ovid (1980 to 12 June 2019) (Appendix 3).

- Latin American and Caribbean Literature on Health Sciences (LILACS) (1982 to 12 June 2019) (Appendix 4).

- ISRCTN registry (www.isrctn.com/editAdvancedSearch; searched 12 June 2019) (Appendix 5).

- US National Institutes of Health Ongoing Trials Register (www.ClinicalTrials.gov; searched 12 June 2019) (Appendix 6).
- World Health Organization (WHO) International Clinical Trials Registry Platform (ICTRP) (www.who.int/ictrp; searched 12 June 2019) (Appendix 7)

\section{Searching other resources}

We manually searched the references of identified studies to try to find other relevant studies. We also contacted the corresponding authors of included studies to find further information.

\section{Data collection and analysis}

\section{Selection of studies}

Two review authors independently reviewed all the titles and abstracts identified from the electronic and manual searches against the inclusion criteria. We classified each report into one of four categories: include; possibly include; exclude; and unclear. We obtained the full-text articles of all 'possibly include' articles and both review authors independently assessed and classified these articles. We resolved disagreement by discussion between the review authors.

\section{Data extraction and management}

We extracted the following participant and trial characteristics and reported them in appropriate table format.

- Participant characteristics (gender, age, diagnostic criteria, baseline VA, central retinal thickness)

- Intervention (drug, dose, timing interval, time from diagnosis, frequency and length of treatment)

- Methodology (group size, randomisation, masking, unit of analysis)

- Primary and secondary outcomes

- Additional data (quality of life)

- Treatment compliance and dropout rate/loss to follow-up

Two review authors extracted the data independently using forms developed by the Cochrane Eyes and Vision Group. The review authors compared the two sets of extracted data and resolved any identified discrepancies through discussion. One review author entered data into Review Manager 5 (RevMan 5) and a second review author checked that the data entered were correct (Review Manager 2014). Where more than one report was present for a single study, we used all reports to extract data into a single data collection form.

When data were missing from a publication or ClinicalTrials.gov, we contacted investigators by email with a request to provide data for this review. We used intention-to-treat analysis to deal with missing data.

\section{Assessment of risk of bias in included studies}

Two review authors assessed the methodological quality of the selected trials according to Chapter 8 of the Cochrane Handbook for Systematic Reviews of Interventions (Higgins 2019). We considered the following main criteria according to the GRADE approach.

- Selection bias: sequence generation, allocation concealment

- Detection bias: blinding (masking) of outcome assessment

- Performance bias: masking of participants, researchers and outcome assessors 
- Attrition bias: loss to follow-up, rates of compliance

- Reporting bias: selective outcome reporting

We reported each parameter as high risk of bias, low risk of bias or unclear.

\section{Measures of treatment effect}

We defined these according to the data types established in Chapter 9 of the Cochrane Handbook for Systematic Reviews of Interventions (Deeks 2017); they include the following.

\section{Dichotomous data}

Variables in this group included the primary outcome, the proportion of participants with a loss of 15 or more letters (ETDRS) compared with baseline, the proportion of participants experiencing a complication or adverse event during follow-up and the proportion of participants given additional treatments during follow-up. We reported dichotomous variables as risk ratios (RRs) with $95 \%$ confidence intervals (Cls).

\section{Continuous data}

These variables included mean change in visual acuity (VA) and mean change in central retinal thickness (CRT). We reported continuous variables as a mean difference (MD) \pm standard deviation (SD) (normal distribution) or median and inter-quartile range (not normally distributed).

\section{Ordinal data}

The types of adverse events, complications and interventions performed were ordinal data.

\section{Counts and rates data}

We measured the number of adverse events, number of complications and interventions performed as counts or rates data.

\section{Unit of analysis issues}

All studies considered one eye per person. When dealing with multiarm studies, we only extracted data from the arms dealing with the basis of this review.

\section{Dealing with missing data}

We contacted the authors of the VIBRANT study to request SD data for mean letters gained and mean change in central retinal thickness at six months. This was provided. We contacted the authors of unpublished and unreported studies NCT01189526 and NCT01795209 to obtain results but did not receive responses to our email requests.

\section{Assessment of heterogeneity}

We considered heterogeneity between studies by looking at the basic characteristics of participants (e.g. age, gender or ethnicity) as well as their inclusion and exclusion criteria. We used the $I^{2}$ statistic to assess heterogeneity. This is a measure of the percentage variance attributable to study heterogeneity.

\section{Assessment of reporting biases}

We assessed reporting bias by comparing the published results against the study protocol. We assessed publication bias by searching both published articles and trial registries.

\section{Data synthesis}

We used RevMan 5 to combine results across studies. We used GRADE software to produce 'Summary of findings' tables, along with certainty assessments, which we used to summarise risk of bias in presented results.

\section{Subgroup analysis and investigation of heterogeneity}

We performed subgroup analysis by comparing the efficacy of the anti-VEGF agents (bevacizumab, ranibizumab and aflibercept) across studies.

We assessed heterogeneity between studies with the $\mathrm{I}^{2}$ statistic as outlined in Assessment of heterogeneity above.

\section{Sensitivity analysis}

No sensitivity analysis was performed for this review.

\section{'Summary of findings' table}

We prepared 'Summary of findings' tables for the following three comparisons using GRADEpro software (GRADEpro GDT): anti-VEGF versus sham, anti-VEGF versus laser and anti-VEGF versus steroids. We included the following outcomes in the 'Summary of findings' table.

1. Gain of 15 letters or more of visual acuity at six months

2. Gain of 15 letters or more of visual acuity at 12 months

3. Mean visual acuity change at six months

4. Mean visual acuity change at 12 months

5. Mean central retinal thickness change at 12 months

6. Adverse outcomes at any time point

7. Quality of life change at 12 months

We graded the certainty of the evidence using GRADE (GRADE 2013). GRADE has four categories: high-, moderate-, low- and very low-certainty evidence. We considered randomised controlled trials to be high-certainty evidence and downgraded for serious limitations in study design (risk of bias), inconsistency, imprecision, indirectness and evidence of publication bias. Two authors did the GRADE assessment independently using a checklist designed to aid consistency and reproducibility of the GRADE assessments (Meander 2014).

\section{RE S U L T S}

\section{Description of studies}

\section{Results of the search}

The electronic searches run in 2012 yielded a total of 448 references. The Cochrane Information Specialist (CIS) scanned the search results, removed duplicates and 325 references which were not relevant to the scope of the review. We screened 163 reports to identify potentially relevant studies. We identified 29 case series and summarised the results of these studies (see Table 1). We excluded a further 121 records after reading the abstract. We obtained full-text copies of eight records for further investigation. We included two studies in the review. One RCT (two reports) compared anti-VEGF with sham injection; and one quasi-RCT compared macular grid laser with anti-VEGF. We excluded five studies and identified five ongoing studies (EUCTR2010-023900-29GB; NCT01189526; NCT01396057; NCT01521559; NCT01635803). We 
marked these studies for assessment and possible inclusion in the review when data became available.

Update searches run in June 2019 yielded a further 1735 records (Figure 1). After 538 duplicates were removed, the Cochrane Information Specialist (CIS) screened the remaining 1197 records and removed 710 references that were not relevant to the scope of the review. We screened the remaining 487 references and obtained 35 full-text reports for further assessment. We identified 13 reports of eight new studies; for further details see Characteristics of included studies. We excluded 21 reports of 21 studies: see Characteristics of excluded studies. We identified one new ongoing study (NCT03108352); and have followed up on the five ongoing studies that were cited in the previous version of the review. Studies NCT01189526 and NCT01635803 are ongoing; the three other studies have been completed and incorporated into the following new studies: Bandello 2018, COMRADE-B and VIBRANT. 
Figure 1. Study flow diagram.

2 included studies and 5 ongoing studies in previous version of this review (searches as of August 2012)

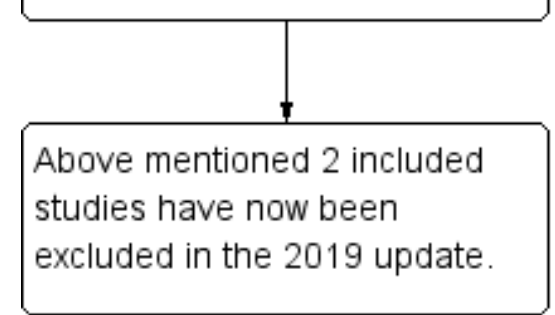

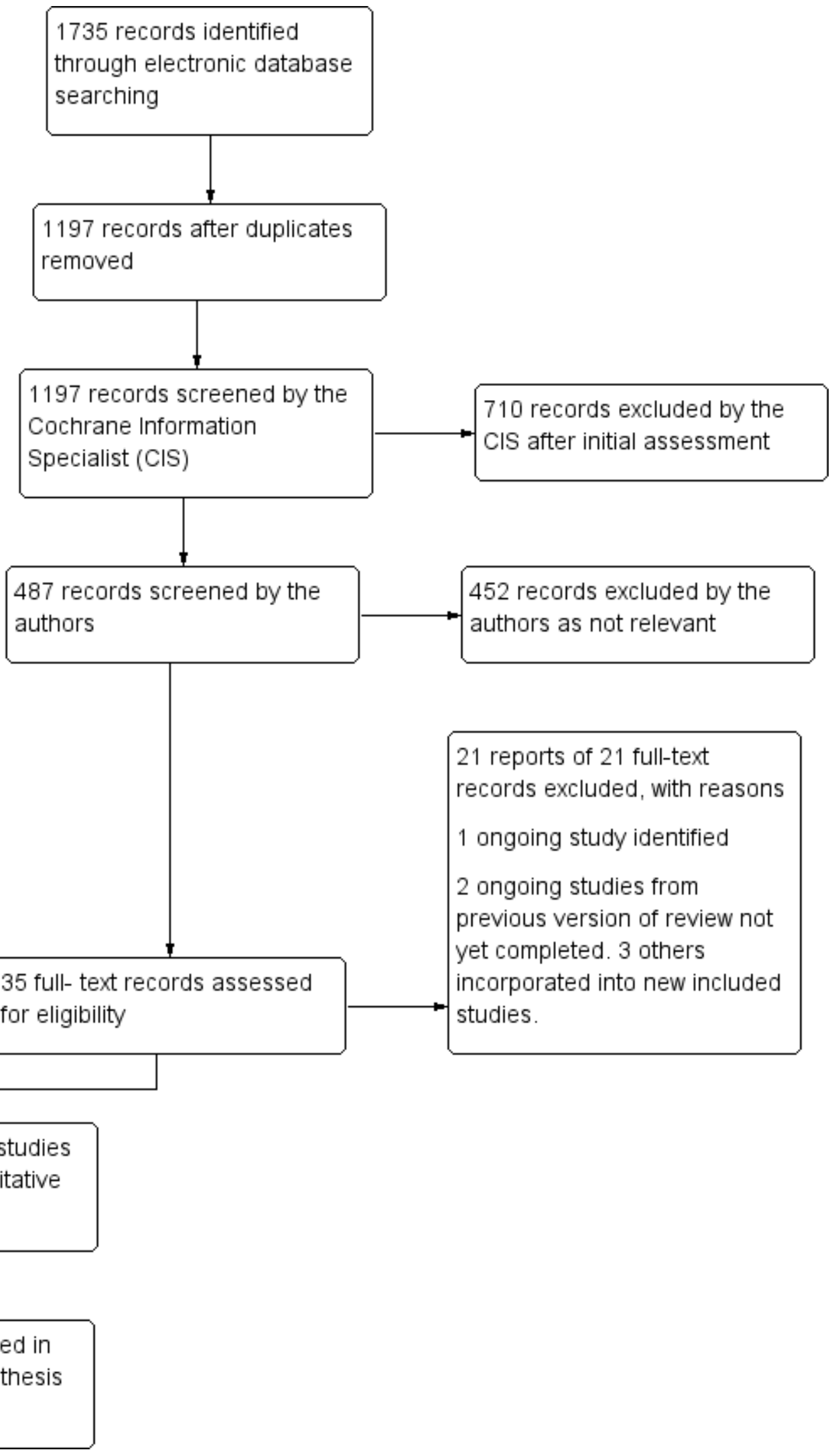


In the previous version of this review there were two included studies and five excluded studies. For this update we have excluded the two studies which were previously included; see Differences between protocol and review. Consequently this review now contains eight included studies, 26 excluded studies and three ongoing studies.

\section{Included studies}

Bandello 2018 was a 12-month multi-centre randomised controlled trial of 307 eyes in 307 participants with branch retinal vein occlusion. Participants were randomised to dexamethasone implant $(n=154)$ or ranibizumab injection $(n=153)$. Eyes in the dexamethasone arm all received treatment at baseline, then again at month 5 and month 10/11 if required. Eyes in the ranibizumab group received injection at baseline then monthly to month 5 , with treatment as required thereafter to month 12 .

BLOSSOM was a 12-month, phase III, multicentre randomised controlled trial of 283 participants with branch retinal vein occlusion. Participants were randomised to receive ranibizumab ( $n=190)$ or sham $(n=93)$. The ranibizumab arm received three ranibizumab $0.5 \mathrm{mg}$ injections spaced monthly, followed by injections as required based on pre-defined re-treatment criteria. The sham arm consisted of treatment in the form of sham injections until six months, after which participants could receive ranibizumab $0.5 \mathrm{mg}$ as required. Hence we excluded data points from this arm from six months.

BRIGHTER was a phase III open label study of 455 participants across 17 countries comparing ranibizumab $(n=183)$, ranibizumab plus laser $(n=180)$, and laser alone $(n=92)$ for the treatment of cystoid macular oedema in BRVO. Participants were assigned with a ratio of 2:2:1 to these groups. Participants received monthly injection or laser every four months until visual acuity was deemed stable, after which treatment was given on an 'as needed' basis. Importantly, participants in the laser arm were also able to receive ranibizumab from month 6 . We excluded data points from this arm from six months onwards.

COMRADE-B was a 6-month, phase IIIb, multicentre, randomised, double-masked study that enrolled participants with visual impairment due to macular oedema secondary to BRVO. Two hundred and forty-four participants were enrolled from 74 sites across Europe. Ranibizumab $(n=126)$ was given as three loading injections at the start of the study until a stable VA was reached followed by 'as needed' treatment; whilst the dexamethasone arm $(n=118)$ was given as a single injection at baseline with monthly sham injections until month 3 followed by an 'as needed' regimen. The primary outcome was mean average change in BCVA from baseline to month 1 through month 6 .

Higashiyama 2013 performed a prospective, comparative, randomised, interventional clinical trial. Forty-three eyes of 43 participants with macular oedema because of BRVO were randomly assigned to $4 \mathrm{mg}$ intravitreal injections of TA (IVTA) (21 participants, IVTA group) or $1.25 \mathrm{mg}$ intravitreal injections of bevacizumab (IVB) (22 participants, IVB group) and followed for 12 months. No additional treatments were administered for three months after the initial injection; additional injections were administered when macular oedema recurred between three and 12 months after the initial injection. The main outcome measures were changes in the logarithm of the minimal angle of resolution BCVA and CRT from baseline to 12 months.

The RABAMES trial was a prospective, randomised, controlled, multicentre investigator-initiated clinical trial over six months on 30 participants with BRVO and macular oedema. The three arms of the study were: intravitreal ranibizumab $(n=10)$ versus grid-pattern laser photocoagulation $(n=10)$ versus a combination of both ( $n$ $=10$ ) in participants with chronic macular oedema secondary to BRVO. During the 3-month treatment period, participants received either three monthly intravitreal ranibizumab injections, or up to two treatment sessions of macular laser photocoagulation or intravitreal ranibizumab combined with laser photocoagulation. The primary outcomes were mean gain in ETDRS letters, proportion of participants gaining 15 or more letters and improvement in central retinal thickness.

Ramezani 2012 performed a controlled, randomised single-masked clinical trial on treatment-naive BRVO with duration of less than 12 weeks. Eligible eyes were randomly assigned to intravitreal bevacizumab (IVB) ( $n=43$ ) and intravitreal triamcinolone (IVT) $(n=$ 43) groups. In the IVB group, the eyes received three prescheduled monthly intravitreal injections of $1.25 \mathrm{mg} / 0.5 \mathrm{ml}$ bevacizumab. The eyes in the IVT group had two prescheduled intravitreal injections of $2 \mathrm{mg} / 0.5 \mathrm{ml}$ triamcinolone acetonide, performed two months apart. The primary outcome was the change in BCVA at six months. Secondary outcome measures consisted of CMT changes, determined by OCT, and intraocular pressure (IOP) changes.

The VIBRANT study was a phase III, multicentre, randomised, double-masked, active-controlled, 52-week trial comparing the efficacy and safety of intravitreal aflibercept injection (IAI) with macular grid laser photocoagulation for treatment of macular oedema after BRVO. Participants 18 years old with BRVO or hemi-retinal vein occlusion (HRVO) causing oedema involving the centre of the macula were eligible for enrolment if the occlusion occurred within 12 months, and BCVA was between 73 and 24 Early Treatment Diabetic Retinopathy Study (ETDRS) letters (20/40 to $20 / 320$ Snellen equivalent). Eyes in the IAI group $(n=91)$ received $2 \mathrm{mg}$ IAI every four weeks from baseline to week 20. A sham laser treatment was also performed at baseline. After this, eyes received $2 \mathrm{mg} \mid \mathrm{Al}$ every eight weeks with rescue laser at week 36 if needed. Eyes in the laser group $(n=92)$ received macular laser photocoagulation at baseline and sham injections every four weeks from baseline to week 20. After this, eyes received three $2 \mathrm{mg} \mid \mathrm{Al}$ every four weeks; then 8-weekly with rescue laser at week 36 if needed. Eyes in both treatment groups were evaluated for rescue treatment from week 12 onward. The primary efficacy outcome measure was the proportion of eyes that gained 15 ETDRS letters in BCVA from baseline at week 24. The secondary efficacy outcome measures were a change from baseline in BCVA, CRT, and the National Eye Institute 25-item Visual Function Questionnaire (NEI VFQ-25) total scores. Additional prespecified endpoints were the time to first sustained gain of 15 letters, change from baseline in NEI VFQ-25 subscales (near activities, distance activities, and visual dependency), and proportion of participants with a change in retinal perfusion. Safety assessments included ocular and nonocular adverse events (AEs) and serious AEs (SAEs).This crossover design means results at six months are a true reflection of treatment efficacy. After this, eyes in the laser group were eligible to receive IAI, of which $80.7 \%$ did. In comparison, $10.6 \%$ of the IAI 
group received rescue laser at week 36 . Standard deviations for this study were obtained by email correspondence with the authors.

Included studies typically reported proportion of participants gaining 15 letters or more (RABAMES); or the mean change in visual acuity (BRIGHTER; Higashiyama 2013). Some reported both (Bandello 2018; BLOSSOM; COMRADE-B; Ramezani 2014; VIBRANT).

See the 'Characteristics of included studies' table for additional details.

\section{Excluded studies}

We excluded 26 studies. We excluded BRAVO 2010 due to the use of rescue laser treatment in both the sham and anti-VEGF arms; and Russo 2009 due to its quasi-RCT design. Three trials were dose-finding studies (Campochiaro 2008; Campochiaro 2010a; Wroblewski 2010); and one study had a follow-up period of less than six months (Moradian 2011). We excluded an additional seven studies as they examined combination therapy (Chiquet 2016; Donati 2012; Hanhart 2017; Kartasasmita 2016; Moon 2016; Tomomatsu 2016; Zhang 2014). We excluded four studies as they compared anti-VEGF treatment to other anti-VEGF therapy (CRAVE 2015; Klimes 2015; MARVEL; SHORE 2014). Four studies had a retrospective, non-randomised design (Chiquet 2015; Gu 2017; Guignier 2013; Leitritz 2013). Regnier 2015 is a review article. See the 'Characteristics of excluded studies' table and Table 2 for further details. From the search, we identified numerous interventional case series where anti-VEGF agents for $\mathrm{MO}$ secondary to BRVO were used. These did not meet the inclusion criteria for the systematic review, and primary outcomes for these are summarised in Table 1.

\section{Risk of bias in included studies}

Figure 2 highlights the 'Risk of bias' assessment for included studies in each domain.

\section{Figure 2. 'Risk of bias' summary: review authors' judgements about each risk of bias item for each included study.}

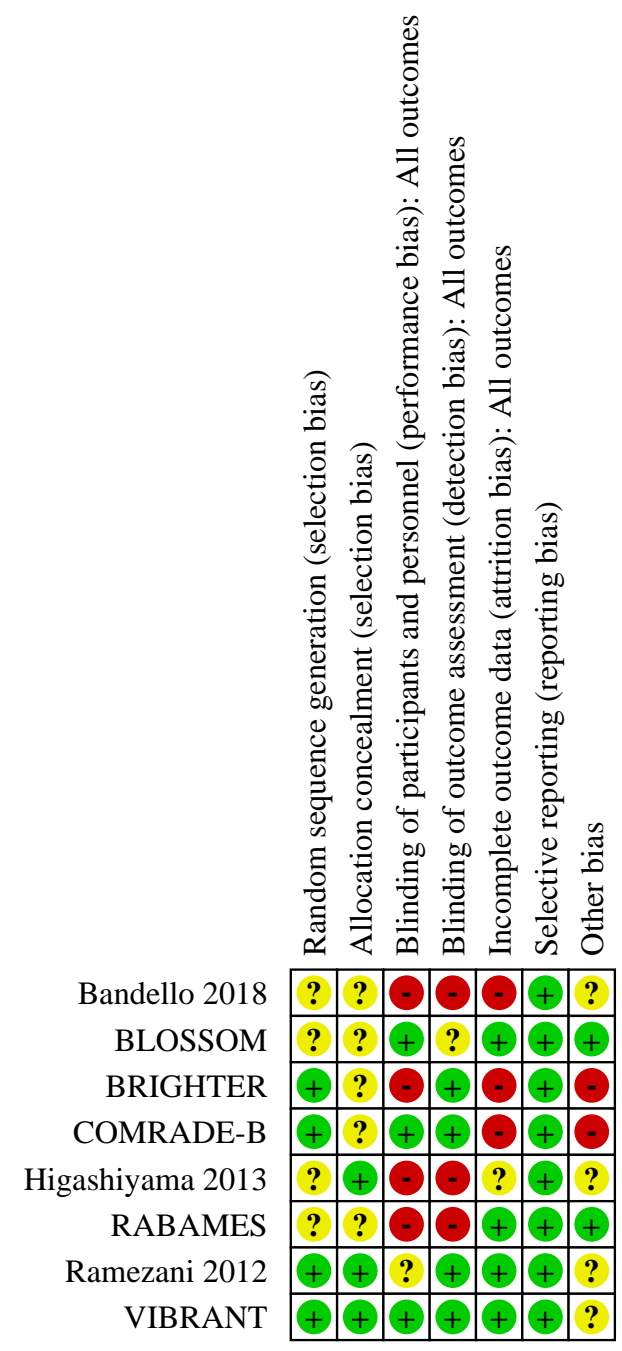


The included studies varied slightly in their eligibility criteria. Some only included treatment-naive participants, whilst others allowed previous treatment as long as it was given some time previously. Although no study gave a specific age range for inclusion, the mean participant age did vary between trials. Some studies were doublemasked, whilst others had poorer levels of masking.

Nevertheless, we judge the differences between studies to be small compared to the treatment effect and the results of this review can be interpreted with a high degree of certainty.

\section{Allocation}

Bandello 2018 showed unclear levels of selection bias with no information given about random sequence generation or allocation concealment.

BLOSSOM remains unpublished so the risk of allocation bias is unclear.

BRIGHTER had low risk of selection bias. The randomisation list was generated using a validated system that automates the random assignment of treatment arms to randomisation numbers in the specified ratio. Concealment of allocations was performed prior to assignment.

COMRADE-B also showed low risk of allocation bias and appropriate randomisation. At enrolment, participants were randomised 1:1 to receive either ranibizumab or dexamethasone intravitreal implant treatment. A randomisation list was produced using a validated system that randomly assigned the treatment arms to randomisation numbers in the specified ratio.

The study by Higashiyama and colleagues had unclear levels of selection bias. The doctor who designed and conducted this study (OS) was responsible for randomisation and random allocation performed by the others on the day that the participants received an intravitreal injection. The 'envelope' method was used for randomisation (Higashiyama 2013).

We judge RABAMES to be at low risk for selection bias. The randomisation list implemented blocked randomisation with one block of size 30 (10 eyes and participants per study arm) without any stratification. Randomization was performed by the coordinating study centre.

The study by Ramezani and colleagues is low risk for selection bias. Randomization was performed using a random block permutation method according to a computer-generated randomisation list. The block length varied randomly $(4,8)$. Random allocation sequence was performed by a biostatistician. He put the randomisation sequence in numbered, labelled, concealed envelopes. Whenever a new participant passed inclusion criteria a new envelope was opened and the group was revealed (Ramezani 2012).

VIBRANT was a large trial with low risk for selection bias. Eyes were randomised 1:1 into the IAI and laser groups according to a predetermined central randomisation scheme. Randomisation was provided by an interactive voice/web response system to the designated unmasked personnel.

\section{Blinding}

We deemed Bandello 2018 to be high risk for performance bias due to failure to mask investigators and participants.

BLOSSOM remains unpublished so the risk of performance and detection bias is unclear.

BRIGHTER had a high risk of performance and detection bias. There was no masking of investigators or participants (save for a visual acuity assessment investigator). Failing to mask the participant makes unmasking a high risk.

COMRADE-B was judged low risk for performance bias. A minimum of two investigators were involved, per study site, to fulfil the masking requirements. The injecting physician was unmasked and performed the study drug administrations as per the protocol; the physician was not involved in any other aspects of the study, however, and was not allowed to communicate the details of the treatment to anyone. Participants were masked and sham injections were given to the dexamethasone group after the baseline injection. The evaluating physician was masked to the treatment assigned so detection bias was minimal.

The risk of performance and detection bias was high in Higashiyama 2013. Treating doctors were not masked. Participants were masked although the nature of triamcinolone and bevacizumab injections are different symptomatically so this masking is likely compromised. Furthermore, outcome assessors were not masked.

RABAMES showed high risk of performance bias as there was no masking of investigators or participants save for OCT assessment. Nevertheless, OCT scans were evaluated by an independent retina specialist masked to the individual treatment.

Ramezani 2012 showed unclear risk of performance bias. The study group masked participants to their treatment; however, since triamcinolone might cause floaters they do not consider this study as a double-masked one. Detection bias was minimised at baseline and at each study visit thereafter: refraction and BCVA were determined, and OCT was performed by certified examiners masked both to the randomisation and to the findings of previous measurements.

VIBRANT had low risk of bias due to poor masking. A sham laser treatment was also performed at baseline. Eyes in the laser group received macular laser photocoagulation at baseline and sham injections every four weeks from baseline to week 20. Optical coherence tomography images were evaluated by an independent central reading centre.

\section{Incomplete outcome data}

Bandello 2018 was judged as high risk for attrition bias. Fortytwo participants did not complete the study in the Ozurdex arm compared to only 14 in the ranibizumab arm. The most common reason for Ozurdex failure of completion was adverse event (raised IOP).

In BLOSSOM, $94.0 \%$ of participants completed 12 months' followup (93.2\% in the ranibizumab arm and $95.7 \%$ in the sham arm). The intent-to-treat approach was used for efficacy analyses and included all participants as randomised. 
There was a high risk of attrition bias in BRIGHTER: $13 \%$ loss of participants from 'laser only' group at six months (half of these due to physicians' decision). The risk was also high in COMRADE-B, where the ranibizumab arm showed $91.3 \%$ followup at six months, higher than the $84.7 \%$ in the dexamethasone arm. The dexamethasone arm had six participant withdrawals due to inadequate response to treatment and six withdrawals due to adverse events (the nature of these is not clear).

In the Higashiyama 2013 study, three triamcinolone and four bevacizumab participants were lost to follow-up. These were not analysed in the 12-month results.

RABAMES was low risk for attrition bias as only one participant withdrew from the study. This was due to stroke and occurred in the combined ranibizumab and laser group. This was also the case for the study by Ramezani 2012, where only one participant was lost to follow-up at six months. This occurred in the bevacizumab group.

VIBRANT was low risk for attrition bias. All randomised eyes in both treatment groups were included in the full analysis set, except for two eyes in the laser group that did not have a post-baseline BCVA assessment.

\section{Selective reporting}

The following trials reported all pre-specified primary and secondary outcomes listed in their study protocol on ClinicalTrials.gov and we considered them at low risk for selective reporting: BLOSSOM, BRIGHTER (NCT01599650), COMRADEB (NCT01396057), Bandello 2018 (NCT01427751), RABAMES (NCT00562406), Ramezani 2012 (NCT00370266) and VIBRANT (NCT01521559).

The protocol for Higashiyama 2013 was not available and we are unable to exclude the possibility of selective reporting: we consider the study 'unclear' in this domain.

\section{Other potential sources of bias}

Some trials received pharmaceutical company funding.

Of the eight trials included, five received pharmaceutical company funding: BRIGHTER, COMRADE-B, Bandello 2018, RABAMES and VIBRANT. This support included study design, conducting the study, data collection, management and data interpretation to various degrees. There was also support for medical writing and editorial assistance.

\section{Effects of interventions}

See: Summary of findings 1 Anti-VEGF compared to sham for macular oedema secondary to branch retinal vein occlusion; Summary of findings 2 Anti-VEGF compared to laser for branch retinal vein occlusion (BRVO); Summary of findings 3 Anti-VEGF compared to steroid for branch retinal vein occlusion (BRVO)

\section{Anti-VEGF treatment versus sham}

\section{Improvement of 15 or more letters (primary outcome)}

People receiving anti-VEGF showed better outcome than those treated with sham injections at six months (RR $1.72,95 \% \mathrm{Cl} 1.19$ to $2.49 ; 1$ study, 283 participants; moderate-certainty evidence; Analysis 1.1). Unfortunately, this outcome was limited to only one trial and for only six months, as rescue treatment was available after this time (BLOSSOM).

\section{Mean change in best-corrected visual acuity (BCVA)}

People receiving anti-VEGF showed better improvement in mean visual acuity than those receiving sham at six months (MD 7.50 letters, $95 \% \mathrm{Cl} 5.29$ to $9.71 ; 1$ study, 282 participants; moderatecertainty evidence; Analysis 1.2).

\section{Loss of 15 or more letters}

People receiving anti-VEGF showed better outcome than those treated with sham injections at six months (RR 0.24). However, the $95 \% \mathrm{Cl}(0.05$ to 1.31$)$ included 1.00 (Analysis 1.3).

\section{Central retinal thickness $(C R T)$}

No data was available for 12 months but results at six months showed participants receiving anti-VEGF had a greater reduction in central retinal thickness than those receiving sham (MD -57.50 microns, $95 \% \mathrm{Cl}-108.63$ to $-6.37 ; 1$ study, 281 participants; moderate-certainty evidence; Analysis 1.4).

\section{Adverse events (AEs)}

The anti-VEGF and sham cohorts reported similar levels of ocular and systemic adverse events. Antiplatelet Trialists' Collaboration (APTC) arterial thromboembolic events were equally common in both groups. Endophthalmitis was rare.

\section{Quality of life}

The mean improvement in quality of life (QoL) at 12 months on the National Eye Institute Visual Functioning Questionnaire-25 (VFQ-25) (scored 0 to 100; higher score is better quality of life) was 7.60 higher (4.30 to 10.90) (1 study, 281 participants; moderatecertainty evidence; Analysis 1.8).

\section{Anti-VEGF treatment versus laser photocoagulation}

\section{Improvement of 15 or more letters (primary outcome)}

Eyes receiving anti-VEGF showed better outcome than the laser arm at six months (RR 2.09, 95\% Cl 1.44 to 3.05; 2 studies, 201 participants; $I^{2}=0 \%$; moderate-certainty evidence; Analysis 2.1). There were no results available for 12 months.

\section{Mean change in best-corrected visual acuity (BCVA)}

People receiving anti-VEGF showed greater gains than those receiving laser at six months (MD 9.63 letters, $95 \% \mathrm{Cl} 7.23$ to 12.03 ; 3 studies, 473 participants; $I^{2}=0 \%$; moderate-certainty evidence; Analysis 2.2; Figure 3). There were no results available for 12 months. 
Figure 3. Forest plot of comparison: 2 Anti-VEGF v laser, outcome: 2.2 Mean VA change at 6 months [letters].

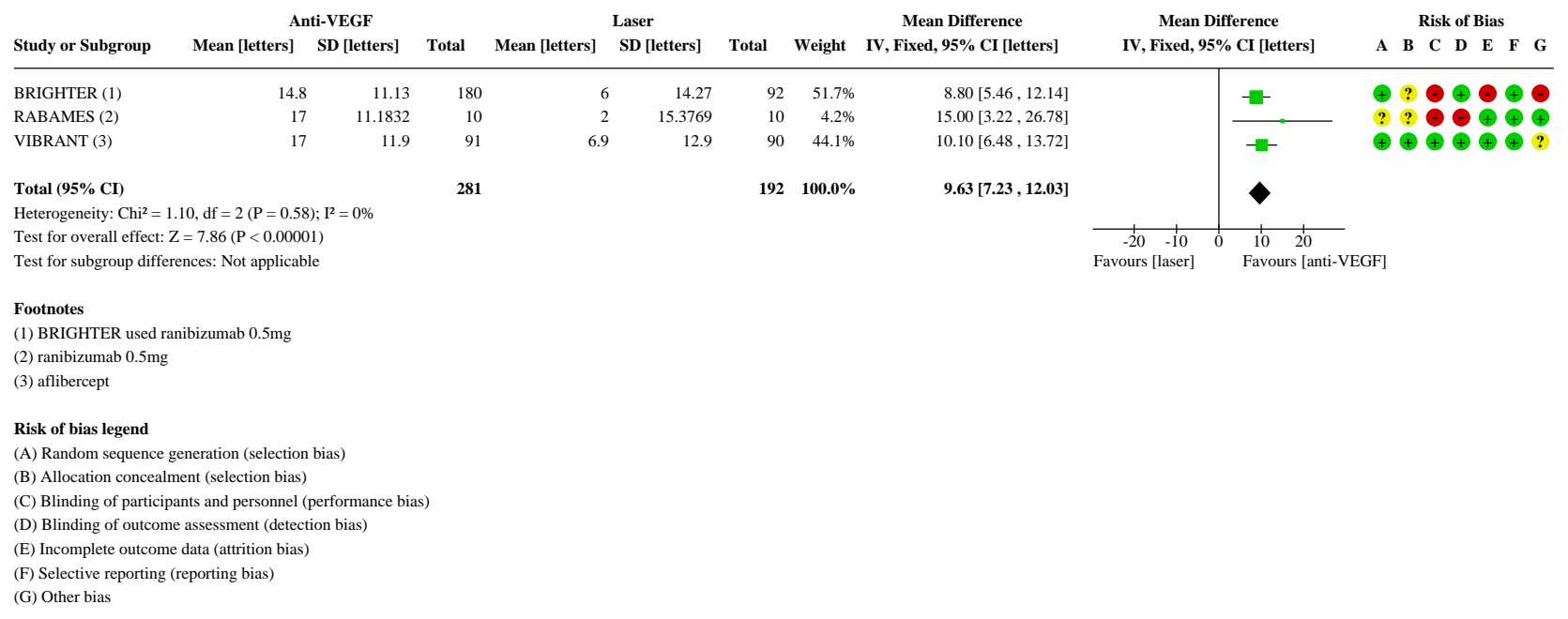

\section{Central retinal thickness (CRT)}

Mean change in CRT was greater in the anti-VEGF than the laser group at six months (MD -147.47 microns, $95 \% \mathrm{Cl}-200.19$ to -94.75 2 studies, 201 participants; $I^{2}=0 \%$; moderate-certainty evidence; Analysis 2.3) although no data was available for 12 months of treatment.

\section{Adverse events}

Systemic adverse events were well-matched between the antiVEGF and laser cohorts. There was no sign that thromboembolic events were more common in either group (Figure 4). There were no episodes of endophthalmitis after any intravitreal anti-VEGF injection.

Figure 4. Forest plot of comparison: 2 Anti-VEGF v laser, outcome: 2.5 APTC events.

\begin{tabular}{|c|c|c|c|c|c|c|c|c|}
\hline \multirow[b]{2}{*}{ Study or Subgroup } & \multicolumn{2}{|c|}{ Anti-VEGF } & \multicolumn{2}{|c|}{ Laser } & \multirow[b]{2}{*}{ Weight } & \multirow{2}{*}{$\begin{array}{c}\text { Risk Ratio } \\
\text { M-H, Fixed, 95\% CI }\end{array}$} & \multirow{2}{*}{$\begin{array}{c}\text { Risk Ratio } \\
\text { M-H, Fixed, 95\% CI }\end{array}$} & Risk of Bias \\
\hline & Events & Total & Events & Total & & & & $\begin{array}{lllllll}\mathbf{A} & \mathbf{B} & \mathbf{C} & \mathbf{D} & \mathbf{E} & \mathbf{F} & \mathbf{G}\end{array}$ \\
\hline BRIGHTER (1) & 0 & 183 & 0 & 92 & & Not estimable & & $+? \odot+\Theta+\epsilon$ \\
\hline RABAMES & 1 & 10 & 0 & 10 & $24.9 \%$ & $3.00[0.14,65.90]$ & $\longrightarrow$ & ? ? $\odot \odot \oplus+$ \\
\hline VIBRANT & 0 & 91 & 1 & 90 & $75.1 \%$ & $0.33[0.01,7.99]$ & & $\oplus+\oplus \oplus+\oplus$ ? \\
\hline Total $(95 \%$ CI $)$ & & 284 & & 192 & $100.0 \%$ & $0.99[0.15,6.78]$ & & \\
\hline Total events: & 1 & & 1 & & & & & \\
\hline \multicolumn{7}{|c|}{ Heterogeneity: $\mathrm{Chi}^{2}=0.95, \mathrm{df}=1(\mathrm{P}=0.33) ; \mathrm{I}^{2}=0 \%$} & 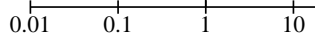 & 100 \\
\hline Test for overall effec & $=0.01(\mathrm{P}=$ & $=1.00)$ & & & & & More with [laser] & anti-VEGF] \\
\hline
\end{tabular}

Test for subgroup differences: Not applicable

Footnotes

(1) Data for first 6 months only as laser group was able to receive rescue anti-VEGF after this

Risk of bias legend

(A) Random sequence generation (selection bias)

(B) Allocation concealment (selection bias)

(C) Blinding of participants and personnel (performance bias)

(D) Blinding of outcome assessment (detection bias)

(E) Incomplete outcome data (attrition bias)

(F) Selective reporting (reporting bias)

(G) Other bias

\section{Quality of life}

This data was not reported.

\section{Anti-VEGF treatment versus steroid}

\section{Improvement of 15 or more letters (primary outcome)}

Participants receiving anti-VEGF showed better outcomes than steroid at six months (RR 1.67, 95\% Cl 1.33 to 2.10; 2 studies, 330 participants; $I^{2}=0 \%$; high-certainty evidence; Analysis 3.1; Figure 5); and 12 months (RR $1.76,95 \% \mathrm{Cl} 1.36$ to $2.28 ; 1$ study, 307 participants; high-certainty evidence; Analysis 3.2).

Anti-vascular endothelial growth factor for macular oedema secondary to branch retinal vein occlusion (Review) 
Figure 5. Forest plot of comparison: 3 Anti-VEGF v steroid, outcome: 3.1 Gain of 15 letters or more at 6 months.

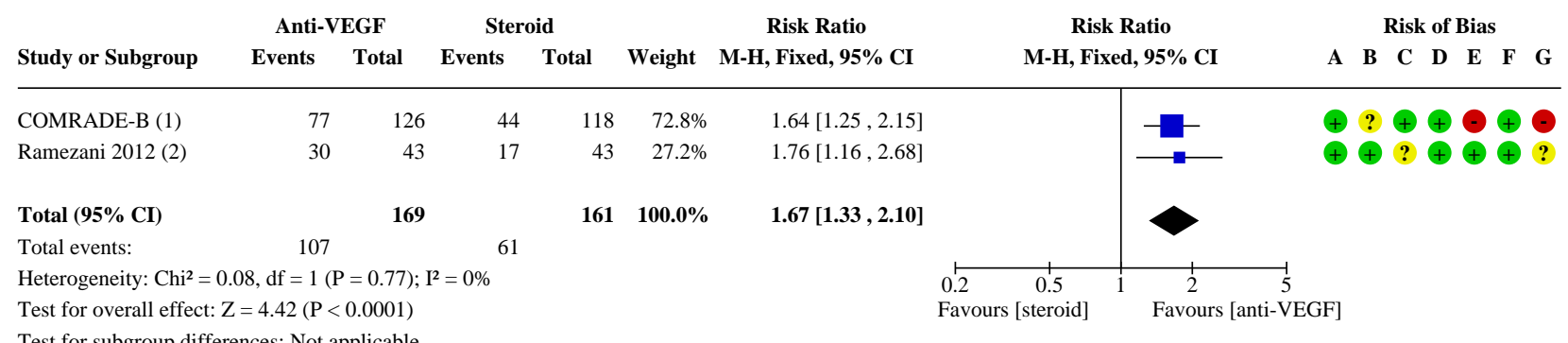

(1) ranibizumab $0.5 \mathrm{mg} v$ dexamethasone
(2) bevacizumab v triamcinolone

Risk of bias legend

(A) Random sequence generation (selection bias)

(B) Allocation concealment (selection bias)

(C) Blinding of participants and personnel (performance bias)

(D) Blinding of outcome assessment (detection bias)

(E) Incomplete outcome data (attrition bias)

(F) Selective reporting (reporting bias)

(G) Other bias

\section{Mean change in best-corrected visual acuity (BCVA)}

Eyes receiving anti-VEGF showed a great improvement in visual acuity than those in the steroid arm both at six months (MD 8.22 letters, $95 \% \mathrm{Cl} 5.69$ to 10.76 ; 2 studies, 330 participants; $I^{2}=0 \%$; high-certainty evidence; Analysis 3.3); and 12 months (MD 9.15 letters, $95 \% \mathrm{Cl} 6.32$ to $11.97 ; 2$ studies, 343 participants; $I^{2}=0 \%$; high-certainty evidence; Analysis 3.4).

\section{Central retinal thickness (CRT)}

Central macular thickness showed a greater reduction at 12 months in eyes receiving anti-VEGF than those receiving steroid (MD -26.92 microns, $95 \% \mathrm{Cl}-65.88$ to $12.04 ; 3$ studies, 343 participants; $I^{2}=0 \%$; moderate-certainty grade; Analysis 3.6).

\section{Adverse events}

Systemic adverse events were similar in the anti-VEGF and steroid cohorts. However, ocular adverse events were more common in the steroid cohort, who had greater rates of cataract formation (moderate-certainty evidence) and raised intraocular pressure (moderate-certainty evidence; Figure 6).

Figure 6. Forest plot of comparison: 3 Anti-VEGF v steroid, outcome: 3.9 Raised IOP.

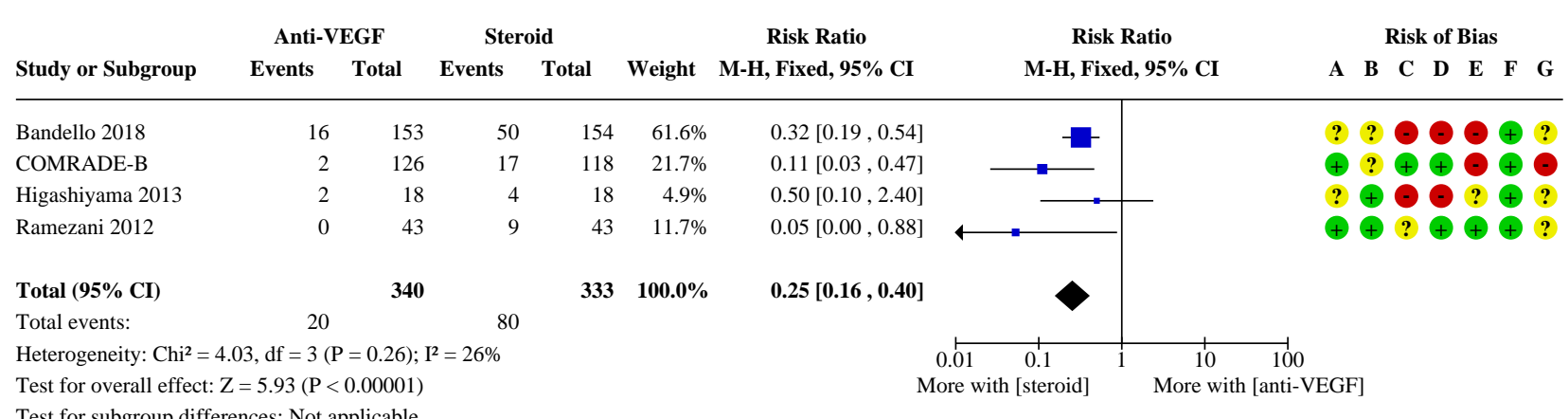

Test for subgroup differences: Not applicable

Risk of bias legend
(A) Random sequence generation (selection bias)
(B) Allocation concealment (selection bias)
(C) Blinding of participants and personnel (performance bias)
(D) Blinding of outcome assessment (detection bias)
(E) Incomplete outcome data (attrition bias)
(F) Selective reporting (reporting bias)
(G) Other bias 


\section{Quality of life}

Participants receiving anti-VEGF showed a greater improvement in quality of life at 12 months compared to those receiving steroid (MD 3.10, 95\% Cl 0.22 to 5.98; 1 study, 307 participants; moderatecertainty evidence).

\section{DISCUSSION}

\section{Summary of main results}

This systematic review and meta-analysis has revealed that in the treatment of macular oedema secondary to branch retinal vein occlusion, intravitreal anti-VEGF agents give the best outcomes and are as safe, or safer, than sham, laser photocoagulation or intravitreal steroid.

BLOSSOM study showed that anti-VEGF is more effective than sham in promoting visual gain and reducing visual loss over a 6-month follow-up. Anti-VEGF was also more effective at reducing central macular thickness.

Several studies compared anti-VEGF with laser, with follow-up of six months (RABAMES, BRIGHTER and VIBRANT). Together, these studies showed anti-VEGF is more effective than laser at improving visual outcome, reducing visual loss and promoting resolution of macular oedema.

Anti-VEGF is also more effective in achieving functional and anatomical outcomes than intravitreal steroid, both triamcinolone and dexamethasone implant (COMRADE-B, Ramezani 2012, Bandello 2018, and Higashiyama 2013). Anti-VEGF has a better adverse event profile, and improves quality of life more than steroid.

\section{Overall completeness and applicability of evidence}

\section{Intravitreal anti-VEGF treatment and sham}

This comparison included only one study, and this was limited to six months as rescue treatment with anti-VEGF was possible after this for the sham arm (BLOSSOM). The BRAVO 2010 study had to be excluded as rescue laser was available to both the sham and antiVEGF arms of the study. Although BLOSSOM remains unpublished, the data provided by this trial give good high-certainty evidence for the benefit of anti-VEGF over sham.

\section{Intravitreal anti-VEGF treatment and grid laser photocoagulation (GLP)}

Overall, this involved a total of 473 participants and two anti-VEGF agents were represented: ranibizumab (RABAMES and BRIGHTER), and aflibercept (VIBRANT).

The studies generally included participants with a wide range of baseline visual acuity, typically 20/40 and 20/400. RABAMES included only perfused (non-ischaemic) BRVO whereas this was not a specified criterion in BRIGHTER or VIBRANT. Eyes with ischaemic BRVO tend to have poorer baseline acuity, and there is thus insufficient study data to predict the efficacy of anti-VEGF or laser treatment in these eyes.

Furthermore, VIBRANT included hemi-retinal vein occlusion (HRVO) as a form of BRVO whereas it is not clear whether the other studies did this also. As HRVO is considered by some authorities as a subtype of CRVO rather than BRVO, it is unclear whether the inclusion of these eyes makes a meaningful difference to the results and conclusions.

RABAMES included treatment-naive participants only although the other studies permitted inclusion of participants who had previously been treated. Participants seen in clinic outside a clinical trial setting are more likely to have had previous treatment, as well as ocular comorbidities such as diabetic retinopathy. As more such participants were excluded from the clinical trials, the effect of ocular comorbidity cannot be determined with any certainty.

\section{Intravitreal anti-VEGF treatment and intravitreal steroid}

Four RCTs contributed data to this comparison, two comparing anti-VEGF with intravitreal triamcinolone (Higashiyama 2013 and Ramezani 2012) and two comparing anti-VEGF with intravitreal dexamethasone implant (COMRADE-B and Bandello 2018). Both bevacizumab (Higashiyama 2013 and Ramezani 2012) and ranibizumab (COMRADE-B and Bandello 2018) were included.

Higashiyama 2013 included treatment-naive eyes of less than 12-months disease duration, although there is no mention of ischaemic status. Ramezani 2012 also included treatment-naive eyes only, but limited this to disease duration of 12 weeks or less at baseline. COMRADE-B permitted previously treated eyes but stipulated a treatment-free period of three months for antiVEGF and six months for prior intravitreal steroids. Bandello 2018 included treatment-naive eyes only with symptom duration of three months or less. The study also excluded eyes with 'severe macular ischaemia'.

\section{Quality of the evidence}

\section{Intravitreal anti-VEGF treatment and sham}

We found one RCT with good methodological quality for this comparison (BLOSSOM). This, however, remains unpublished so we obtained data from ClinicalTrials.gov.

\section{Intravitreal anti-VEGF treatment and grid laser photocoagulation (GLP)}

A total of three studies contributed data to this comparison (RABAMES, BRIGHTER and VIBRANT). VIBRANT and BRIGHTER were particularly large studies with good study design.

RABAMES has low risk of selection bias but high risk of performance and detection bias due to a lack of masking of participants or assessors. Nevertheless, the two largest RCTs (BRIGHTER and VIBRANT) showed good study design with a low risk of bias.

\section{Intravitreal anti-VEGF treatment and intravitreal steroid}

Four RCTs were included in this analysis. These studies showed a high risk of bias. Higashiyama 2013 failed to mask participants and outcome assessors, meaning a high risk of performance and detection bias. Ramezani 2012 did mask outcome assessors, but there was insufficient information in the article to determine whether allocation concealment was performed to a high enough level to avoid selection bias. Although COMRADE-B was well designed to avoid bias, limiting dexamethasone use to baseline only with outcomes reported at six months meant a waning of the treatment effect of this drug. Bandello 2018 failed to mask 
investigators and participants, so has high risk of performance and detection bias.

\section{Heterogeneity}

Subgroup analysis comparing the effect of the three anti-VEGF agents (bevacizumab, ranibizumab and aflibercept) showed no difference in efficacy.

Overall, heterogeneity was low across studies, with low $\mathrm{Chi}^{2}$, high $\mathrm{P}$ values and low $I^{2}$ values. There was, however, one exception to this.

In Analysis 3.5, heterogeneity was observed between COMRADE$B$ and Ramezani 2012 for mean CRT at six months. Participants in the steroid arm of COMRADE-B did poorly compared to those in the steroid arm of Ramezani 2012. In Ramezani 2012, eyes in the steroid arm received two injections of intravitreal steroid spaced two months apart, meaning the treatment effect was more sustained, whilst those in COMRADE-B only received a single dose of steroid at baseline. This might explain the observed heterogeneity.

\section{Potential biases in the review process}

The studies included in this review typically only provided data for six months of treatment, save Higashiyama 2013 and Bandello 2018, which had 12 months of follow-up. Typically, the study designs permitted rescue treatment after six months, hence necessitating exclusion after this. Short follow-up of six months can introduce bias, particularly in investigation of adverse events, such as cataract formation in the use of intravitreal steroids.

Included studies showed some clinical heterogeneity as they were conducted in diverse ethnicities and also showed differences in inclusion criteria, such as the inclusion or exclusion of ischaemic BRVO. We judged the effect of this to be small compared to the treatment effects observed.

Further heterogeneity arose from the anti-VEGF used within the studies, as bevacizumab, ranibizumab and aflibercept were all used. We judged the effect of this also to be small due to the similar efficacy of all three agents demonstrated in the results.

\section{Statistical heterogeneity between studies was low.}

We found intra-study selective outcome reporting to be minimal for all but two of the included studies. This was demonstrated by comparing the published results with the study protocol. The protocol for Higashiyama 2013 was not available on ClinicalTrials.gov and we are unable to exclude the possibility of selective reporting.

Publication bias was avoided by using trial registries to look for studies to include. One study was not published but we obtained data from the trial registry (BLOSSOM). We also contacted the authors of this study to obtain further study information, such as that needed to assess risk of bias.

Studies comparing anti-VEGF with steroid showed poor masking of study participants and outcome assessors. This is most likely due to the nature of the respective injection, which is colourless liquid for anti-VEGF and crystals/implant for steroid. This exposes this group of studies to performance and detection bias.

\section{Agreements and disagreements with other studies or reviews}

We found three systematic reviews using our search strategy. The first preceded the widespread use of intravitreal anti-VEGF for BRVO and does not report recent studies examining the efficacy of this treatment (McIntosh 2007). The second, Regnier 2015, evaluated treatments for BRVO to 2015, finding eight RCTs with a total of 1743 adult participants. As with our systematic review, anti-VEGF agents were found to be more effective than steroids or laser in improving visual acuity at six and 12 months. Anti-VEGF agents were also safer than intravitreal steroids, that were associated with intraocular pressure rise. Qian 2017, the third systematic review that we found, also performed a systematic review but included CRVO as well as BRVO studies to 2017. In BRVO, this review found anti-VEGF agents to be more effective than steroids or laser in improving visual acuity at three, six and 12 months, with lower IOP compared to steroids.

\section{AUTHORS' CONCLUSIONS}

\section{Implications for practice}

Based on the findings of this systematic review of multiple randomised controlled trials of cystoid macular oedema in branch retinal vein occlusion, anti-VEGF agents provide the most effective treatment in terms of functional (visual acuity) and anatomical (central macular thickness) outcomes when compared with sham, macular laser or intravitreal steroids. They also proved a safer treatment than intravitreal steroids, which led to an increase in intraocular pressure and cataract formation.

The follow-up of the RCTs included was variable. Studies comparing anti-VEGF with sham or laser were short, with up to six months' follow-up before rescue treatment was permitted. Trials comparing anti-VEGF with intravitreal steroid were six to 12 months in duration. This makes long-term comparison of treatment effect difficult.

The economic implications of anti-VEGF treatment are significant. The drugs licensed for intraocular use (ranibizumab and aflibercept) are expensive. Bevacizumab is much cheaper although not licensed for intraocular use. All drugs require frequent injection, typically monthly for the first three doses. This requires an expanded healthcare delivery system composed of treating doctors, nurses as well as administrative staff. Longer-acting treatments such as laser or steroid injection do not require a large expansion in the capacity of the healthcare system. The cost of delivering anti-VEGF treatment is passed on the taxpayer in many developed nations, such as in Europe. Nevertheless, poorer people in poor countries face a struggle to afford frequent anti-VEGF treatment.

\section{Implications for research}

Future research should focus on comparing the various anti-VEGF agents (bevacizumab, ranibizumab, aflibercept) against each other to determine which, if any, is most effective in the treatment of BRVO. Better description of patient subgroups (e.g. ischaemic versus non-ischaemic; type of vein occlusion - BRVO/HRVO) and transparent reporting of subgroup outcomes will be important. Re-treatment decision criteria should be standardised and easy to apply, and more consideration should be given to the time from onset of BRVO and individuals who have previously received other treatments. Trial investigators should report the proportion 
of patients gaining or losing 15 or more ETDRS letters as well as mean changes in VA.

\section{ACKNOWLEDGEMENTS}

Cochrane Eyes and Vision (CEV) created and executed the electronic searches. We thank David Charteris and Robin Hamilton for their contributions to a first publication of this review (Mitry 2011). We would like to acknowledge and thank Anupa Shah and Jennifer Evans for their help and assistance throughout the review process. We thank Tasanee Braithwaite, Gianni Virgili and Kristina Lindsley for their comments on the review. 


\section{R E F E R E N C E S}

\section{References to studies included in this review}

\section{Bandello 2018 \{published and unpublished data\}}

Bandello F, Augustin A, Tufail A, Leaback R. A 12-month, multicenter, parallel group comparison of dexamethasone intravitreal implant versus ranibizumab in branch retinal vein occlusion. European Journal of Ophthalmology 2018;28(6):697705.

EU-CTR 2010-023900-29. A 12-month, multicentre, randomised, parallel group study to compare the efficacy and safety of OZURDEX ${ }^{\circledast}$ versus Lucentis ${ }^{\circledR}$ in patients with branch retinal vein occlusion. www.clinicaltrialsregister.eu/ctr-search/ trial/2010-023900-29/results (first received 28 August 2011).

NCT01427751. Safety and efficacy study of Ozurdex ${ }^{\circledR}$ compared to Lucentis ${ }^{\circledR}$ in patients with branch retinal vein occlusion. clinicaltrials.gov/ct2/show/NCT01427751 (first received 2 September 2011).

\section{BLOSSOM \{unpublished data only\}}

NCT01976338. Ranibizumab intravitreal injections versus sham control in patients with branch retinal vein occlusion (BRVO) (Blossom). ClinicalTrials.gov/show/NCT01976338 (first received 5 November 2013).

Wei W. To assess the efficacy and safety of individualized intravitreal ranibizumab $0.5 \mathrm{mg}$ in Asian (primarily Chinese) patients with visual impairment due to macular edema secondary to branch retinal vein occlusion (BRVO). In: Annual Meeting of the Association for Research in Vision and Ophthalmology. 2017.

\section{BRIGHTER \{published data only\}}

Tadayoni R, Waldstein SM, Boscia F, Gerding H, Gekkieva M, Barnes $E$, et al. Sustained benefits of ranibizumab with or without laser in branch retinal vein occlusion: 24-month results of the BRIGHTER study. Ophthalmology 2017;124(12):1778-87.

Tadayoni R, Waldstein SM, Boscia F, Gerding H, Pearce I, Priglinger $\mathrm{S}$, et al. Individualized stabilization criteriadriven ranibizumab versus laser in branch retinal vein occlusion: six-month results of BRIGHTER. Ophthalmology 2016;123(6):1332-44.

\section{COMRADE-B \{published data only\}}

Hattenbach LO, Feltgen N, Bertelmann T, SchmitzValckenberg S, Berk H, Eter N, et al. Head-to-head comparison of ranibizumab PRN versus single-dose dexamethasone for branch retinal vein occlusion (COMRADE-B). Acta Ophthalmologica 2018;96(1):e10-8.

\section{Higashiyama 2013 \{published data only\}}

Higashiyama T, Sawada O, Kakinoki M, Sawada T, Kawamura H, Ohji M. Prospective comparisons of intravitreal injections of triamcinolone acetonide and bevacizumab for macular oedema due to branch retinal vein occlusion. Acta Ophthalmologica 2013;91(4):318-24.
RABAMES \{published data only\}

Pielen A, Mirshahi A, Feltgen N, Lorenz K, Korb C, Junker B, et al. Ranibizumab for branch retinal vein occlusion associated macular edema study (RABAMES): six-month results of a prospective randomized clinical trial. Acta Ophthalmologica 2015;93(1):e29-37.

\section{Ramezani 2012 \{published data only\}}

Ramezani A, Esfandiari H, Entezari M, Moradian S, Soheilian M, Dehsarvi B, et al. Three intravitreal bevacizumab versus two intravitreal triamcinolone injections in recent-onset branch retinal vein occlusion. Graefe's Archive for Clinical and Experimental Ophthalmology 2012;250(8):1149-60.

VIBRANT \{published data only\}

Campochiaro PA, Clark WL, Boyer DS, Heier JS, Brown DM, Vitti R, et al. Intravitreal aflibercept for macular edema following branch retinal vein occlusion: the 24-week results of the VIBRANT study. Ophthalmology 2015;122(3):538-44.

Clark WL, Boyer DS, Heier JS, Brown DM, Haller JA, Vitti R, et al. Intravitreal aflibercept for macular edema following branch retinal vein occlusion: 52-week results of the VIBRANT study. Ophthalmology 2016;123(2):330-6.

\section{References to studies excluded from this review \\ BRAVO 2010 \{published data only\}}

Brown DM, Campochiaro PA, Bhisitkul RB, Ho AC, Gray S, Saroj N, et al. Sustained benefits from ranibizumab for macular edema following branch retinal vein occlusion: 12-month outcomes of a phase III study. Ophthalmology 2011;118(8):1594-602.

Campochiaro PA, Heier JS, Feiner L, Gray S, Saroj N, Rundle AC, et al. Ranibizumab for macular edema following branch retinal vein occlusion: six-month primary end point results of a phase III study. Ophthalmology 2010;117(6):1102-12.

Campochiaro 2008 \{published data only\}

Campochiaro PA, Hafiz G, Shah SM, Nguyen QD, Ying H, Do DV, et al. Ranibizumab for macular edema due to retinal vein occlusions: implication of VEGF as a critical stimulator. Molecular Therapy 2008;16(4):791-9.

\section{Campochiaro 2010a \{published data only\}}

Campochiaro PA, Hafiz G, Channa R, Shah SM, Nguyen QD, Ying $\mathrm{H}$, et al. Antagonism of vascular endothelial growth factor for macular edema caused by retinal vein occlusions: two-year outcomes. Ophthalmology 2010;117(12):2387-94.

\section{Chiquet 2015 \{published data only\}}

Chiquet C, Dupuy C, Bron AM, Aptel F, Straub M, Isaico R, et al. Intravitreal dexamethasone implant versus anti-VEGF injection for treatment-naive patients with retinal vein occlusion and macular edema: a 12-month follow-up study. Graefe's Archive for Clinical and Experimental Ophthalmology 2015;253(12):2095-102. 
Chiquet 2016 \{published data only\}

Chiquet C, Bron AM, Straub M, Dupuy C, Isaico R, Aptel F, et al. Retinal vein occlusions: therapeutic switch in macular oedema treatment with a 12-month follow-up. Ophthalmic Research 2016;55(3):152-8.

\section{COMRADE Extension 2018 \{published data only\}}

Feltgen N, Hattenbach LO, Bertelmann T, Callizo J, Rehak M, Wolf $\mathrm{A}$, et al. Comparison of ranibizumab versus dexamethasone for macular oedema following retinal vein occlusion: 1-year results of the COMRADE extension study. Acta Ophthalmologica 2018;96(8):e933-e941.

\section{CRAVE 2015 \{published data only\}}

Rajagopal R, Shah GK, Blinder KJ, Altaweel M, Eliott D, Wee R, et al. Bevacizumab versus ranibizumab in the treatment of macular edema due to retinal vein occlusion: 6-month results of the CRAVE study. Ophthalmic Surgery, Lasers \& Imaging Retina 2015;46(8):844-50.

\section{Donati 2012 \{published data only\}}

Donati S, Barosi P, Bianchi M, Al Oum M, Azzolini C. Combined intravitreal bevacizumab and grid laser photocoagulation for macular edema secondary to branch retinal vein occlusion. European Journal of Ophthalmology 2012;22(4):607-14.

\section{Gu 2017 \{published data only\}}

Gu X, Yu X, Song S, Dai H. Intravitreal dexamethasone implant versus intravitreal ranibizumab for the treatment of macular edema secondary to retinal vein occlusion in a Chinese population. Ophthalmic Research 2017;58(1):8-14.

\section{Guignier 2013 \{published data only\}}

Guignier B, Subilia-Guignier A, Fournier I, Ballonzoli L, SpeegSchatz C, Gaucher D. Prospective pilot study: efficacy of intravitreal dexamethasone and bevacizumab injections in the treatment of macular oedema associated with branch retinal vein occlusion. Ophthalmologica 2013;230(1):43-9.

\section{Hanhart 2017 \{published data only\}}

Hanhart J, Rozenman Y. Comparison of intravitreal ranibizumab, aflibercept, and dexamethasone implant after bevacizumab failure in macular edema secondary to retinal vascular occlusions. Ophthalmologica 2017;238(1-2):110-8.

\section{Kartasasmita 2016 \{published data only\}}

Kartasasmita AS, Takarai S, Switania A, Enus S. Efficacy of single bevacizumab injection as adjuvant therapy to laser photocoagulation in macular edema secondary to branch retinal vein occlusion. Clinical Ophthalmology 2016;10:2135-40.

\section{Klimes 2015 \{published data only\}}

Klimes J, Regnier SA, Mahon R, Budek T, Dostal F, Skalicky D, Depta J. Cost effectiveness analysis of ranibizumab compared to aflibercept and laser intervention In treatment of diabetic macular edema (DME) In the Czech Republic. Value in Health 2015;18:A 419.

\section{Leitritz 2013 \{published data only\}}

Leitritz MA, Gelisken F, Ziemssen F, Szurman P, BartzSchmidt KU, Jaissle GB. Grid laser photocoagulation for macular oedema due to branch retinal vein occlusion in the age of bevacizumab? Results of a prospective study with crossover design. British Journal of Ophthalmology 2013;97(2):215-9.

\section{Liu 2014 \{published data only\}}

Liu B, Yang Y, Liu X, Li W, Mo Z. Clinical therapeutic effects of intravitreal Ranibizumab injection combined laser photocoagulation for macular edema in BRVO. Guoji Yanke Zazhi 2014;14(11):2006-8.

\section{MARVEL \{published data only\}}

Narayanan R, Panchal B, Das T, Chhablani J, Jalali S, Ali MH, et al. A randomised, double-masked, controlled study of the efficacy and safety of intravitreal bevacizumab versus ranibizumab in the treatment of macular oedema due to branch retinal vein occlusion: MARVEL Report No. 1. British Journal of Ophthalmology 2015;99(7):954-9.

\section{Moon 2016 \{published data only\}}

Moon J, Kim M, Sagong M. Combination therapy of intravitreal bevacizumab with single simultaneous posterior subtenon triamcinolone acetonide for macular edema due to branch retinal vein occlusion. Eye 2016;30(8):1084-90.

\section{Moradian 2011 \{published data only\}}

Moradian S, Faghihi H, Sadeghi B, Piri N, Ahmadieh H, Soheilian M, et al. Intravitreal bevacizumab vs. sham treatment in acute branch retinal vein occlusion with macular edema: results at 3 months (Report 1). Graefe's Archive for Clinical and Experimental Ophthalmology 2011;249(2):193-200.

\section{Ramezani 2014 \{published data only\}}

Ramezani A, Esfandiari H, Entezari M, Moradian S, Soheilian M, Dehsarvi $B$, et al. Three intravitreal bevacizumab versus two intravitreal triamcinolone injections in recent onset central retinal vein occlusion. Acta Ophthalmologica 2014;92(7):e530-9.

\section{Regnier 2015 \{published data only\}}

Regnier SA, Larsen M, Bezlyak V, Allen F. Comparative efficacy and safety of approved treatments for macular oedema secondary to branch retinal vein occlusion: a network metaanalysis. BMJ Open 2015;5(6):e007527.

\section{Russo 2009 \{published data only\}}

Russo V, Barone A, Conte E, Prascina F, Stella A, Noci ND. Bevacizumab compared with macular laser grid photocoagulation for cystoid macular edema in branch retinal vein occlusion. Retina 2009;29(4):511-5.

SHORE 2014 \{published data only\}

Campochiaro PA, Wykoff CC, Singer M, Johnson R, Marcus D, Yau $\mathrm{L}$, et al. Monthly versus as-needed ranibizumab injections in patients with retinal vein occlusion: the SHORE study. Ophthalmology 2014;121(12):2432-42.

\section{Tan 2014 \{published data only\}}

Tan MH, McAllister IL, Gillies ME, Verma N, Banerjee, Smithies LA, et al. Randomized controlled trial of intravitreal ranibizumab versus standard grid laser for macular edema following branch retinal vein occlusion. American Journal of Ophthalmology 2014;157(1):237-47. 
Tomomatsu 2016 \{published data only\}

Tomomatsu Y, Tomomatsu T, Takamura Y, Gozawa M, Arimura S, Takihara Y, et al. Comparative study of combined bevacizumab/ targeted photocoagulation vs bevacizumab alone for macular oedema in ischaemic branch retinal vein occlusions. Acta Ophthalmologica 2016;94(3):e225-30.

\section{Wroblewski 2010 \{published data only\}}

Wroblewski JJ, Wells JA 3rd, Gonzales CR. Pegaptanib sodium for macular edema secondary to branch retinal vein occlusion. American Journal of Ophthalmology 2010;149(1):147-54.

\section{Zhang 2014 \{published data only\}}

Zhang XY, Li YB, Zhou LW, Wang XB, Luo XD. Observation on intravitreal injection of ranibizumab combined with laser photocoagulation for the treatment of macular edema in BRVO. International Eye Science 2014;14:747-9.

\section{References to ongoing studies}

\section{NCT01189526 \{unpublished data only\}}

NCT01189526. Comparison of intravitreal ranibizumab and macular laser photocoagulation for ME following branch retinal vein occlusion (BRVO). clinicaltrials.gov/ct2/show/NCT01189526 (first received 26 August 2010).

\section{NCT01795209 \{unpublished data only\}}

NCT01795209. Ranibizumab for macular edema secondary to branch retinal vein occlusion in patients with fair vision (RVOFV). clinicaltrials.gov/ct2/show/NCT01795209 (first received 20 February 2013).

\section{NCT03108352 \{unpublished data only\}}

NCT03108352. Conbercept ophthalmic injection for patients with macular edema caused by branch retinal vein occlusion. clinicaltrials.gov/ct2/show/NCT03108352 (first received 11 April 2017).

\section{Additional references}

\section{Abegg 2008}

Abegg M, Tappeiner C, Wolf-Schnurrbusch U, Barthelmes D, Wolf S, Fleischhauer J. Treatment of branch retinal vein occlusion induced macular edema with bevacizumab. BMC Ophthalmology 2008;8:18. [DOI: 10.1186/1471-2415-8-18]

\section{Ahmadi 2009}

Ahmadi AA, Chuo JY, Banashkevich A, Ma PE, Maberley DA. The effects of intravitreal bevacizumab on patients with macular edema secondary to branch retinal vein occlusion. Canadian Journal of Ophthalmology 2009;44(2):154-9.

\section{Aiello 1995a}

Aiello LP, Pierce EA, Foley ED, Takagi $\mathrm{H}$, Chen H, Riddle L, et al. Suppression of retinal neovascularization in vivo by inhibition of vascular endothelial growth factor (VEGF) using soluble VEGF-receptor chimeric proteins. Proceedings of the National Academy of Sciences of the United States of America 1995;92(23):10457-61.

\section{Aiello 1995b}

Aiello LP, Northrup JM, Keyt BA, Takagi H, Iwamoto MA. Hypoxic regulation of vascular endothelial growth factor in retinal cells. Archives of Ophthalmology 1995;113(12):1538-44.

\section{Awdeh 2010}

Awdeh RM, Elsing SH, Deramo VA, Stinnett S, Lee PP, Fekrat S. Vision-related quality of life in persons with unilateral branch retinal vein occlusion using the 25 -item National Eye Institute Visual Function Questionnaire. British Journal of Ophthalmology 2010;94(3):319-23.

\section{Boyd 2002}

Boyd SR, Zachary I, Chakravarthy U, Allen GJ, Wisdom GB, Cree IA, et al. Correlation of increased vascular endothelial growth factor with neovascularization and permeability in ischemic central vein occlusion. Archives of Ophthalmology 2002;120(12):1644-50.

\section{BVOS Group 1984}

The Branch Vein Occlusion Study Group. Argon laser photocoagulation for macular edema in branch vein occlusion. American Journal of Ophthalmology 1984;98(3):271-82.

\section{Byeon 2007}

Byeon SH, Kwon YA, Oh HS, Kim M, Kwon OW. Short-term results of intravitreal bevacizumab for macular edema with retinal vein obstruction and diabetic macular edema. Journal of Ocular Pharmacology and Therapeutics 2007;23(4):387-94.

\section{Byun 2010}

Byun YJ, Roh MI, Lee SC, Koh HJ. Intravitreal triamcinolone acetonide versus bevacizumab therapy for macular edema associated with branch retinal vein occlusion. Graefe's Archive for Clinical and Experimental Ophthalmology 2010;248(7):963-71.

\section{Campochiaro 2010b}

Campochiaro PA, Heier JS, Feiner L, Gray S, Saroj N, Rundle AC et al. Ranibizumab for macular edema following branch retinal vein occlusion: six-month primary end point results of a phase III study. Ophthalmology 2010;117(6):1102-12.

\section{Cekic 2010}

Cekic O, Cakir M, Yazici AT, Alagoz N, Bozkurt E, Faruk Yilmaz O. A comparison of three different intravitreal treatment modalities of macular edema due to branch retinal vein occlusion. Current Eye Research 2010;35(10):925-9.

\section{Chen 2010}

Chen $\mathrm{CH}$, Chen YH, Wu PC, Chen YJ, Lee JJ, Liu YC, et al. Treatment of branch retinal vein occlusion induced macular edema in treatment-naive cases with a single intravitreal triamcinolone or bevacizumab injection. Chang Gung Medical Journal 2010;33(4):424-35.

\section{Cheng 2009}

Cheng KC, Wu WC, Chen KJ. Intravitreal triamcinolone acetonide vs bevacizumab for treatment of macular oedema secondary to branch retinal vein occlusion. Eye 2009;23(11):2023-33. 


\section{Chung 2008}

Chung EJ, Hong YT, Lee SC, Kwon OW, Koh HJ. Prognostic factors for visual outcome after intravitreal bevacizumab for macular edema due to branch retinal vein occlusion. Graefe's Archive for Clinical and Experimental Ophthalmology 2008;246(9):1241-7.

\section{Deeks 2017}

Deeks JJ, Higgins JP, Altman DG, editor(s) on behalf of the Cochrane Statistical Methods Group. Chapter 9: Analysing data and undertaking meta-analyses. In: Higgins JPT, Churchill R, Chandler J, Cumpston MS (editors), Cochrane Handbook for Systematic Reviews of Interventions version 5.2.0 (updated June 2017), Cochrane, 2017. Available from www.training.cochrane.org/handbook.

\section{Dodson 1982}

Dodson PM, Galton DJ, Hamilton AM, Blach RK. Retinal vein occlusion and the prevalence of lipoprotein abnormalities. British Journal of Ophthalmology 1982;66(3):161-4.

\section{Dodson 1992}

Dodson PM, Kritzinger EE, Clough CG. Diabetes mellitus and retinal vein occlusion in patients of Asian, West Indian and white European origin. Eye 1992;6(1):66-8.

\section{EDCCS Group 1993}

Anonymous. Risk factors for branch retinal vein occlusion. The Eye Disease Case-Control Study Group. American Journal of Ophthalmology 1993;116(3):286-96.

\section{Ehlers 2011}

Ehlers JP, Fekrat S. Retinal vein occlusion: beyond the acute event. Survey of Ophthalmology 2011;56(4):281-99.

\section{Ferrara 2006}

Ferrara N, Damico L, Shams N, Lowman H, Kim R. Development of ranibizumab, an anti-vascular endothelial growth factor antigen binding fragment, as therapy for neovascular agerelated macular degeneration. Retina 2006;26(8):859-70.

\section{Figueroa 2010}

Figueroa MS, Contreras I, Noval S, Arruabarrena C. Results of bevacizumab as the primary treatment for retinal vein occlusions. British Journal of Ophthalmology 2010;94(8):1052-6.

\section{Frangieh 1982}

Frangieh GT, Green WR, Barraquer-Somers E, Finkelstein D. Histopathologic study of nine branch retinal vein occlusions. Archives of Ophthalmology 1982;100(7):1132-40.

\section{Funk 2009}

Funk M, Kriechbaum K, Prager F, Benesch T, Georgopoulos M, Zlabinger GJ, et al. Intraocular concentrations of growth factors and cytokines in retinal vein occlusion and the effect of therapy with bevacizumab. Investigative Ophthalmology and Visual Science 2009;50(3):1025-32.

\section{Garnock-Jones 2011}

Garnock-Jones KP. Ranibizumab: in macular oedema following retinal vein occlusion. Drugs 2011;71(4):455-63.

\section{Glacet-Bernard 1996}

Glacet-Bernard A, Coscas G, Chabanel A, Zourdani A, Lelong F, Samama MM. Prognostic factors for retinal vein occlusion: prospective study of 175 cases. Ophthalmology 1996;103(4):551-60.

\section{Glanville 2006}

Glanville JM, Lefebvre C, Miles JN, Camosso-Stefinovic J. How to identify randomized controlled trials in MEDLINE: ten years on. Journal of the Medical Library Association 2006;94(2):130-6.

\section{GRADE 2013}

Schünemann H, Brożek J, Guyatt G, Oxman A, editors The GRADE Working Group. GRADE Handbook for grading quality of evidence and strength of recommendations. gdt.gradepro.org/ app/handbook/handbook.html (initially accessed 2013).

\section{GRADEpro GDT [Computer program]}

McMaster University (developed by Evidence Prime) GRADEpro GDT. Version accessed prior to 11 July 2019. Hamilton (ON): McMaster University (developed by Evidence Prime).Available at gradepro.org.

\section{Gragoudas 2004}

Gragoudas ES, Adamis AP, Cunningham ET Jr, Feinsod M, Guyer DR. Pegaptanib for neovascular age-related macular degeneration. New England Journal of Medicine 2004;351(27):2805-16.

\section{Gregori 2009}

Gregori NZ, Rattan GH, Rosenfeld PJ, Puliafito CA, Feuer W, Flynn HW Jr, et al. Safety and efficacy of intravitreal bevacizumab (avastin) for the management of branch and hemiretinal vein occlusion. Retina 2009;29(7):913-25.

\section{Gunduz 2008}

Gunduz K, Bakri SJ. Intravitreal bevacizumab for macular oedema secondary to branch retinal vein occlusion. Eye 2008;22(9):1168-71.

\section{Haller 2010}

Haller JA, Bandello F, Belfort R Jr, Blumenkranz MS, Gillies M, Heier J, et al. Randomized, sham-controlled trial of dexamethasone intravitreal implant in patients with macular edema due to retinal vein occlusion. Ophthalmology 2010;117(6):1134-46.

\section{Hara 2010}

Hara S, Sakuraba T, Kataoka H, Yanagihashi S, Saitou K, Noda Y. Effect of repeated intravitreal bevacizumab injections for secondary macular edema of branch retinal vein occlusion. Nihon Ganka Gakkai Zasshi 2010;114(12):1013-8.

\section{Higgins 2019}

Higgins JPT, Savović J, Page MJ, Elbers RG, Sterne JAC. Chapter 8: Assessing risk of bias in a randomized trial. In: Higgins JPT, Thomas J, Chandler J, Cumpston M, Li T, Page MJ, Welch VA (editors). Cochrane Handbook for Systematic Reviews of Interventions version 6.0 (updated July 2019). Cochrane, 2019. Available from www.training.cochrane.org/handbook. 


\section{Hoeh 2009}

Hoeh AE, Ach T, Schaal KB, Scheuerle AF, Dithmar S. Long-term follow-up of OCT-guided bevacizumab treatment of macular edema due to retinal vein occlusion. Graefe's Archive for Clinical and Experimental Ophthalmology 2009;247(12):1635-41.

\section{Hou 2009}

Hou J, Tao Y, Jiang YR, Li XX, Gao L. Intravitreal bevacizumab versus triamcinolone acetonide for macular edema due to branch retinal vein occlusion: a matched study. Chinese Medical Journal 2009;122(22):2695-9.

\section{Hung 2010}

Hung KH, Lee SM, Lee SY, Lee FL, Yang CS. Intravitreal bevacizumab (avastin) in the treatment of macular edema associated with perfused retinal vein occlusion. Journal of Ocular Pharmacology and Therapeutics 2010;26(1):85-90.

\section{Jaissle 2009}

Jaissle GB, Leitritz M, Gelisken F, Ziemssen F, Bartz-Schmidt KU, Szurman P. One-year results after intravitreal bevacizumab therapy for macular edema secondary to branch retinal vein occlusion. Graefe's Archive for Clinical and Experimental Ophthalmology 2009;247(1):27-33.

\section{Jaissle 2011}

Jaissle GB, Szurman P, Feltgen N, Spitzer B, Pielen A, Rehak M, et al. Predictive factors for functional improvement after intravitreal bevacizumab therapy for macular edema due to branch retinal vein occlusion. Graefe's Archive for Clinical and Experimental Ophthalmology 2011;249(2):183-92.

\section{Klein 2000}

Klein R, Klein BE, Moss SE, Meuer SM. The epidemiology of retinal vein occlusion: the Beaver Dam Eye Study. Transactions of the American Ophthalmological Society 2000;98:133-41.

\section{Klein 2008}

Klein R, Moss SE, Meuer SM, Klein BE. The 15-year cumulative incidence of retinal vein occlusion: the Beaver Dam Eye Study. Archives of Ophthalmology 2008;126(4):513-8.

\section{Kondo 2009}

Kondo M, Kondo N, Ito Y, Kachi S, Kikuchi M, Yasuma TR, et al. Intravitreal injection of bevacizumab for macular edema secondary to branch retinal vein occlusion:results after 12 months and multiple regression analysis. Retina 2009;29(9):1242-8

\section{Kourlas 2007}

Kourlas $\mathrm{H}$, Abrams P. Ranibizumab for the treatment of neovascular age-related macular degeneration: a review. Clinical Therapeutics 2007;29(9):1850-61.

\section{Kreutzer 2008}

Kreutzer TC, Alge CS, Wolf AH, Kook D, Burger J, Strauss R, et al. Intravitreal bevacizumab for the treatment of macular oedema secondary to branch retinal vein occlusion. British Journal of Ophthalmology 2008;92(3):351-5.

\section{Kriechbaum 2008}

Kriechbaum K, Michels S, Prager F, Georgopoulos M, Funk M, Geitzenauer W, et al. Intravitreal Avastin for macular oedema secondary to retinal vein occlusion: a prospective study. British Journal of Ophthalmology 2008;92(4):518-22.

\section{McIntosh 2007}

McIntosh RL, Mohamed Q, Saw SM, Wong TY. Interventions for branch retinal vein occlusion: an evidence-based systematic review. Ophthalmology 2007;114(5):835-54.

\section{Meander 2014}

Meader N, King K, Llewellyn A, Norman G, Brown J, Rodgers M, et al. A checklist designed to aid consistency and reproducibility of GRADE assessments: development and pilot validation. Systematic Reviews 2014;3:82. [DOI: 10.1186/2046-4053-3-82]

\section{Mehany 2010}

Mehany SA. Early Avastin management in acute retinal vein occlusion. Saudi Journal of Ophthalmology 2010;24(3):87-94.

\section{Mitchell 1996}

Mitchell P, Smith W, Chang A. Prevalence and associations of retinal vein occlusion in Australia. The Blue Mountains Eye Study. Archives of Ophthalmology 1996;114(10):1243-7.

\section{Mitchell 2011}

Mitchell P. A systematic review of the efficacy and safety outcomes of anti-VEGF agents used for treating neovascular age-related macular degeneration: comparison of ranibizumab and bevacizumab. Current Medical Research and Opinion 2011;27(7):1465-75.

\section{Noma 2006}

Noma H, Minamoto A, Funatsu H, Tsukamoto H, Nakano K, Yamashita $\mathrm{H}$, et al. Intravitreal levels of vascular endothelial growth factor and interleukin- 6 are correlated with macular edema in branch retinal vein occlusion. Graefe's Archive for Clinical and Experimental Ophthalmology 2006;244(3):309-15.

\section{Ozaki 1997}

Ozaki H, Hayashi H, Vinores SA, Moromizato Y, Campochiaro PA, Oshima K. Intravitreal sustained release of VEGF causes retinal neovascularization in rabbits and breakdown of the bloodretinal barrier in rabbits and primates. Experimental Eye Research 1997;64(4):505-17.

\section{Pai 2007}

Pai SA, Shetty R, Vijayan PB, Venkatasubramaniam G, Yadav NK, Shetty BK, et al. Clinical, anatomic, and electrophysiologic evaluation following intravitreal bevacizumab for macular edema in retinal vein occlusion. American Journal of Ophthalmology 2007;143(4):601-6.

\section{Pece 2011}

Pece A, Isola V, Piermarocchi S, Calori G. Efficacy and safety of anti-vascular endothelial growth factor (VEGF) therapy with intravitreal ranibizumab (Lucentis) for naive retinal vein occlusion: 1-year follow-up. British Journal of Ophthalmology 2011;95(1):56-68. 


\section{Prager 2009}

Prager F, Michels S, Kriechbaum K, Georgopoulos M, Funk M, Geitzenauer W, et al. Intravitreal bevacizumab (Avastin) for macular oedema secondary to retinal vein occlusion: 12 month results of a prospective clinical trial. British Journal of Ophthalmology 2009;93(4):452-6.

\section{Presta 1997}

Presta LG, Chen H, O'Connor SJ, Chisholm V, Meng YG, Krummen L, et al. Humanization of an anti-vascular endothelial growth factor monoclonal antibody for the therapy of solid tumors and other disorders. Cancer Research 1997;57(20):4593-9.

\section{Qian 2017}

Qian T, Zhao M, Xu X. Comparison between anti-VEGF therapy and corticosteroid or laser therapy for macular oedema secondary to retinal vein occlusion: a meta-analysis. Journal of Clinical Pharmacy and Therapeutics 2017;42(5):519-29.

\section{Rabena 2007}

Rabena MD, Pieramici DJ, Castellarin AA, Nasir MA, Avery RL. Intravitreal bevacizumab (Avastin) in the treatment of macular edema secondary to branch retinal vein occlusion. Retina 2007;27(4):419-25.

\section{Rehak 2008}

Rehak J, Rehak M. Branch retinal vein occlusion: pathogenesis, visual prognosis, and treatment modalities. Current Eye Research 2008;33(2):111-31.

\section{Rensch 2009}

Rensch F, Jonas JB, Spandau UH. Early intravitreal bevacizumab for non-ischaemic branch retinal vein occlusion. Ophthalmologica 2009;223(2):124-7.

\section{Review Manager 2014 [Computer program]}

Nordic Cochrane Centre, The Cochrane Collaboration Review Manager 5 (RevMan 5). Version 5.3. Copenhagen: Nordic Cochrane Centre, The Cochrane Collaboration, 2014.

\section{Rogers 2010a}

Rogers SL, McIntosh RL, Lim L, Mitchell P, Cheung N, Kowalski JW, et al. Natural history of branch retinal vein occlusion: an evidence-based systematic review. Ophthalmology 2010;117(6):1094-101.

\section{Rogers 2010b}

Rogers S, McIntosh RL, Cheung N, Lim L, Wang JJ, Mitchell P, et al. The prevalence of retinal vein occlusion: pooled data from population studies from the United States, Europe, Asia, and Australia. Ophthalmology 2010;117(2):313-9.

\section{Rosenfeld 2006}

Rosenfeld PJ, Brown DM, Heier JS, Boyer DS, Kaiser PK, Chung CY, et al. Ranibizumab for neovascular age-related macular degeneration. New England Journal of Medicine 2006;355(14):1419-31.

\section{Rouvas 2010}

Rouvas A, Petrou P, Ntouraki A, Douvali M, Ladas I, Vergados I. Intravitreal ranibizumab (Lucentis) for branch retinal vein occlusion-induced macular edema: nine-month results of a prospective study. Retina 2010;30(6):893-902.

\section{Schaal 2007}

Schaal KB, Hoh AE, Scheuerle A, Schutt F, Dithmar S. Bevacizumab for the treatment of macular edema secondary to retinal vein occlusion. Ophthalmologe 2007;104(4):285-9.

\section{Scott 2009}

Scott IU, Ip MS, VanVeldhuisen PC, Oden NL, Blodi BA, Fisher M, et al. A randomized trial comparing the efficacy and safety of intravitreal triamcinolone with standard care to treat vision loss associated with macular Edema secondary to branch retinal vein occlusion: the Standard Care vs Corticosteroid for Retinal Vein Occlusion (SCORE) study report 6. Archives of Ophthalmology 2009;127(9):1115-28.

\section{Shilling 1976}

Shilling JS, Kohner EM. New vessel formation in retinal branch vein occlusion. British Journal of Ophthalmology 1976;60(12):810-5.

\section{Stahl 2007}

Stahl A, Agostini H, Hansen LL, Feltgen N. Bevacizumab in retinal vein occlusion-results of a prospective case series. Graefe's Archive for Clinical and Experimental Ophthalmology 2007;245(10):1429-36.

\section{Wong 2005}

Wong TY, Larsen EK, Klein R, Mitchell P, Couper DJ, Klein BE, et al. Cardiovascular risk factors for retinal vein occlusion and arteriolar emboli: the Atherosclerosis Risk in Communities \& Cardiovascular Health studies. Ophthalmology 2005;112(4):540-7.

\section{Xu 2007}

Xu L, Liu WW, Wang YX, Yang H, Jonas JB. Retinal vein occlusions and mortality: the Beijing Eye Study. American Journal of Ophthalmology 2007;144(6):972-3.

\section{Yasuda 2010}

Yasuda M, Kiyohara Y, Arakawa S, Hata Y, Yonemoto K, Doi Y, et al. Prevalence and systemic risk factors for retinal vein occlusion in a general Japanese population: the Hisayama study. Investigative Ophthalmology and Visual Science 2010;51(6):3205-9.

\section{References to other published versions of this review Mitry 2011}

Mitry D, Bunce C, Charteris D. Anti-vascular endothelial growth factor for macular oedema secondary to branch retinal vein occlusion. Cochrane Database of Systematic Reviews 2011, Issue 12. [DOI: 10.1002/14651858.CD009510] 


\section{Mitry 2013}

Mitry D, Bunce C, Charteris D. Anti-vascular endothelial growth factor for macular oedema secondary to branch retinal vein occlusion. Cochrane Database of Systematic Reviews 2013, Issue 1. [DOI: 10.1002/14651858.CD009510.pub2]

CHARACTERISTICS OF STUDIES

Characteristics of included studies [ordered by study ID]

Bandello 2018

\section{Study characteristics}

Methods

Study design: randomised controlled trial

Eyes: 1 eye per participant although there is no description of how the eye was chosen in people with bilateral disease

Participants

Country: 42 sites in France, Germany, Israel, Italy, Spain, and the UK

Number of people randomised: 307 (307 eyes)

Number (\%) of people followed-up: 251 (251 eyes) (81.8\%)

Average age: 67.0 years (range unknown) (SD 11.4) (minimum 18 years)

Sex: $41.7 \%$ female

Inclusion criteria

- Diagnosis of branch retinal vein occlusion in at least 1 eye

- Age 18 years and over

- Visual acuity between $20 / 400$ to $20 / 40$

\section{Exclusion criteria}

- Active eye infection

- Ocular hypertension which is not controlled on monotherapy (1 medication)

- Anticipated need for eye surgery during the study

- Cataract surgery in either eye within 3 months

- Eye surgery including laser of any type within 6 months

- Anti-VEGF treatment in either eye (e.g. Lucentis ${ }^{\circledR}$ ) within 3 months or systemic anti-VEGF treatment (e.g. Avastin) within 6 months

- Use of ocular steroids within 3 months

- Use of steroids (except for inhaled or intranasal) within 1 month or anticipated use during the study

\section{Intervention}

- Dexamethasone implant $(n=154)$

\section{Comparator}

- Ranibizumab ( $n=153)$

\section{Treatment regimen}

- Injection of Ozurdex ${ }^{\circledast}(n=154)$ (dexamethasone intravitreal implant) into the study eye on day 1 and month 5. Participants may receive up to 1 additional treatment at month 10 or 11 thereafter.

- Injection of Lucentis ${ }^{\circledast}(n=153)$ (ranibizumab) into the study eye on day 1 and monthly for 5 months. Participants will receive additional treatment thereafter based on re-treatment criteria

\section{Co-intervention: none}


Sample size calculation: Applying a non-inferiority margin of five letters and assuming a common standard deviation of 10 letters for a study with $80 \%$ power, the number of participants required for each treatment arm was 176 . Based on an anticipated dropout rate of $10 \%$, the planned study enrolment was 400 participants.

Primary
- Change from baseline in best-corrected visual acuity (BCVA)
Secondary
- Change from baseline in central retinal subfield thickness using optical coherence tomography (OCT)
- Percentage of participants with 15 or more letter Improvement in BCVA
- Percentage of participants with 15 or more letter decrease in BCVA
- Time to BCVA improvement of 15 or more letters
- Change from baseline in National Eye Institute Visual Functioning Questionnaire-25 (VFQ-25)
Follow-up: 12 months

Declaration of interest: Allergan is the study sponsor and responsible party

Trial registration ID: NCT01427751

\section{Risk of bias}

\begin{tabular}{|c|c|c|}
\hline Bias & Authors' judgement & Support for judgement \\
\hline $\begin{array}{l}\text { Random sequence genera- } \\
\text { tion (selection bias) }\end{array}$ & Unclear risk & Not stated \\
\hline $\begin{array}{l}\text { Allocation concealment } \\
\text { (selection bias) }\end{array}$ & Unclear risk & Not stated \\
\hline $\begin{array}{l}\text { Blinding of participants } \\
\text { and personnel (perfor- } \\
\text { mance bias) } \\
\text { All outcomes }\end{array}$ & High risk & No masking of participants or personnel \\
\hline $\begin{array}{l}\text { Blinding of outcome as- } \\
\text { sessment (detection bias) } \\
\text { All outcomes }\end{array}$ & High risk & $\begin{array}{l}\text { "Patients and investigators were not masked to treatment assignment, which } \\
\text { introduces potential bias." }\end{array}$ \\
\hline $\begin{array}{l}\text { Incomplete outcome data } \\
\text { (attrition bias) } \\
\text { All outcomes }\end{array}$ & High risk & $\begin{array}{l}42(27.2 \%) \text { did not complete } 12 \text { months' follow-up in the dexamethasone arm. } \\
\text { The most common reason was adverse event (raised IOP) } \\
14(9.2 \%) \text { did not complete } 12 \text { months' follow-up in the ranibizumab arm }\end{array}$ \\
\hline $\begin{array}{l}\text { Selective reporting (re- } \\
\text { porting bias) }\end{array}$ & Low risk & All outcomes reported as planned \\
\hline Other bias & Unclear risk & Only 307 eyes recruited from initial plan of 400 \\
\hline
\end{tabular}




\section{Study characteristics}

Methods Study design: randomised controlled trial

Eyes: 1 eye was chosen as the study eye for each participant

Participants

Country: 33 centres in China and Far East

Number of people randomised: 283 (283 eyes)

Number (\%) of people followed-up: 266 (266 eyes) (94.0\%)

Average age: 56.9 years (range unknown)

Sex: $49.1 \%$ female

Inclusion criteria

- "Patients with visual impairment secondary to branch retinal vein occlusion (BRVO) with a BCVA between 19 and 73 letters in one eye and at least 35 letters in the other eye"

\section{Exclusion criteria}

- Pregnant or nursing women or women of child bearing potential unless using an effective contraception

- Stroke or myocardial infarction within 3 months prior to study

- History of malignancy within the past 5 years

- Uncontrolled hypertension

- Active infection or inflammation in any eye

- Use of corticosteroids for at least 30 days in the last 6 months

- Treatment with anti-angiogenic drugs in any eye within last 3 months

- Panretinal or focal/grid laser photocoagulation within the last few month"

Interventions

\section{Intervention}

- Ranibizumab $0.5 \mathrm{mg}(\mathrm{n}=190)$

\section{Comparator}

- Sham injection $(n=93)$

\section{Treatment regimen}

- "Patients received monthly consecutive intravitreal injections of ranibizumab until stable maximal visual acuity was achieved, followed by individualized, stabilization criteria-driven pro re nata (PRN) regimen."

\section{Co-intervention}

- "Patients in the sham group received monthly sham injections up to month 2, followed by the PRN regimen up to month 5. From month 6, patients could receive ranibizumab PRN."

Sample size calculation: None shown

Outcomes Primary outcome

- Mean change from baseline BCVA at month 6

\section{Secondary outcomes}

- Mean change from baseline BCVA at month 12

- Number of participants with a BCVA improvement of $\geq 5, \geq 10, \geq 15$, and $\geq 30$ letters over time 
BLOSSOM (Continued)

- Proportion of participants who lost $\geq 15$ letters from baseline

- Mean change from baseline CRT over time

- Change in total area of fluorescein leakage from baseline over time

- Change from baseline in NEI-VFQ-25 composite and subscale scores

Follow-up: 6 and 12 months

Notes

Date study conducted: November 2013 to March 2016

Funding source: Novartis Pharmaceuticals

Declaration of interest: Novartis Pharmaceuticals provided funding for the study and is the study sponsor

Trial registration ID: NCT01976338

\begin{tabular}{|c|c|c|}
\hline \multicolumn{3}{|l|}{ Risk of bias } \\
\hline Bias & Authors' judgement & Support for judgement \\
\hline $\begin{array}{l}\text { Random sequence genera- } \\
\text { tion (selection bias) }\end{array}$ & Unclear risk & No information given on ClinicalTrials.gov or conference abstract \\
\hline $\begin{array}{l}\text { Allocation concealment } \\
\text { (selection bias) }\end{array}$ & Unclear risk & No information given on ClinicalTrials.gov or conference abstract \\
\hline $\begin{array}{l}\text { Blinding of participants } \\
\text { and personnel (perfor- } \\
\text { mance bias) } \\
\text { All outcomes }\end{array}$ & Low risk & Double-masked sham-injection study \\
\hline $\begin{array}{l}\text { Blinding of outcome as- } \\
\text { sessment (detection bias) } \\
\text { All outcomes }\end{array}$ & Unclear risk & No information given on ClinicalTrials.gov or conference abstract \\
\hline $\begin{array}{l}\text { Incomplete outcome data } \\
\text { (attrition bias) } \\
\text { All outcomes }\end{array}$ & Low risk & $\begin{array}{l}13(6.8 \%) \text { of } 190 \text { ranibizumab participants failed to complete } 12 \text { months' fol- } \\
\text { low-up. } 5 \text { of these were due to adverse events, } 5 \text { were due to subject choice } \\
\text { and } 3 \text { were lost to follow-up. } \\
4(4.3 \%) \text { of } 93 \text { sham participants failed to complete } 12 \text { months' follow-up. } 1 \text { of } \\
\text { these was due to adverse events, } 2 \text { were due to withdrawal by subject and } 1 \\
\text { was physician decision. }\end{array}$ \\
\hline $\begin{array}{l}\text { Selective reporting (re- } \\
\text { porting bias) }\end{array}$ & Low risk & All primary and secondary outcome results reported \\
\hline Other bias & Low risk & $\begin{array}{l}\text { Participants in the sham arm were able to receive ranibizumab from month } 6 \text {. } \\
\text { This group received a mean of } 3.6 \text { ranibizumab injections between month } 6 \\
\text { and month } 12 \text {. }\end{array}$ \\
\hline
\end{tabular}

\section{BRIGHTER}

\section{Study characteristics}

Methods

Study design: randomised controlled trial 
Eyes: 1 eye was chosen as the study eye for each participant. If both eyes were eligible at screening and baseline, the study eye was selected on the basis of the investigator's discretion.

\section{Participants}

\section{Country: 17 countries worldwide (82 centres)}

Number of people randomised: 455 (455 eyes)

Number (\%) of people followed up: $380(83.5 \%)$ at 24 months

Average age: 66.3 years (range unknown)

\section{Inclusion criteria}

- Age 18 years and over

- BCVA letter score at screening and baseline between 73 and 19 Early Treatment Diabetic Retinopathy Study (ETDRS) letters, inclusive (approximate Snellen equivalent of 20/40 and 20/400).

\section{Exclusion criteria}

- Stroke or myocardial infarction $<3$ months before screening

- Uncontrolled blood pressure (>160/>100 mmHg) at screening or baseline

- Periocular or ocular infection or inflammation at screening or baseline

- Intravitreal anti-VEGF injections 3 months before baseline and systemic anti-VEGF injections 6 months before baseline

- Uncontrolled glaucoma (intraocular pressure $30 \mathrm{mmHg}$ on medication or according to the investigator's judgment) at the time of screening or baseline or diagnosed within 6 months before baseline

- Laser photocoagulation for macular oedema 4 months before baseline; intraocular or periocular corticosteroid use 3 months before baseline

- Known hypersensitivity to ranibizumab or any component of the ranibizumab formulation or fluorescein

- Pregnant or nursing women

Interventions

\section{Intervention}

- Ranibizumab $(n=183)$

\section{Comparator}

- $\operatorname{Laser}(\mathrm{n}=92)$

\section{Treatment regimen}

- Ranibizumab: participants received ranibizumab monthly (minimum 3 injections) until stabilisation of visual acuity followed by re-treatment when visual acuity dropped with evidence of disease activity on OCT or otherwise

- Laser: participants received macular laser at investigator's discretion, with minimum 4 months between laser treatments. From month 6 , participants could also receive ranibizumab as required (66 of 92 participants received ranibizumab).

\section{Co-intervention}

- This study had a treatment arm ranibizumab $0.5 \mathrm{mg}$ with laser that was not relevant to this review and we will not consider it further

Sample size calculation: By assuming a standard deviation of 14 letters, and estimating a dropout rate of approximately $10 \%$, a sample size of 180 participants in the ranibizumab and 90 participants in the laser arm was considered. This sample size had a power of $90.5 \%$ to detect a treatment difference of 7 or more letters at a 1-sided alpha level of 0.0125 for an unstratified analysis. 
BRIGHTER (Continued)

- Mean change in BCVA from baseline at month 6 and 24 in participants treated with ranibizumab with or without laser versus laser alone.

\section{Secondary outcomes}

- To compare the efficacy of ranibizumab with or without laser versus laser alone for

* the mean average change in BCVA from baseline;

* the proportion of participants with a BCVA improvement of 10/15/30 letters;

* the proportion of participants attaining a BCVA of 73 letters;

* the mean change in central reading centre (CRC) assessed central subfield thickness (CSFT) from baseline.

- To assess the treatment exposure of ranibizumab and laser

- To evaluate the safety profile of ranibizumab over 6 months

Follow-up: 24 months

Notes

Date study conducted: May 2012 to May 2015

Funding source: Novartis Pharmaceuticals

Declaration of interest: study funded and managed by Novartis, who provided medical writing and editorial assistance for the study.

Trial registration ID: NCT01599650

\section{Risk of bias}

\begin{tabular}{|c|c|c|}
\hline Bias & Authors' judgement & Support for judgement \\
\hline $\begin{array}{l}\text { Random sequence genera- } \\
\text { tion (selection bias) }\end{array}$ & Low risk & $\begin{array}{l}\text { "Randomization list was generated using a validated system that automates } \\
\text { the random assignment of treatment arms to randomization numbers in the } \\
\text { specified ratio" }\end{array}$ \\
\hline $\begin{array}{l}\text { Allocation concealment } \\
\text { (selection bias) }\end{array}$ & Unclear risk & No comment made in papers or on ClinicalTrials.gov \\
\hline $\begin{array}{l}\text { Blinding of participants } \\
\text { and personnel (perfor- } \\
\text { mance bias) } \\
\text { All outcomes }\end{array}$ & High risk & No masking of investigators or participants \\
\hline $\begin{array}{l}\text { Blinding of outcome as- } \\
\text { sessment (detection bias) } \\
\text { All outcomes }\end{array}$ & Low risk & Visual acuity assessors were masked \\
\hline $\begin{array}{l}\text { Incomplete outcome data } \\
\text { (attrition bias) } \\
\text { All outcomes }\end{array}$ & High risk & $\begin{array}{l}\text { There was more discontinuation in the laser arm }(29.3 \%) \text { than in the } \\
\text { ranibizumab arm (12.0\%) }\end{array}$ \\
\hline $\begin{array}{l}\text { Selective reporting (re- } \\
\text { porting bias) }\end{array}$ & Low risk & $\begin{array}{l}\text { All of the study's primary and secondary outcomes have been reported as pre- } \\
\text { specified. }\end{array}$ \\
\hline Other bias & High risk & $\begin{array}{l}\text { From month } 6 \text {, participants in the laser arm were able to receive ranibizumab, } \\
\text { and } 66(71.7 \%) \text { of } 92 \text { did. }\end{array}$ \\
\hline
\end{tabular}


COMRADE-B

\section{Study characteristics}

Methods Study design: randomised controlled trial

Eyes: "For all patients, one eye was selected and treated as the study eye. If both the eyes were eligible, then the eye with the worse VA (assessed at visit 1) was selected, unless the investigator deemed that the fellow eye was more appropriate for study treatment."

\section{Participants}

Country: "74 sites across Germany, Great Britain, the Czech Republic, Poland and Hungary."

Number of people randomised: 244 (244 eyes)

Number (\%) of people followed-up: 215 (215 eyes) (88.1\%)

Average age: 65.6 years (range unknown) (SD 10.5)

Sex: $54.5 \%$ female

\section{Inclusion criteria}

- "Inclusion criteria were diagnosis of visual impairment due to macular oedema secondary to BRVO at maximum 6 months prior to screening and best-corrected visual acuity (BCVA; study eye) of 20/40 (6/12 m) to 20/400 (6/120 m) using Early Treatment Diabetic Retinopathy Study (ETDRS)-like VA testing charts."

\section{Exclusion criteria}

- "(i) history of (a) radial optic neurotomy or sheathotomy in the study eye, (b) the presence of either dry or wet age-related macular degeneration in the study eye, (c) hypersensitivity to any of the study drugs or to drugs with similar chemical structures, (d) allergy to fluorescein; (ii) central subfield retinal thickness (CSRT) <250 lm in the study eye; (iii) prior episodes of RVO in the study eye; (iv) anti-VEGF treatment in the study eye or the fellow eye within 3 months prior to baseline; (v) panretinal scatter photocoagulation or sector laser photocoagulation performed within 3 months before baseline or anticipated to be performed in the 4 months following randomization; (vi) use of intraocular corticosteroid within 6 months before baseline; (vii) IOP of $\geq 30 \mathrm{mmHg}$ or uncontrolled glaucoma; patients could be rescreened after 1 month if they had undergone glaucoma treatment; and (viii) a history of cerebral vascular accident or myocardial infarction within 12 months prior to baseline."

Interventions

\section{Intervention}

- Ranibizumab $(n=126)$

\section{Comparator}

- Dexamethasone $(n=118)$

\section{Treatment regimen}

- Ranibizumab arm $(n=126)$ : "Patients received 3 monthly ranibizumab $0.5 m g$ injections at the start of the study until a stable VA was reached (defined as stable or no change in VA for three consecutive monthly assessments), followed by PRN treatment. Thereafter, patients were monitored monthly for VA. Monthly treatment was resumed if there was a loss of VA due to disease activity, and was continued until stable VA was reached again for three consecutive monthly assessments."

- Dexamethasone arm $(n=118)$ : "Patients received a single sustained release intravitreal $0.7 \mathrm{mg}$ dexamethasone intravitreal implant. Thereafter, they received monthly sham injections until month 3 followed by a PRN regimen. The sham injections consisted of empty sterile syringes without needles, and the procedure involved applying pressure against the globe of the eye to mimic the injection procedure of the ranibizumab group."

\section{Co-intervention: none}

Sample size calculation: A sample size of 108 participants in each of the treatment groups was considered to have $90 \%$ power to detect a significant difference on a two-sided, $5 \%$ significance level, if the 
COMRADE-B (Continued)

true difference was six letters with a common standard deviation of 13.5. To compensate for dropouts and other protocol violations, 120 participants were considered in each of the treatment groups.

Primary outcome
- "mean average change in BCVA from baseline to month 1 through month 6"
Secondary outcomes
- "(a) mean change in BCVA and CSRT at month 6
- (b) proportion of participants with a BCVA gain or loss of $\geq 15 / \geq 10 / \geq 5$
- letters at month 6,
- (c) time to achieve a significant improvement in BCVA, defined as $\geq 15$ letters;
- (d) rate in IOP rise from baseline to month 6"

Follow-up: 6 months

Date study conducted: July 2011 to June 2013
Funding source: Novartis Pharmaceuticals
Declaration of interest: study director is employed by Novartis Pharmaceuticals
Trial registration ID: NCT01396057
Visual acuity improved until month 3 in the dexamethasone arm but then got worse. The authors sug-
gested re-treatment before 6 months would produce better results.

\section{Risk of bias}

\begin{tabular}{|c|c|c|}
\hline Bias & Authors' judgement & Support for judgement \\
\hline $\begin{array}{l}\text { Random sequence genera- } \\
\text { tion (selection bias) }\end{array}$ & Low risk & $\begin{array}{l}\text { "A randomization list was produced using a validated system that randomly } \\
\text { assigned the treatment arms to randomization numbers in the specified ratio" }\end{array}$ \\
\hline $\begin{array}{l}\text { Allocation concealment } \\
\text { (selection bias) }\end{array}$ & Unclear risk & No information available on whether allocation was concealed \\
\hline $\begin{array}{l}\text { Blinding of participants } \\
\text { and personnel (perfor- } \\
\text { mance bias) } \\
\text { All outcomes }\end{array}$ & Low risk & $\begin{array}{l}\text { "A minimum of two investigators were involved, per study site, to fulfil the } \\
\text { masking requirements. The injecting physician was unmasked and performed } \\
\text { the study drug administrations as per the protocol; however, they were not in- } \\
\text { volved in any other aspects of the study and were not allowed to communicate } \\
\text { the details of the treatment to anyone. Patients were blinded and sham injec- } \\
\text { tions were given to the dexamathasone group after the baseline injection." }\end{array}$ \\
\hline
\end{tabular}

Blinding of outcome as- Low risk sessment (detection bias) All outcomes "All ocular assessments were carried out by the evaluating physician who was
masked to the treatment assignment."

\begin{tabular}{|c|c|c|}
\hline $\begin{array}{l}\text { Incomplete outcome data } \\
\text { (attrition bias) } \\
\text { All outcomes }\end{array}$ & High risk & $\begin{array}{l}\text { In the ranibizumab arm, } 91.3 \% \text { completed } 6 \text { months' follow-up. This was only } \\
84.7 \% \text { in the dexamethasone arm. The dexamethasone arm had } 6 \text { participant } \\
\text { withdrawals due to inadequate response to treatment and } 6 \text { withdrawals due } \\
\text { to adverse events (the nature of these is not clear). }\end{array}$ \\
\hline
\end{tabular}

\begin{tabular}{lll}
\hline $\begin{array}{l}\text { Selective reporting (re- } \\
\text { porting bias) }\end{array}$ & Low risk & $\begin{array}{l}\text { All of the study's primary and secondary outcomes have been reported as pre- } \\
\text { specified. }\end{array}$ \\
\hline Other bias & High risk & $\begin{array}{l}\text { The trial design forbids re-treatment with dexamethasone within } 6 \text { months. } \\
\text { Re-treatment earlier in this arm may have produced better results. }\end{array}$ \\
\hline
\end{tabular}


Higashiyama 2013

\section{Study characteristics}

Methods Study design: randomised controlled trial

Eyes: "Forty-three eyes of 43 consecutive patients". There is no mention of bilateral disease

\section{Participants}

\section{Country: Japan}

Number of people randomised: 43 (43 eyes)

Number (\%) of people followed-up: 36 (36 eyes) (83.7\%)

Average age: 68.4 years (range unknown) (minimum 40 years)

Sex: $60.5 \%$ female

\section{Inclusion criteria}

- Participant age of 40 years or older

- Time from the onset of symptoms to study entry $<12$ months

- Best-corrected visual acuity (BCVA) of 0.5 or less

- Central retinal thickness (CRT) of 300 microns or more

\section{Exclusion criteria}

- Participants who had been treated previously for BRVO including laser treatment or vitrectomy

- Glaucoma or intraocular hypertension (21 mmHg or higher)

- Inflammatory disease

- Diabetic retinopathy

- History of stroke

- Uncontrolled myocardial disease

- Kidney failure

- History of thromboembolic event

- Triamcinolone $4 \mathrm{mg}(\mathrm{n}=21)$

\section{Comparator}

- Bevacizumab $(n=22)$

\section{Treatment regimen}

- No additional treatments were administered for 3 months after the initial injection; additional injections were administered when macular oedema recurred between 3 and 12 months after the initial injection.

Co-intervention: none

Sample size calculation: none presented

- Variation on a logarithm of the minimum angle of resolution and variation on a central retinal thickness 1 month, 3 months, 6 months, 9 months, and 12 months after intravitreal injection.

\section{Secondary outcome}


- Fluorescin angiography before and 1 month, 3 months, 6 months, 9 months, and 12 months after intravitreal injection.

Follow-up: 12 months

Notes

Date study conducted: October 2006 onwards

Funding source: Ministry of Education, Culture, Sports, Science and Technology of Japan and Ministry of Health, Labour and Welfare.

Declaration of interest: none stated

Trial registration ID: UMIN00 0001546

\section{Risk of bias}

\begin{tabular}{lll}
\hline Bias & Authors' judgement & Support for judgement \\
\hline $\begin{array}{l}\text { Random sequence genera- } \\
\text { tion (selection bias) }\end{array}$ & Unclear risk & $\begin{array}{l}\text { "The doctor who designed and conducted this study (O.S.) was responsible for } \\
\text { randomization and random allocation performed by the others on the day that } \\
\text { the patients received an intravitreal injection." }\end{array}$ \\
\hline $\begin{array}{l}\text { Allocation concealment } \\
\text { (selection bias) }\end{array}$ & Low risk & 'Envelope method' used for randomisation \\
\hline $\begin{array}{l}\text { Blinding of participants } \\
\begin{array}{l}\text { and personnel (perfor- } \\
\text { mance bias) } \\
\text { All outcomes }\end{array}\end{array}$ & High risk & $\begin{array}{l}\text { Treating doctors were not masked. Participants were masked although the na- } \\
\text { ture of triamcinolone and bevacizumab injections are different symptomati- } \\
\text { cally so this masking is likely compromised }\end{array}$
\end{tabular}

\begin{tabular}{|c|c|c|}
\hline $\begin{array}{l}\text { Blinding of outcome as- } \\
\text { sessment (detection bias) } \\
\text { All outcomes }\end{array}$ & High risk & Outcome assessors not masked \\
\hline \multirow[t]{3}{*}{$\begin{array}{l}\text { Incomplete outcome data } \\
\text { (attrition bias) } \\
\text { All outcomes }\end{array}$} & Unclear risk & $\begin{array}{l}3(14.2 \%) \text { triamcinolone did not complete } 12 \text { months' follow-up: } 1 \text { was lost to } \\
\text { follow-up, whilst the other } 2 \text { discontinued due to adverse events (high IOP and } \\
\text { vitreous haemorrhage). }\end{array}$ \\
\hline & & $\begin{array}{l}4(18.2 \%) \text { bevacizumab participants were discontinued due to loss to fol- } \\
\text { low-up. All } 4 \text { participants had improvement in BCVA and OCT at final fol- } \\
\text { low-up. }\end{array}$ \\
\hline & & $\begin{array}{l}\text { All discontinued participants were not analysed in the 12-month results, re- } \\
\text { gardless of reason for discontinuation. }\end{array}$ \\
\hline $\begin{array}{l}\text { Selective reporting (re- } \\
\text { porting bias) }\end{array}$ & Low risk & $\begin{array}{l}\text { All primary outcomes reported. Secondary outcome (fluorescein angiogram } \\
\text { findings) is not reported but is not the subject of this review. }\end{array}$ \\
\hline Other bias & Unclear risk & None \\
\hline
\end{tabular}

RABAMES

\section{Study characteristics}

Methods

Study design: randomised controlled trial

Eyes: 1 eye per participant although there is no description of how the eye was chosen in participants with bilateral disease 
RABAMES (Continued)

Participants

Country: 4 centres in Germany

Number of people randomised: 30 (30 eyes)

Number (\%) of people followed-up: 30 (30 eyes) (100\%)

Average age: 66.3 years (range unknown) (SD 9.7) (minimum 18 years)

Sex: $50 \%$ female

\section{Inclusion criteria}

- Adults aged 18 years and older with chronic (> 3 months, $<18$ months) macular oedema secondary to branch retinal vein occlusion

- Participants who at baseline have a BCVA in the study eye between 20/320 and equivalent to 20/40 using an ETDRS chart

- All of the following characteristics as determined by fluorescein angiography and OCT.

- Evidence that the macular oedema extends under the geometric centre of the foveal avascular zone

- Evidence that the oedema is only secondary to BRVO (no other relevant ocular diseases, e. g. uveitis)

- Evidence that central retinal thickness is $>225 \mathrm{~lm}$

- Evidence that the oedema was suitable for BVOS laser criteria, that is, did not show macular ischaemia, central subretinal fibrosis or atrophy, or central persistent haemorrhage

\section{Exclusion criteria}

- Uveitis

- Neovascular glaucoma

- Neovascular age-related macular degeneration

- Diabetic retinopathy

- Diabetic maculopathy

- Ocular ischaemic syndrome

- Malignant systemic disease possibly associated with increased systemic VEGF levels (e.g. breast cancer)

- Prior treatment for macular oedema (e.g. laser, triamcinolone, vitrectomy, etc)

\section{Intervention}

- Ranibizumab $(\mathrm{n}=10)$

\section{Comparator}

- Grid-pattern laser photocoagulation $(n=10)$

\section{Treatment regimen}

- "During the 3-month treatment period, patients received either three monthly intravitreal ranibizumab injections, or up to two treatment sessions of macular laser photocoagulation or intravitreal ranibizumab combined with laser photocoagulation. No further laser or intravitreal ranibizumab treatment was planned during the observation period."

\section{Co-intervention: none}

A further combination group (ranibizumab plus laser) $(n=10)$ was also part of this study but does not fall within the remit of this review and will not be considered further.

Sample size calculation: none performed as study was planned as a proof-of-concept pilot study to acquire estimates of the efficacy of laser and ranibizumab. No significance level was fixed.

\section{Outcomes}

\section{Primary outcome}

Anti-vascular endothelial growth factor for macular oedema secondary to branch retinal vein occlusion (Review) Copyright (c) 2020 The Cochrane Collaboration. Published by John Wiley \& Sons, Ltd. 
- Mean change in BCVA (logMAR) from baseline at month 6

\section{Secondary outcomes}

- Mean change in BCVA from baseline to month 3

- Proportion of participants who gain $\geq 5,10,15$ letters of BSCVA from baseline to month 3 and 6

- Proportion of participants who lose less than 15 letters of BCVA from baseline to month 3 and 6

- Change in area and intensity of leakage from baseline to month 1, 3 and 6

- Mean change in central macular thickness (by OCT) from baseline to month 1, 3 and 6

- Mean change in central macular thickness (by OCT) from month 3 to 6

Follow-up: 6 months

Notes

Date study conducted: November 2007 to September 2010

Funding source: Norvartis Pharmaceuticals

Declaration of interest: Klinikum Ludwigshafen is the study sponsor. Novartis and Coordination Center for Clinical Studies, Mainz, Germany are the collaborators.

Trial registration ID: NCT00562406

Participants were treated for 3 months (day 0 to week 12 ) according to their assigned group followed by a 3-month observation period (weeks 12 to 24).

\section{Risk of bias}

\begin{tabular}{|c|c|c|}
\hline Bias & Authors' judgement & Support for judgement \\
\hline $\begin{array}{l}\text { Random sequence genera- } \\
\text { tion (selection bias) }\end{array}$ & Unclear risk & $\begin{array}{l}\text { "Randomization was performed by the coordinating study centre." No infor- } \\
\text { mation is given on how randomisation was achieved. }\end{array}$ \\
\hline $\begin{array}{l}\text { Allocation concealment } \\
\text { (selection bias) }\end{array}$ & Unclear risk & $\begin{array}{l}\text { Randomisation was performed by } 1 \text { of the } 4 \text { study centres, but no information } \\
\text { is given on how allocation concealment was ensured for the participants re- } \\
\text { cruited at this central study centre. }\end{array}$ \\
\hline $\begin{array}{l}\text { Blinding of participants } \\
\text { and personnel (perfor- } \\
\text { mance bias) } \\
\text { All outcomes }\end{array}$ & High risk & No masking of investigators or participants save for OCT assessment \\
\hline $\begin{array}{l}\text { Blinding of outcome as- } \\
\text { sessment (detection bias) } \\
\text { All outcomes }\end{array}$ & High risk & $\begin{array}{l}\text { Outcome visual acuity assessments were made by unmasked examiners but } \\
\text { OCT scans were evaluated by an independent retina specialist masked to the } \\
\text { individual treatment. }\end{array}$ \\
\hline $\begin{array}{l}\text { Incomplete outcome data } \\
\text { (attrition bias) } \\
\text { All outcomes }\end{array}$ & Low risk & $\begin{array}{l}\text { There were no participants lost to follow-up in either ranibizumab or laser } \\
\text { groups. } 1 \text { participant (combined ranibizumab and laser group) withdrew after } \\
\text { stroke but this group is not included in this review. }\end{array}$ \\
\hline $\begin{array}{l}\text { Selective reporting (re- } \\
\text { porting bias) }\end{array}$ & Low risk & $\begin{array}{l}\text { All outcomes reported except 'change in area and intensity of leakage from } \\
\text { baseline to month } 1,3 \text { and } 6 \text { ' }\end{array}$ \\
\hline Other bias & Low risk & None \\
\hline
\end{tabular}

\section{Study characteristics}

Anti-vascular endothelial growth factor for macular oedema secondary to branch retinal vein occlusion (Review) 
Ramezani 2012 (Continued)

Methods

Study design: randomised controlled trial

Eyes: 1 eye per participant although there is no description of how the eye was chosen in participants with bilateral disease

Country: Iran (single site)
Number of people randomised: 86 (86 eyes)
Number (\%) of people followed-up: 86 (86
Average age: 59 years (range 40 to 80 )
Sex: $48.8 \%$ female
Inclusion criteria
- Recent onset (less than 3 months) BRVO
Exclusion criteria
- Any previous intervention

Interventions

Intervention

- Bevacizumab $(n=43)$

Comparator

- Triamcinolone $(n=43)$

\section{Treatment regimen}

- Bevacizumab: "eyes received a prescheduled three monthly intravitreal injections of $1.25 \mathrm{mg} / 0.05 \mathrm{ml}$ bevacizumab"

- Triamcinolone: "two intravitreal injections of $2 \mathrm{mg} / 0.05 \mathrm{ml}$ triamcinolone acetonide, performed 2 months apart"

\section{Co-intervention: none}

Sample size calculation: To have a power of $95 \%$ to detect a 10 letter difference between the two groups, when the standard deviation is 12 letters and type I error was 0.05 , the sample size was calculated to be 39 eyes in each group. Considering a dropout rate of $10 \%, 43$ samples were recruited in each group.

\section{Outcomes}

\section{Primary outcome}

- Change in BCVA at 6 months

\section{Secondary outcome}

- Change in central macular thickness at 6 months

Follow-up: 6 months

Notes

Date study conducted: January to August 2010

Funding source: Shahid Beheshti University of Medical Sciences

Declaration of interest: Labbafinejad Medical Center is a collaborator

Trial registration ID: NCT01044329

\section{Risk of bias}

Anti-vascular endothelial growth factor for macular oedema secondary to branch retinal vein occlusion (Review) Copyright $\odot 2020$ The Cochrane Collaboration. Published by John Wiley \& Sons, Ltd. 
Ramezani 2012 (Continued)

Bias Authors' judgement Support for judgement

Random sequence genera- Low risk tion (selection bias)
"Randomization was performed using random block permutation method according to a computer generated randomization list. The block length varied randomly $(4,8) . "$

\begin{tabular}{ll}
\hline $\begin{array}{l}\text { Allocation concealment } \quad \text { Low risk } \\
\text { (selection bias) }\end{array}$ & $\begin{array}{l}\text { "Random allocation sequence was performed by a biostatistician. He put the } \\
\text { randomization sequence in numbered, labeled, concealed envelopes. When- } \\
\text { ever a new patient passed inclusion criteria a new envelope was opened and } \\
\text { the group was revealed." }\end{array}$ \\
\hline
\end{tabular}

\begin{tabular}{|c|c|c|}
\hline $\begin{array}{l}\text { Blinding of participants } \\
\text { and personnel (perfor- } \\
\text { mance bias) } \\
\text { All outcomes }\end{array}$ & Unclear risk & $\begin{array}{l}\text { "The patients were also masked about their groups; however, since intravitre- } \\
\text { al triamcinolone might cause floaters, we did not consider this study as a dou- } \\
\text { ble-blind one" }\end{array}$ \\
\hline
\end{tabular}

\begin{tabular}{|c|c|c|}
\hline $\begin{array}{l}\text { Blinding of outcome as- } \\
\text { sessment (detection bias) } \\
\text { All outcomes }\end{array}$ & Low risk & $\begin{array}{l}\text { "At baseline and at each study visit thereafter, refraction and BCVA were de- } \\
\text { termined, and OCT was performed by certified examiners masked both to the } \\
\text { randomization and to the findings of previous measurements" }\end{array}$ \\
\hline
\end{tabular}

\begin{tabular}{ll}
\hline $\begin{array}{l}\text { Incomplete outcome data } \\
\text { (attrition bias) }\end{array}$ & Low risk \\
All outcomes & low-up.
\end{tabular}

\begin{tabular}{lll}
\hline $\begin{array}{l}\text { Selective reporting (re- } \\
\text { porting bias) }\end{array}$ & Low risk & All outcomes specified on ClinicalTrials.gov reported \\
\hline Other bias & Unclear risk & None \\
\hline
\end{tabular}

\section{Study characteristics}

Methods Study design: randomised controlled trial

Eyes: 1 eye per participant with bilateral cases excluded

Participants

Country: 56 locations in USA, Canada and Japan

Number of people randomised: 183 (183 eyes)

Number (\%) of people followed-up: 150 (150 eyes) (82.0\%)

Average age: 65.5 years (range unknown) (minimum age 18)

Sex: $45.8 \%$

\section{Inclusion criteria}

- "Adults $\geq 18$ years of age

- Foveal centre-involved macular edema (ME) secondary to BRVO diagnosed within 12 months before the screening visit

- ETDRS BCVA: letter score of 73 to 24 (20/40 to 20/320)"

\section{Exclusion criteria}

- "Current bilateral manifestation of BRVO 
- Uncontrolled glaucoma defined as $\geq 25 \mathrm{mmHg}$ on optimal medical regimen, or previous filtration surgery in either the study eye or the fellow eye

- Insufficient clearing of macular haemorrhage that would prevent the participant from receiving laser treatment safely on day 1 (participants that meet this criterion may be rescreened once the macular haemorrhage resolves)

- Uncontrolled diabetes mellitus (DM)

- Previous use of intraocular corticosteroids or anti-angiogenic drugs in the study eye

- Use of periocular corticosteroids in the study eye within 3 months before day 1

- Use of intraocular or periocular corticosteroids or anti-angiogenic drugs in the fellow eye within 3 months before day 1

- Previous administration of systemic anti-angiogenic medications

- Panretinal scatter photocoagulation, sector laser photocoagulation, or macular grid photocoagulation in the study eye"

- Aflibercept $(n=91)$

\section{Comparator}

- $\operatorname{Laser}(\mathrm{n}=92)$

\section{Treatment regimen}

- Eyes in the IAI group $(n=91)$ received $2 \mathrm{mg} I \mathrm{Al}$ every 4 weeks from baseline to week 20 . A sham laser treatment was also performed at baseline. After this, eyes received $2 \mathrm{mg}$ IAl every 8 weeks with rescue laser at week 36 if needed.

- Eyes in the laser group $(n=92)$ received macular laser photocoagulation at baseline and sham injections every 4 weeks from baseline to week 20. After this, eyes received 3 of $2 \mathrm{mg}$ IAl every 4 weeks then 8 -weekly with rescue laser at week 36 if needed.

\section{Co-intervention: none}

Sample size calculation: Based on prior studies with anti-VEGF and laser, the proportion of eyes gaining 3 lines was estimated to be 55\% for the IAI group and 30\% for the laser group. Hence, a sample size of 81 eyes per group was required to ensure $90 \%$ power at a 2 -sided $5 \%$ significance level. Assuming a $10 \%$ dropout rate, 90 eyes were needed per treatment group.

\section{Outcomes}

\section{Primary outcome}

"Participants Who Gained at Least 15 Letters in Best Corrected Visual Acuity (BCVA) at Week 24"

\section{Secondary outcome}

- Change from baseline to week 24 in BCVA score

- Change from baseline in central retinal thickness (CRT) at week 24

- Change from baseline in the National Eye Institute Visual Function Questionnaire - 25 (NEI VFQ-25) Questionnaire total score at week 24

Follow-up: 12 months 
VIBRANT (Continued)

\begin{tabular}{|c|c|c|}
\hline Bias & Authors' judgement & Support for judgement \\
\hline $\begin{array}{l}\text { Random sequence genera- } \\
\text { tion (selection bias) }\end{array}$ & Low risk & $\begin{array}{l}\text { "Eyes were randomized 1:1 into the IAI and laser groups according to a prede- } \\
\text { termined central randomization scheme" }\end{array}$ \\
\hline $\begin{array}{l}\text { Allocation concealment } \\
\text { (selection bias) }\end{array}$ & Low risk & $\begin{array}{l}\text { "Randomisation provided by an interactive voice/web response system to the } \\
\text { designated unmasked personnel." }\end{array}$ \\
\hline $\begin{array}{l}\text { Blinding of participants } \\
\text { and personnel (perfor- } \\
\text { mance bias) }\end{array}$ & Low risk & $\begin{array}{l}\text { Masking of participants and investigators. A sham laser treatment was also } \\
\text { performed at baseline. Eyes in the laser group received macular laser photoco- } \\
\text { agulation at baseline and sham injections every } 4 \text { weeks from baseline to week }\end{array}$ \\
\hline All outcomes & & 20 \\
\hline
\end{tabular}

\begin{tabular}{|c|c|c|}
\hline $\begin{array}{l}\text { Blinding of outcome as- } \\
\text { sessment (detection bias) } \\
\text { All outcomes }\end{array}$ & Low risk & $\begin{array}{l}\text { Optical coherence tomography images were evaluated by an independent } \\
\text { central reading centre }\end{array}$ \\
\hline
\end{tabular}

\begin{tabular}{|c|c|c|}
\hline $\begin{array}{l}\text { Incomplete outcome data } \\
\text { (attrition bias) } \\
\text { All outcomes }\end{array}$ & Low risk & $\begin{array}{l}\text { All randomised eyes in both treatment groups were included in the full analy- } \\
\text { sis set, except for } 2 \text { eyes in the laser group that did not have a post-baseline } \\
\text { BCVA assessment. }\end{array}$ \\
\hline $\begin{array}{l}\text { Selective reporting (re- } \\
\text { porting bias) }\end{array}$ & Low risk & All outcomes reported as stated \\
\hline Other bias & Unclear risk & None \\
\hline
\end{tabular}

AMD: age-related macular degeneration; anti-VEGF: anti-vascular endothelial growth factor; BCVA: best-corrected visual acuity; BRVO: branch retinal vein occlusion; CMT: central macular thickness; CVA: cerebrovascular accident; ETDRS: Early Treatment Diabetic Retinopathy Study; GLP: grid laser photocoagulation; HRVO: hemi-retinal vein occlusion; MI: myocardial infarction; MO: macular oedema; NEI VFQ-25: National Eye Institute Visual Functioning Questionnaire-25; OCT: optical coherence tomography; RVO: retinal vein occlusion

Characteristics of excluded studies [ordered by study ID]

\begin{tabular}{ll}
\hline Study & Reason for exclusion \\
\hline BRAVO 2010 & Combination treatment \\
\hline Campochiaro 2008 & Dose-finding study \\
\hline Campochiaro 2010a & Dose-finding study \\
\hline Chiquet 2015 & Retrospective study; not randomised \\
\hline Chiquet 2016 & Combination treatment; not randomised \\
\hline COMRADE Extension 2018 & Non-randomised participant selection at end of 6-month COMRADE-B study \\
\hline CRAVE 2015 & Anti-VEGF vs anti-VEGF protocol \\
\hline Donati 2012 & Combination treatment study \\
\hline Gu 2017 & CRVO and BRVO; not randomised \\
\hline Guignier 2013 & Not randomised \\
\hline
\end{tabular}




\begin{tabular}{|c|c|}
\hline Study & Reason for exclusion \\
\hline Hanhart 2017 & Combination treatment; not treatment naive \\
\hline Kartasasmita 2016 & Combination therapy \\
\hline Klimes 2015 & Anti-VEGF vs anti-VEGF protocol \\
\hline Leitritz 2013 & Not randomised \\
\hline Liu 2014 & Anti-VEGF used against label guidelines (only 1 injection in 6 month study) \\
\hline MARVEL & Anti-VEGF vs anti-VEGF protocol \\
\hline Moon 2016 & Combination therapy \\
\hline Moradian 2011 & Follow-up period less than 6 months \\
\hline Ramezani 2014 & CRVO not BRVO \\
\hline Regnier 2015 & Review article \\
\hline Russo 2009 & Quasi-RCT \\
\hline SHORE 2014 & Anti-VEGF v Anti-VEGF protocol \\
\hline Tan 2014 & Combination treatment \\
\hline Tomomatsu 2016 & Combination treatment \\
\hline Wroblewski 2010 & Dose-finding study \\
\hline Zhang 2014 & Combination treatment \\
\hline
\end{tabular}

Characteristics of ongoing studies [ordered by study ID]

\section{NCT01189526}

\begin{tabular}{ll}
\hline Study name & $\begin{array}{l}\text { Comparison of intravitreal ranibizumab and macular laser photocoagulation for macular edema } \\
\text { following branch retinal vein occlusion (BRVO) }\end{array}$ \\
\hline Methods & Randomised. Double-masked \\
\hline Participants & 60 \\
\hline Interventions & Intravitreal ranibizumab 0.5mg injection vs. macular laser photocoagulation
\end{tabular}

\section{Outcomes}

\section{Primary outcome}

- Change in BCVA (ETDRS letters) at 48 weeks

\section{Secondary outcome}

- Change in CRT at 48 weeks

Starting date January 2009


NCT01189526 (Continued)

Contact information ClinicalTrials.gov/ct2/show/NCT01189526

Notes $\quad$ Estimated completion date August 2011.

\section{NCT01795209}

Study name

Ranibizumab for macular edema secondary to branch retinal vein occlusion in patients with fair vision

\begin{tabular}{|c|c|}
\hline Methods & Randomised. Single-masked (participant) \\
\hline Participants & 19 \\
\hline Interventions & Ranibizumab v sham. Rescue laser available in both groups. \\
\hline Outcomes & $\begin{array}{l}\text { Outcome measures } \\
\text { - Time to achieve an improvement of } 10 \text { or more Early Treatment Diabetic Retinopathy Study (ET- } \\
\text { DRS) letters in BCVA } \\
\text { - Mean change from baseline ETDRS letter score over time } \\
\text { - Percentage of participants gaining } 10 \text { or more letters in ETDRS letter score from baseline BCVA } \\
\text { - Percentage of participants gaining < } 10 \text { letters in ETDRS letter score from baseline BCVA } \\
\text { - Percentage of participants losing < } 10 \text { letters in ETDRS letter score from baseline BCVA } \\
\text { - Proportion of participants who at least maintain baseline BCVA } \\
\text { - Percentage of participants with CFT of }<300 \mu m \\
\text { - Safety outcomes } \\
\text { - Mean change from baseline CFT over time } \\
\text { - Mean change from baseline in National Eye Institute Visual Function Questionnaire-25 (NEI- } \\
\text { - MFQ-25) distance activities subscale score } \\
\text { - Mean change from baseline in contrast sensitivity } \\
\text { - Percentage of participants losing } 10 \text { or more letters in ETDRS letter score from baseline BCVA }\end{array}$ \\
\hline Starting date & January 2013 \\
\hline Contact information & URL: ClinicalTrials.gov/show/NCT01795209 \\
\hline
\end{tabular}

Notes

\section{NCT03108352}

$\begin{array}{ll}\text { Study name } & \begin{array}{l}\text { Conbercept ophthalmic injection for patients with macular edema caused by branch retinal vein } \\ \text { occlusion }\end{array}\end{array}$
occlusion

\begin{tabular}{ll}
\hline Methods & Randomised controlled trial. Triple masking \\
\hline Participants & 252 BRVO with MO \\
\hline Interventions & Conbercept ophthalmic injection or sham injection \\
\hline Outcomes & BCVA
\end{tabular}


NCT03108352 (Continued)

\section{CRT}

Number of participants with treatment-related systemic and ocular adverse events

\begin{tabular}{ll}
\hline Starting date & May 2016 \\
\hline Contact information & ClinicalTrials.gov/show/NCT03108352 \\
\hline Notes & $\begin{array}{l}\text { Locations: Beijing Friendship Hospital, Capital Medical University, Beijing, China; Peking Universi- } \\
\text { ty People's Hospital, Beijing, China; Beijing Tongren Hospital, Capital Medical University, Beijing, } \\
\text { China; Zhongshan Hospital, Shanghai, China; Tianjin Medical University Eye Hospital, Tianjing, Chi- } \\
\text { na; Eyes Hospital of Wenzhou Medical University, Wenzhou, China; First Affiliated Hospital of Xi'an } \\
\text { Jiaotong University, Xi'an, China }\end{array}$ \\
\hline
\end{tabular}

BCVA: best-corrected visual acuity; BRVO: branch retinal vein occlusion; CFT: central foveal thickness; CRT: central retinal thickness; EDTRS: Early Treatment Diabetic Retinopathy Study; MO: macular oedema; NEI VFQ-25: National Eye Institute Visual Functioning Questionnaire-25; OCT: optical coherence tomography; VA: visual acuity

\section{DATA AND ANALYSES}

\section{Comparison 1. Anti-VEGF v sham}

\begin{tabular}{lllll}
\hline Outcome or subgroup title & $\begin{array}{l}\text { No. of } \\
\text { studies }\end{array}$ & $\begin{array}{l}\text { No. of } \\
\text { partici- } \\
\text { pants }\end{array}$ & Statistical method & Effect size \\
\hline $\begin{array}{l}1.1 \text { Gain of } 15 \text { letters or more at } 6 \\
\text { months }\end{array}$ & 1 & Risk Ratio (M-H, Fixed, 95\% Cl) & Totals not selected \\
\hline 1.2 Mean VA change at 6 months & 1 & Mean Difference (IV, Fixed, 95\% Cl) & Totals not selected \\
\hline $\begin{array}{l}1.3 \text { Loss of } 15 \text { letters or more at } 6 \\
\text { months }\end{array}$ & 1 & Risk Ratio (M-H, Fixed, 95\% Cl) & Totals not selected \\
\hline 1.4 Mean CRT change at 6 months & 1 & Mean Difference (IV, Fixed, 95\% Cl) & Totals not selected \\
\hline 1.5 Cataract & 1 & Risk Ratio (M-H, Fixed, 95\% Cl) & Totals not selected \\
\hline 1.6 Raised IOP & 1 & Risk Ratio (M-H, Fixed, 95\% Cl) & Totals not selected \\
\hline 1.7 APTC events & 1 & Risk Ratio (M-H, Fixed, 95\% Cl) & Totals not selected \\
\hline 1.8 Quality of life change & 1 & Mean Difference (IV, Fixed, 95\% Cl) & Totals not selected \\
\hline 1.8 .16 months & 1 & Mean Difference (IV, Fixed, 95\% Cl) & Totals not selected \\
\hline 1.8 .212 months & 1 & Mean Difference (IV, Fixed, 95\% Cl) & Totals not selected \\
\hline
\end{tabular}


Analysis 1.1. Comparison 1: Anti-VEGF v sham, Outcome 1: Gain of 15 letters or more at 6 months

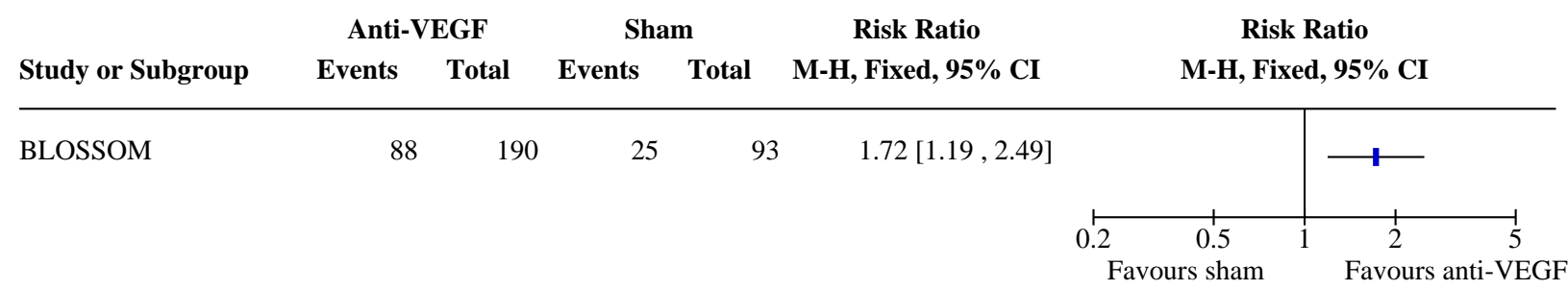

Analysis 1.2. Comparison 1: Anti-VEGF v sham, Outcome 2: Mean VA change at 6 months

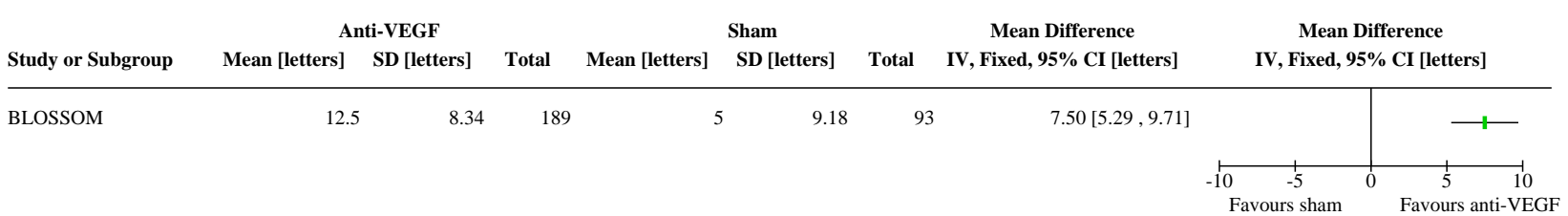

Analysis 1.3. Comparison 1: Anti-VEGF v sham, Outcome 3: Loss of 15 letters or more at 6 months

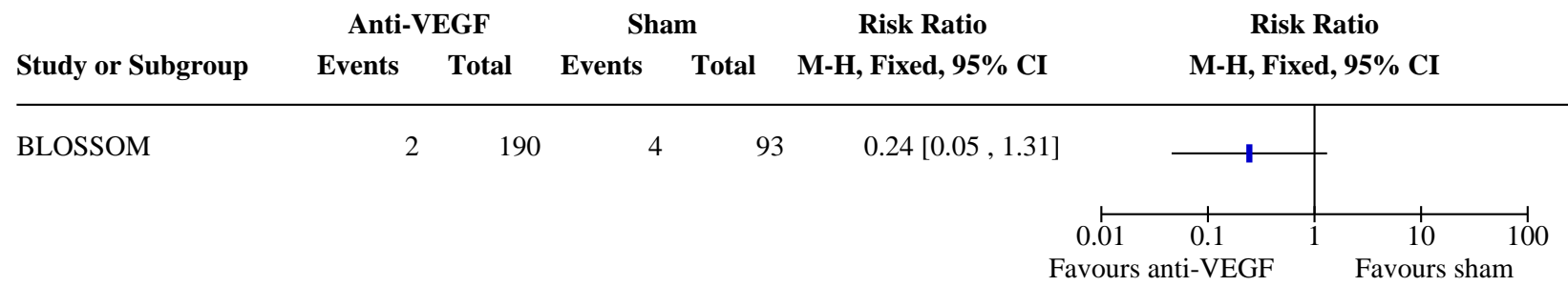

Analysis 1.4. Comparison 1: Anti-VEGF v sham, Outcome 4: Mean CRT change at 6 months

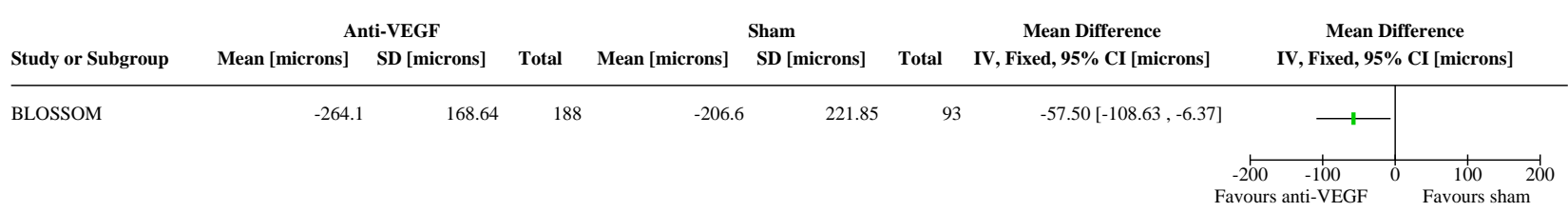

Analysis 1.5. Comparison 1: Anti-VEGF v sham, Outcome 5: Cataract

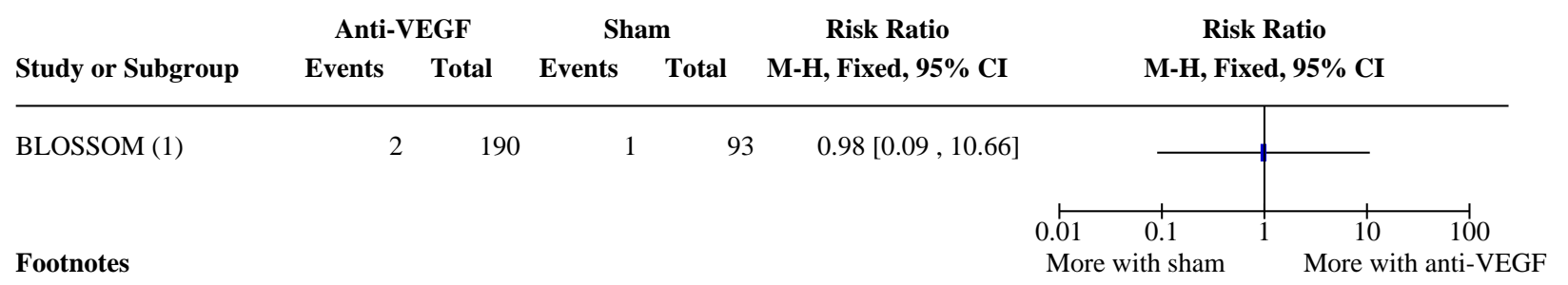

(1) 12 month results. Patients in the sham arm were able to receive rescue anti-VEGF from month 6 . 


\section{Analysis 1.6. Comparison 1: Anti-VEGF v sham, Outcome 6: Raised IOP}

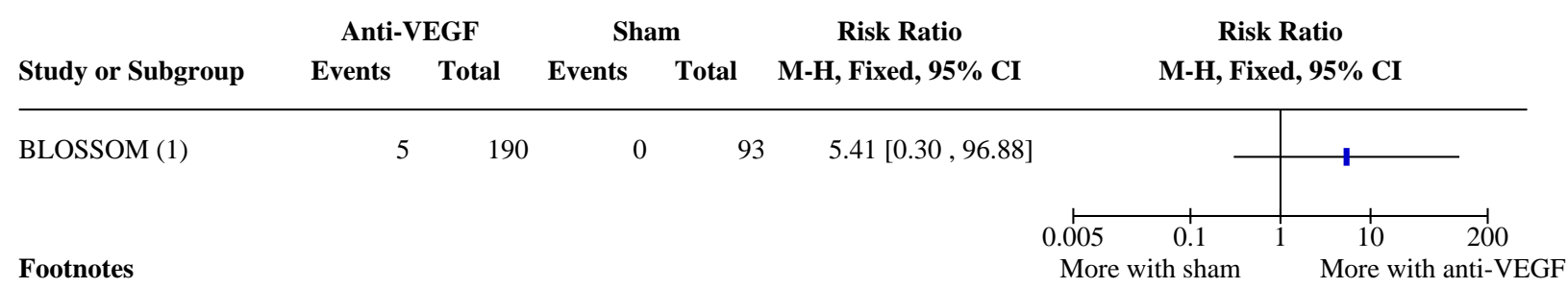

(1) 12 month results. Patients in the sham arm were able to receive rescue anti-VEGF from month 6.

Analysis 1.7. Comparison 1: Anti-VEGF v sham, Outcome 7: APTC events

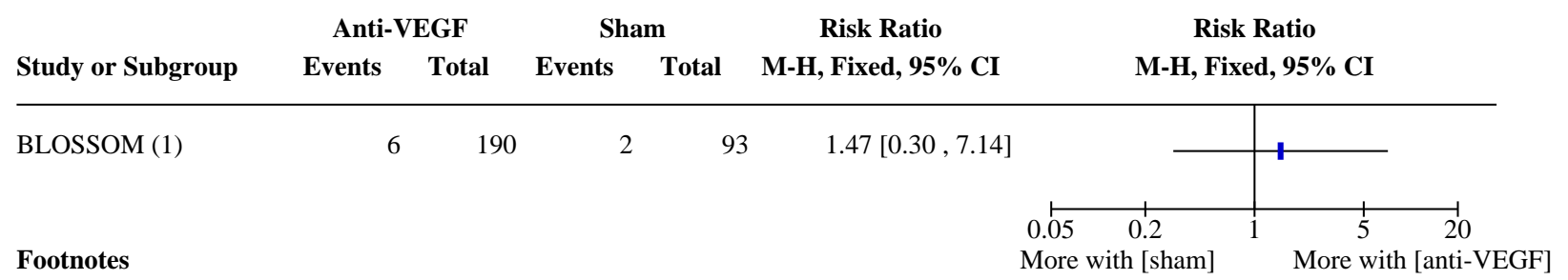

(1) 12 month results. Patients in the sham arm were able to receive rescue anti-VEGF from month 6.

Analysis 1.8. Comparison 1: Anti-VEGF v sham, Outcome 8: Quality of life change

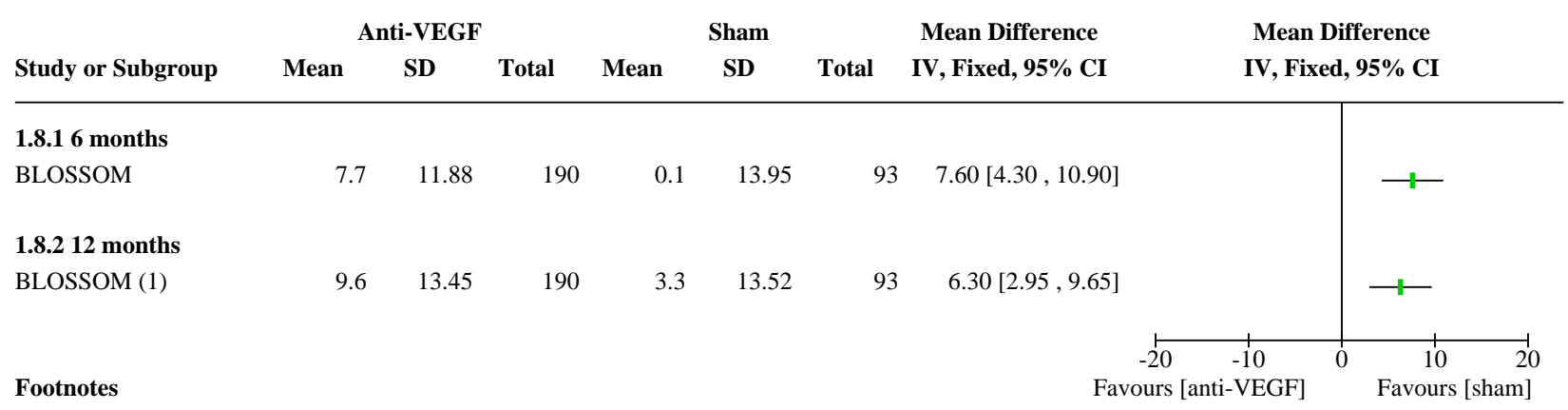

(1) Participants in the sham arm were able to receive rescue anti-VEGF from month 6.

\section{Comparison 2. Anti-VEGF v laser}

\begin{tabular}{llllll}
\hline Outcome or subgroup title & $\begin{array}{l}\text { No. of } \\
\text { studies }\end{array}$ & $\begin{array}{l}\text { No. of } \\
\text { partici- } \\
\text { pants }\end{array}$ & Statistical method & Effect size \\
\hline $\begin{array}{l}2.1 \text { Gain of 15 letters or more at } 6 \\
\text { months }\end{array}$ & 2 & 201 & Risk Ratio (M-H, Fixed, 95\% Cl) & $2.09[1.44,3.05]$ \\
\hline 2.2 Mean VA change at 6 months & 3 & 473 & Mean Difference (IV, Fixed, 95\% Cl) & $9.63[7.23,12.03]$ \\
\hline 2.3 Mean CRT change at 6 months & 2 & 201 & Mean Difference (IV, Fixed, 95\% Cl) & $-147.47[-200.19,-94.75]$ \\
\hline 2.4 Cataract & 2 & & Risk Ratio (M-H, Fixed, 95\% Cl) & Totals not selected \\
\hline 2.5 APTC events & 3 & 476 & Risk Ratio (M-H, Fixed, 95\% Cl) & $0.99[0.15,6.78]$ \\
\hline \hline
\end{tabular}

Anti-vascular endothelial growth factor for macular oedema secondary to branch retinal vein occlusion (Review) 


\section{Analysis 2.1. Comparison 2: Anti-VEGF v laser, Outcome 1: Gain of 15 letters or more at 6 months}

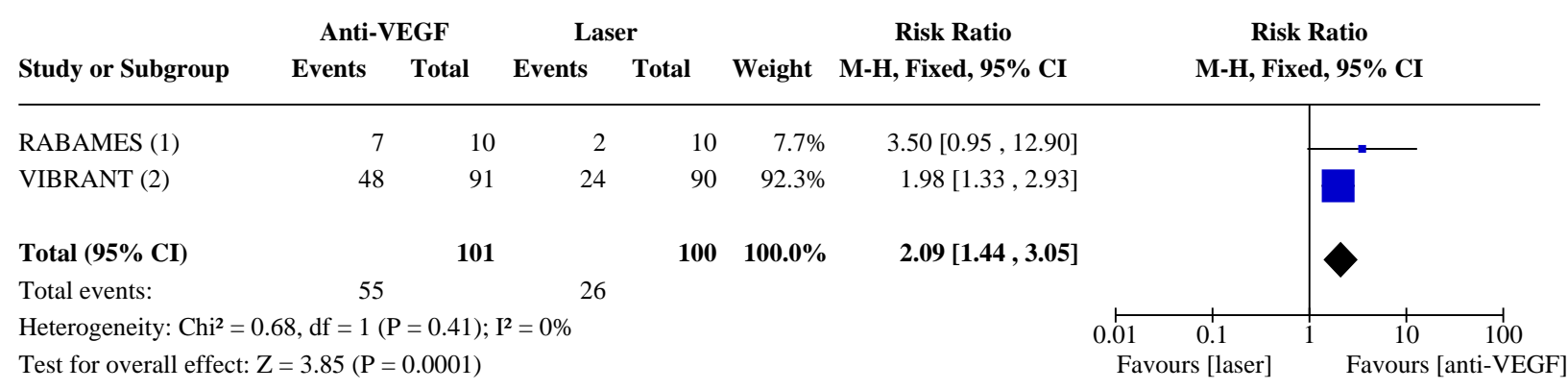

Test for subgroup differences: Not applicable

\section{Footnotes}

(1) RABAMES used ranibizumab $0.5 \mathrm{mg}$

(2) aflibercept

\section{Analysis 2.2. Comparison 2: Anti-VEGF v laser, Outcome 2: Mean VA change at 6 months}

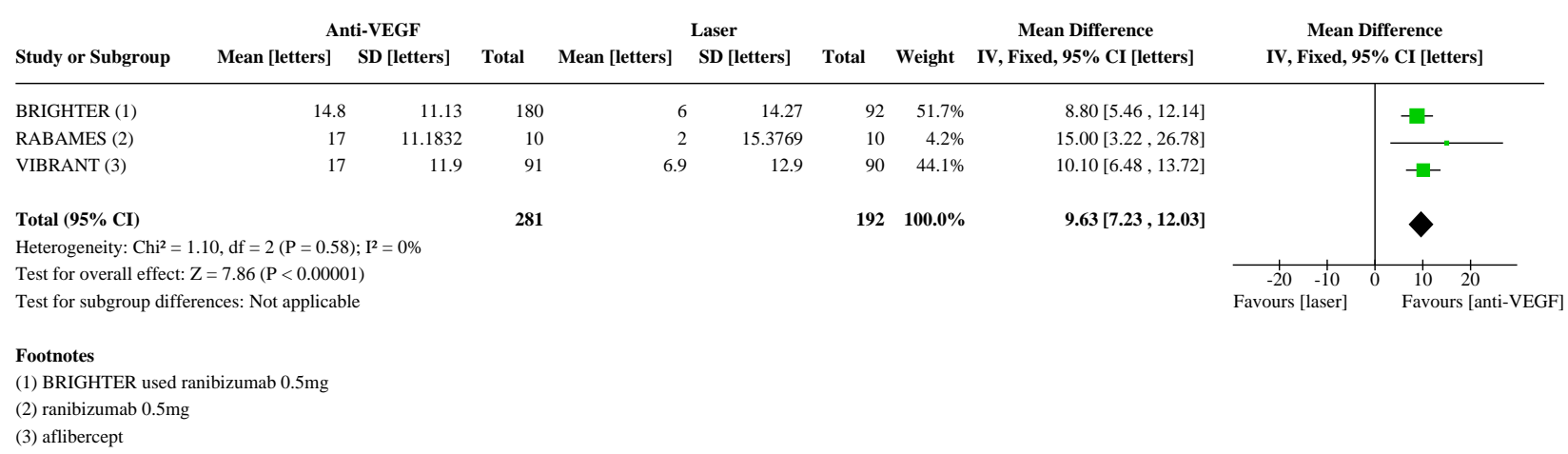

\section{Analysis 2.3. Comparison 2: Anti-VEGF v laser, Outcome 3: Mean CRT change at 6 months}

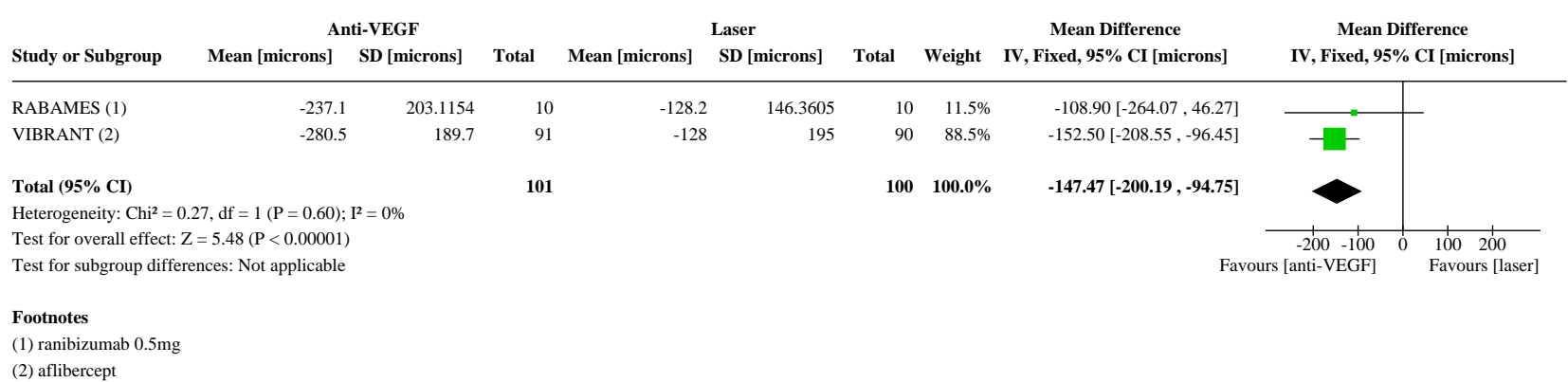




\section{Analysis 2.4. Comparison 2: Anti-VEGF v laser, Outcome 4: Cataract}

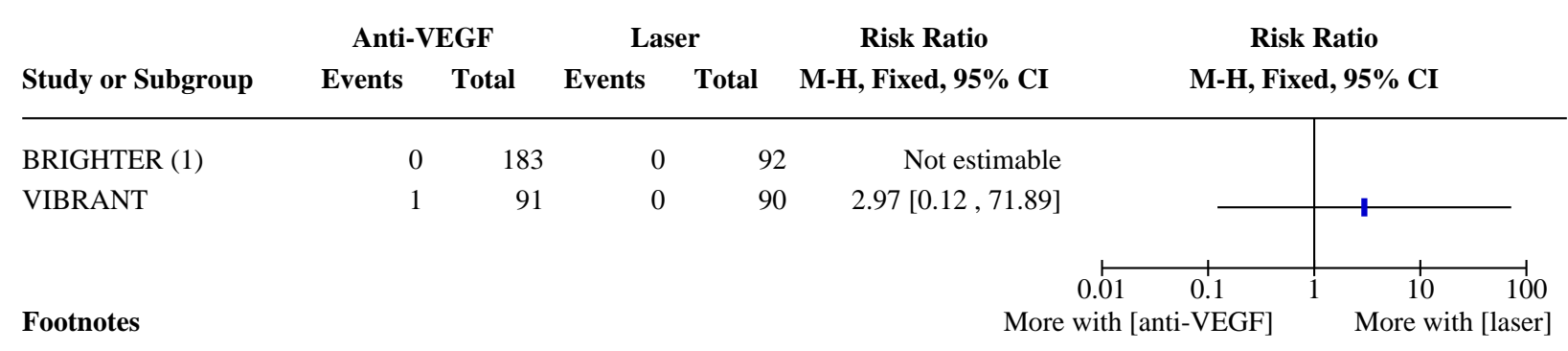

(1) Data for first 6 months only as laser group was able to receive rescue anti-VEGF after this

\section{Analysis 2.5. Comparison 2: Anti-VEGF v laser, Outcome 5: APTC events}

\begin{tabular}{|c|c|c|c|c|c|c|c|}
\hline \multirow[b]{2}{*}{ Study or Subgroup } & \multicolumn{2}{|c|}{ Anti-VEGF } & \multicolumn{2}{|c|}{ Laser } & \multicolumn{2}{|r|}{ Risk Ratio } & \multirow{2}{*}{$\begin{array}{c}\text { Risk Ratio } \\
\text { M-H, Fixed, 95\% CI }\end{array}$} \\
\hline & Events & Total & Events & Total & Weight & M-H, Fixed, 95\% CI & \\
\hline
\end{tabular}

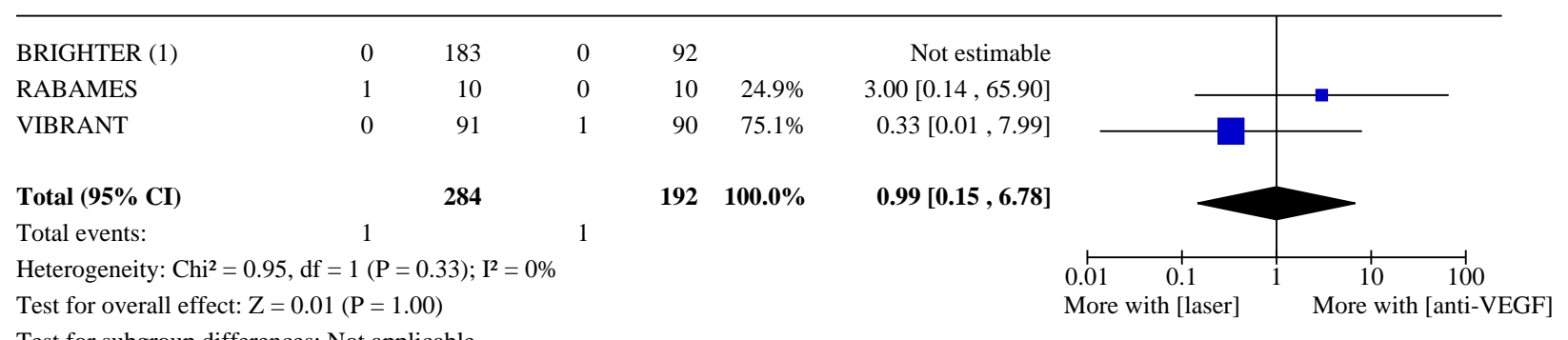

Test for subgroup differences: Not applicable

\section{Footnotes}

(1) Data for first 6 months only as laser group was able to receive rescue anti-VEGF after this

\section{Comparison 3. Anti-VEGF v steroid}

\begin{tabular}{|c|c|c|c|c|}
\hline Outcome or subgroup title & $\begin{array}{l}\text { No. of } \\
\text { studies }\end{array}$ & $\begin{array}{l}\text { No. of } \\
\text { partici- } \\
\text { pants }\end{array}$ & Statistical method & Effect size \\
\hline $\begin{array}{l}3.1 \text { Gain of } 15 \text { letters or more at } 6 \\
\text { months }\end{array}$ & 2 & 330 & Risk Ratio (M-H, Fixed, 95\% Cl) & $1.67[1.33,2.10]$ \\
\hline $\begin{array}{l}3.2 \text { Gain of } 15 \text { letters or more at } 12 \\
\text { months }\end{array}$ & 1 & & Risk Ratio (M-H, Fixed, 95\% Cl) & Totals not selected \\
\hline 3.3 Mean VA change at 6 months & 2 & 330 & Mean Difference (IV, Fixed, 95\% CI) & $8.22[5.69,10.76]$ \\
\hline 3.4 Mean VA change at 12 months & 2 & 343 & Mean Difference (IV, Fixed, 95\% CI) & $9.15[6.32,11.97]$ \\
\hline 3.5 Mean CRT change at 6 months & 2 & 330 & Mean Difference (IV, Fixed, 95\% CI) & $-66.79[-94.69,-38.90]$ \\
\hline 3.6 Mean CRT change at 12 months & 2 & 343 & Mean Difference (IV, Fixed, 95\% CI) & $-26.92[-65.88,12.04]$ \\
\hline 3.7 Quality of life change at 12 months & 1 & & Mean Difference (IV, Fixed, 95\% CI) & Totals not selected \\
\hline 3.8 Cataract & 3 & 637 & Risk Ratio (M-H, Fixed, 95\% Cl) & $0.12[0.04,0.32]$ \\
\hline
\end{tabular}




\begin{tabular}{lllll}
\hline Outcome or subgroup title & $\begin{array}{l}\text { No. of } \\
\text { studies }\end{array}$ & $\begin{array}{l}\text { No. of } \\
\text { partici- } \\
\text { pants }\end{array}$ & Statistical method & Effect size \\
\hline 3.9 Raised IOP & 4 & 673 & Risk Ratio (M-H, Fixed, 95\% Cl) & $0.25[0.16,0.40]$ \\
\hline 3.10 APTC events & 3 & 587 & Risk Ratio (M-H, Fixed, 95\% Cl) & $3.02[0.12,73.55]$ \\
\hline 3.11 Endophthalmitis & 3 & 366 & Risk Ratio (M-H, Fixed, 95\% Cl) & Not estimable \\
\hline
\end{tabular}

\section{Analysis 3.1. Comparison 3: Anti-VEGF v steroid, Outcome 1: Gain of 15 letters or more at 6 months}

\begin{tabular}{|c|c|c|c|c|c|c|c|c|}
\hline \multirow[b]{2}{*}{ Study or Subgroup } & \multicolumn{2}{|c|}{ Anti-VEGF } & \multicolumn{2}{|c|}{ Steroid } & \multirow[b]{2}{*}{ Weight } & \multirow{2}{*}{$\begin{array}{c}\text { Risk Ratio } \\
\text { M-H, Fixed, 95\% CI }\end{array}$} & \multirow{2}{*}{\multicolumn{2}{|c|}{$\begin{array}{c}\text { Risk Ratio } \\
\text { M-H, Fixed, 95\% CI }\end{array}$}} \\
\hline & Events & Total & Events & Total & & & & \\
\hline COMRADE-B (1) & 77 & 126 & 44 & 118 & $72.8 \%$ & $1.64[1.25,2.15]$ & & -1 \\
\hline Ramezani 2012 (2) & 30 & 43 & 17 & 43 & $27.2 \%$ & $1.76[1.16,2.68]$ & & - \\
\hline Total $(95 \% \mathrm{CI})$ & & 169 & & 161 & $100.0 \%$ & $1.67[1.33,2.10]$ & & \\
\hline Total events: & 107 & & 61 & & & & & \\
\hline \multicolumn{7}{|c|}{ Heterogeneity: $\mathrm{Chi}^{2}=0.08, \mathrm{df}=1(\mathrm{P}=0.77) ; \mathrm{I}^{2}=0 \%$} & 0.2 & 2 \\
\hline Test for overall effect & $=4.42(\mathrm{P}<$ & $0.0001)$ & & & & & Favours [steroid] & Favours \\
\hline
\end{tabular}

(1) ranibizumab $0.5 \mathrm{mg}$ v dexamethasone

(2) bevacizumab v triamcinolone

Analysis 3.2. Comparison 3: Anti-VEGF v steroid, Outcome 2: Gain of 15 letters or more at 12 months

\begin{tabular}{|c|c|c|c|c|c|c|}
\hline & Anti & EGF & & & Risk Ratio & Risk Ratio \\
\hline Study or Subgroup & Events & Total & Events & Total & M-H, Fixed, 95\% CI & M-H, Fixed, 95\% CI \\
\hline
\end{tabular}

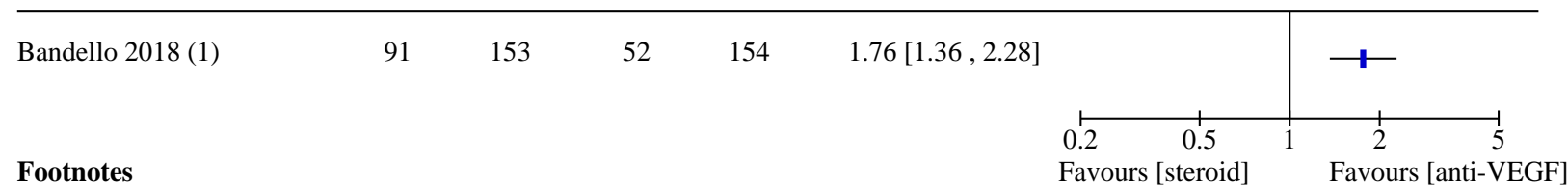

(1) NCT01427751 compared ranibizumab $0.5 \mathrm{mg}$ v dexamethasone

\section{Analysis 3.3. Comparison 3: Anti-VEGF v steroid, Outcome 3: Mean VA change at 6 months}

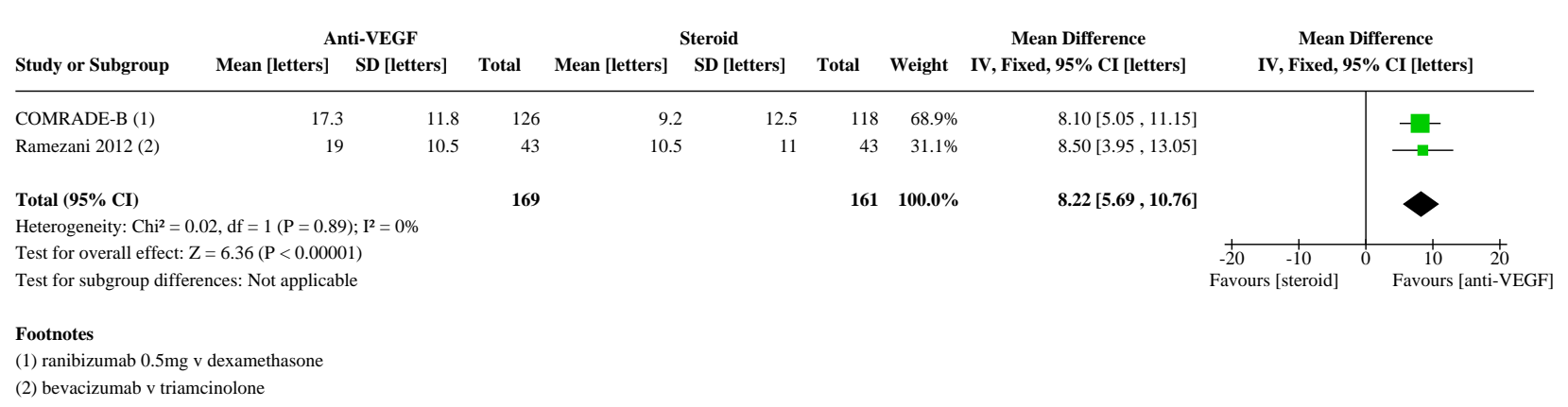




\section{Analysis 3.4. Comparison 3: Anti-VEGF v steroid, Outcome 4: Mean VA change at 12 months}

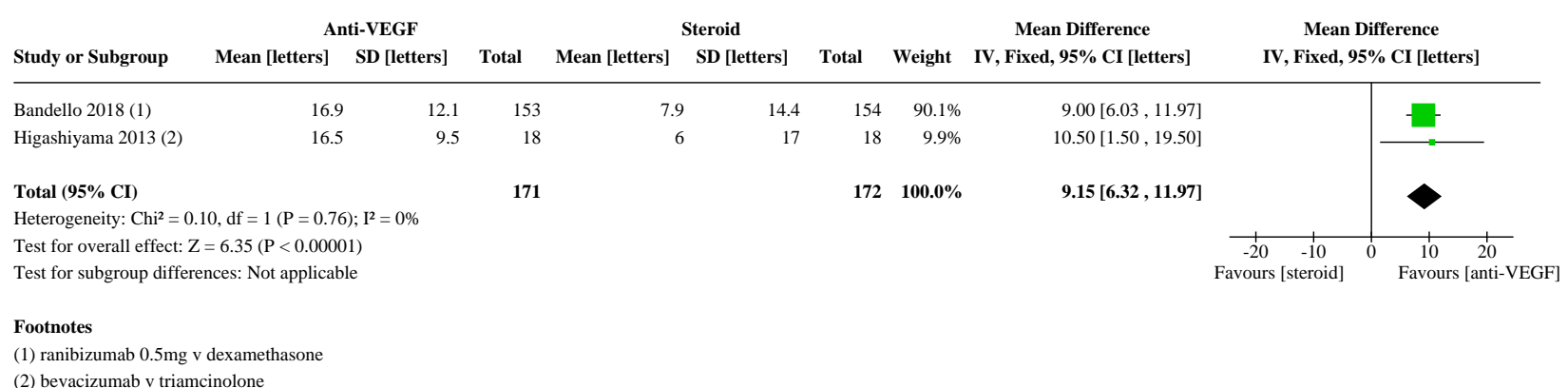

\section{Analysis 3.5. Comparison 3: Anti-VEGF v steroid, Outcome 5: Mean CRT change at 6 months}

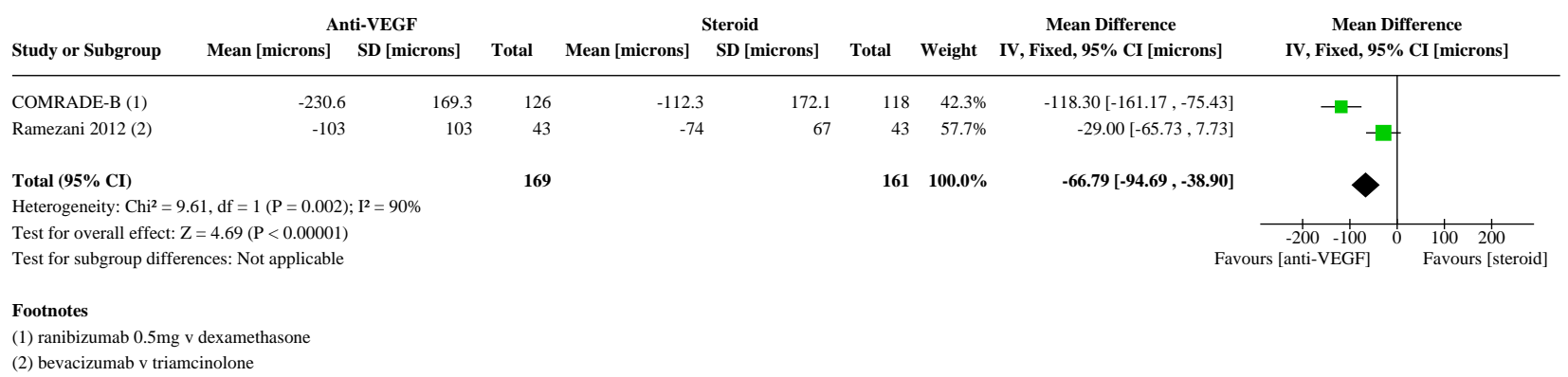

\section{Analysis 3.6. Comparison 3: Anti-VEGF v steroid, Outcome 6: Mean CRT change at 12 months}

\begin{tabular}{|c|c|c|c|c|c|c|c|c|c|c|}
\hline Study or Subgroup & \multicolumn{2}{|c|}{ Anti-VEGF } & \multicolumn{4}{|c|}{ Steroid } & Weight & $\begin{array}{c}\text { Mean Difference } \\
\text { IV, Fixed, 95\% CI [microns] }\end{array}$ & \multicolumn{2}{|c|}{$\begin{array}{c}\text { Mean Difference } \\
\text { IV, Fixed, 95\% CI [microns] }\end{array}$} \\
\hline Bandello 2018 (1) & -253.5 & 197.1 & 153 & -219.2 & 180.5 & 154 & $84.9 \%$ & $-34.30[-76.59,7.99]$ & & \\
\hline Higashiyama 2013 (2) & -270 & 100 & 8 & -304 & 137 & 9 & $11.8 \%$ & $34.00[-79.19,147.19]$ & & \\
\hline Higashiyama 2013 (3) & -362 & 281 & 10 & -306 & 194 & 9 & $3.3 \%$ & $-56.00[-271.40,159.40]$ & & \\
\hline $\begin{array}{l}\text { Total }(\mathbf{9 5} \% \mathbf{C I}) \\
\text { Heterogeneity: } \mathrm{Chi}^{2}=1 .\end{array}$ & $30, \mathrm{df}=2(\mathrm{P}=0.52)$ & $I^{2}=0 \%$ & 171 & & & 172 & $100.0 \%$ & $-26.92[-65.88,12.04]$ & & \\
\hline $\begin{array}{l}\text { Test for overall effect: } Z \\
\text { Test for subgroup differe }\end{array}$ & $\begin{array}{l}=1.35(\mathrm{P}=0.18) \\
\text { nces: Not applicable }\end{array}$ & & & & & & & Fav & 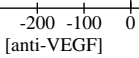 & $\begin{array}{cc}100 & 200 \\
\text { Favours [steroid] }\end{array}$ \\
\hline $\begin{array}{l}\text { Footnotes } \\
\text { (1) ranibizumab } 0.5 \mathrm{mg} v \\
\text { (2) Participants examine } \\
\text { (3) Participants examine }\end{array}$ & $\begin{array}{l}\text { dexamethasone } \\
\text { d with Stratus OCT }(b \\
\text { d with Cirrus OCT (b }\end{array}$ & $\begin{array}{l}\text { bevacizumab v tria } \\
\text { evacizumab v trial }\end{array}$ & $\begin{array}{l}\text { mcinolone) } \\
\text { ncinolone) }\end{array}$ & & & & & & & \\
\hline
\end{tabular}

\section{Analysis 3.7. Comparison 3: Anti-VEGF v steroid, Outcome 7: Quality of life change at 12 months}

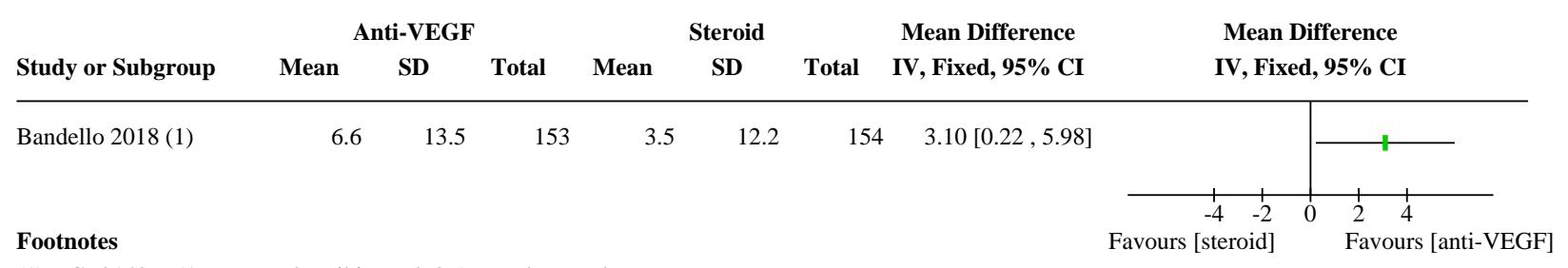

(1) NCT01427751 compared ranibizumab $0.5 \mathrm{mg}$ v dexamethasone 
Analysis 3.8. Comparison 3: Anti-VEGF v steroid, Outcome 8: Cataract

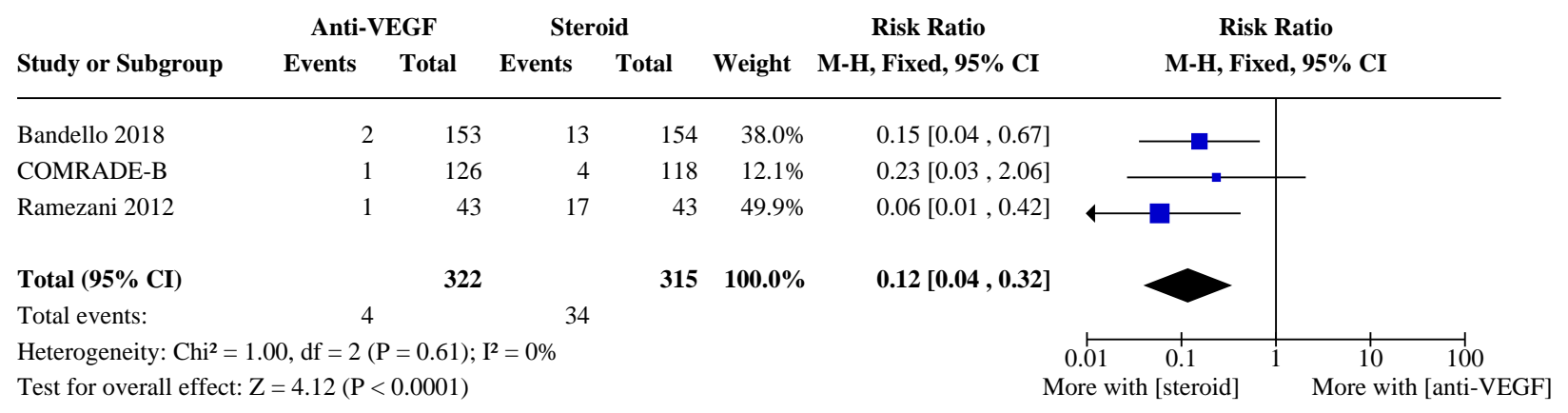

Test for subgroup differences: Not applicable

\section{Analysis 3.9. Comparison 3: Anti-VEGF v steroid, Outcome 9: Raised IOP}

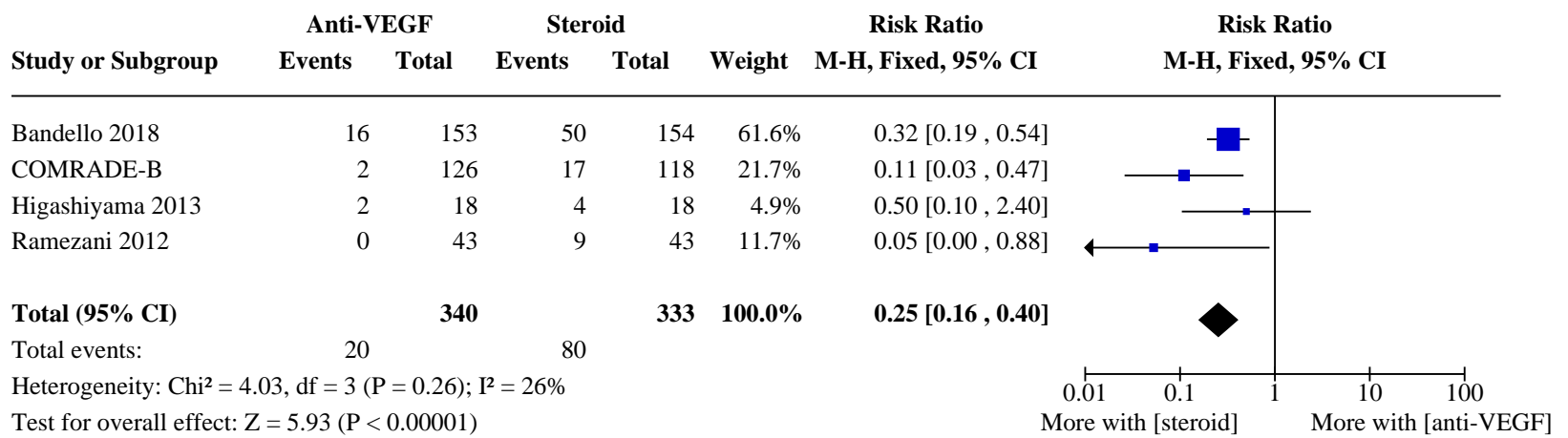

Test for subgroup differences: Not applicable

Analysis 3.10. Comparison 3: Anti-VEGF v steroid, Outcome 10: APTC events

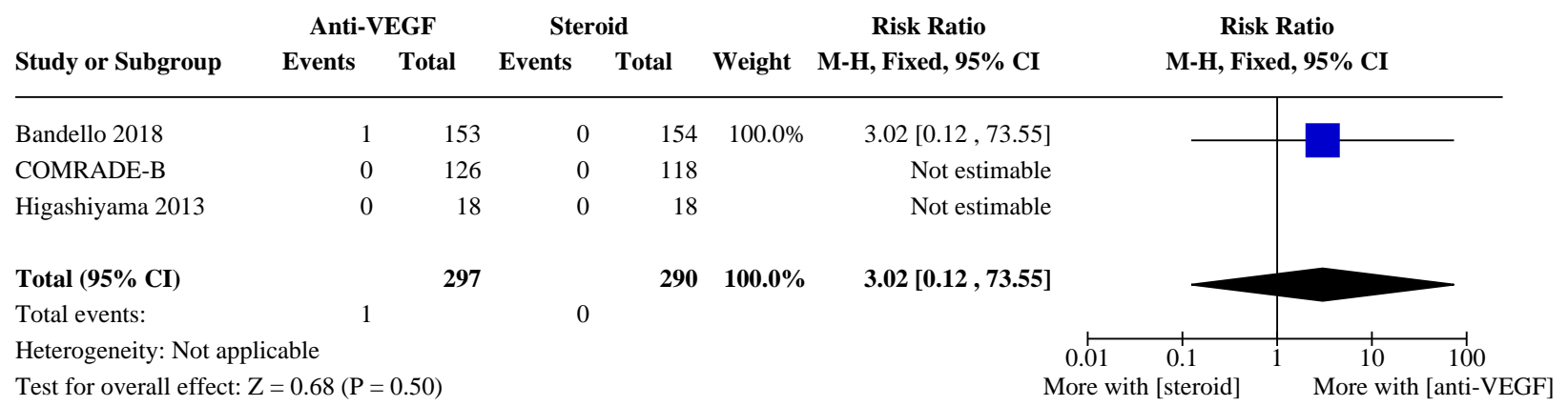


Analysis 3.11. Comparison 3: Anti-VEGF v steroid, Outcome 11: Endophthalmitis

\begin{tabular}{|c|c|c|c|c|c|c|c|}
\hline \multirow[b]{2}{*}{ Study or Subgroup } & \multicolumn{2}{|c|}{ Anti-VEGF } & \multicolumn{2}{|c|}{ Steroid } & \multirow[b]{2}{*}{ Weight } & \multirow{2}{*}{$\begin{array}{c}\text { Risk Ratio } \\
\text { M-H, Fixed, 95\% CI }\end{array}$} & \multirow{2}{*}{$\begin{array}{c}\text { Risk Ratio } \\
\text { M-H, Fixed, 95\% CI }\end{array}$} \\
\hline & Events & Total & Events & Total & & & \\
\hline COMRADE-B & 0 & 126 & 0 & 118 & & Not estimable & \\
\hline Higashiyama 2013 & 0 & 18 & 0 & 18 & & Not estimable & \\
\hline Ramezani 2012 & 0 & 43 & 0 & 43 & & Not estimable & \\
\hline Total $(95 \%$ CI $)$ & & 187 & & 179 & & Not estimable & \\
\hline Total events: & 0 & & 0 & & & & \\
\hline Heterogeneity: Not ap & cable & & & & & 0.01 & 0.1 \\
\hline
\end{tabular}

Test for overall effect: Not applicable

Test for subgroup differences: Not applicable

\section{ADDITIONAL TABLES}

\section{Table 1. Interventional case studies}

\begin{tabular}{|c|c|c|c|c|c|c|}
\hline $\begin{array}{l}\text { Study } \\
\text { name }\end{array}$ & $\begin{array}{l}\text { Number of } \\
\text { eyes includ- } \\
\text { ed }\end{array}$ & $\begin{array}{l}\text { Prospec- } \\
\text { tive } \\
\text { re- } \\
\text { cruit- } \\
\text { ment }\end{array}$ & $\begin{array}{l}\text { Drug and } \\
\text { dose }\end{array}$ & $\begin{array}{l}\text { Mean } \\
\text { IVI }\end{array}$ & $\begin{array}{l}\text { Mean } \\
\text { f-up }\end{array}$ & Outcome \\
\hline $\begin{array}{l}\text { Abegg } \\
2008\end{array}$ & 32 eyes & No & $\begin{array}{l}\text { Beva- } \\
\text { cizumab } \\
1.25 \mathrm{mg}\end{array}$ & 1.7 & $\begin{array}{l}4 \mathrm{~m} \\
\text { (me- } \\
\text { dian) }\end{array}$ & $\begin{array}{l}\text { Mean BCVA (logMAR) improved from } 0.7 \text { to } 0.5 \text { and mean CMT im- } \\
\text { proved from } 454 \mu \mathrm{m} \text { to } 305 \mu \mathrm{m}\end{array}$ \\
\hline $\begin{array}{l}\text { Ah- } \\
\text { madi } \\
2009\end{array}$ & $\begin{array}{l}42 \text { eyes } \\
\text { (All non-is- } \\
\text { chaemic) }\end{array}$ & No & $\begin{array}{l}\text { Beva- } \\
\text { cizumab } \\
1.25 \mathrm{mg}\end{array}$ & & $12 \mathrm{~m}$ & $\begin{array}{l}\text { Improvement in mean Snellen BCVA from } 20 / 280 \text { to } 20 / 170 \text { at final } \\
\text { follow-up. Mean CMT reduction from } 451 \mu \mathrm{m} \text { to } 400 \mu \mathrm{m} \text { at } 6 \text { mths. }\end{array}$ \\
\hline $\begin{array}{l}\text { Byeon } \\
2007\end{array}$ & $\begin{array}{l}39 \text { eyes ( } 14 \\
\text { with MO and } \\
\text { BRVO) }\end{array}$ & No & $\begin{array}{l}\text { Beva- } \\
\text { cizumab } \\
1.25 \mathrm{mg}\end{array}$ & 1.4 & $5.4 \mathrm{~m}$ & $\begin{array}{l}50 \% \text { of patients had previous laser treatment. The mean log-MAR } \\
\text { of the BRVO group was } 0.71 \text {, and this improved } 1 \text { month after the } \\
\text { second injection to } 0.34 \text {. The mean CMT was } 468.6 \mu \mathrm{m} \text { which de- } \\
\text { creased to } 186.4 \mu \mathrm{m} \text { at final follow-up. No significant ocular or sys- } \\
\text { temic SE. }\end{array}$ \\
\hline $\begin{array}{l}\text { Byun } \\
2010\end{array}$ & $\begin{array}{l}191 \text { eyes } \\
\text { Comparative } \\
\text { study: IVB } \\
\text { ( } n=73 \text { ) ver- } \\
\text { sus IVTA ( } \mathrm{n}= \\
118) \\
\text { (non-is- } \\
\text { chaemic = } \\
90 \% \text { ) }\end{array}$ & No & $\begin{array}{l}\text { Beva- } \\
\text { cizumab } \\
1.25 \mathrm{mg}\end{array}$ & 1.9 & $\begin{array}{l}11.1 \\
\mathrm{~m}\end{array}$ & $\begin{array}{l}\text { Mean BCVA (logMAR) improved from } 0.91 \text { to } 0.45 \text { in the IVB group } \\
\text { and mean CMT decreased from } 477 \mu \mathrm{m} \text { to } 218 \mu \mathrm{m} \text {. }\end{array}$ \\
\hline $\begin{array}{l}\text { Cekic } \\
2010\end{array}$ & $\begin{array}{l}52 \text { eyes } \\
\text { Compara- } \\
\text { tive study: } \\
\text { IVTA }(n=17) \text {, }\end{array}$ & Yes & $\begin{array}{l}\text { Beva- } \\
\text { cizumab } \\
1.25 \mathrm{mg}\end{array}$ & 1.6 & $6 \mathrm{~m}$ & $\begin{array}{l}\text { Mean BCVA (logMAR) improved from } 0.92 \text { to } 0.45 \text { in the IVB group. } \\
\text { No significant ocular or systemic SE. }\end{array}$ \\
\hline
\end{tabular}

Anti-vascular endothelial growth factor for macular oedema secondary to branch retinal vein occlusion (Review) 
Table 1. Interventional case studies (Continued)

IVB $(n=14)$,

combined ( $\mathrm{n}$

$=21$ )

(All non-is-

chaemic)

\begin{tabular}{|c|c|c|c|c|c|c|}
\hline $\begin{array}{l}\text { Chen } \\
2010\end{array}$ & $\begin{array}{l}83 \text { eyes } \\
\text { Comparative } \\
\text { study: IVTA } \\
(n=25), \text { IVB } \\
(n=24), \text { no } \\
\text { treatment ( } n \\
=34) \\
(56 \% \text { is- } \\
\text { chaemic) }\end{array}$ & Yes & $\begin{array}{l}\text { Beva- } \\
\text { cizumab } \\
2.5 \mathrm{mg}\end{array}$ & 1 & $\begin{array}{l}41.4 \\
\text { wks }\end{array}$ & $\begin{array}{l}\text { BCVA (logMAR) improved from } 0.95 \text { to } 0.79 \text { at } 12 \text { weeks } \\
\text { Mean CMT decreased from } 457 \mu \mathrm{m} \text { to } 323 \mu \mathrm{m} 24 \text { weeks after treat- } \\
\text { ment }\end{array}$ \\
\hline $\begin{array}{l}\text { Cheng } \\
2009\end{array}$ & $\begin{array}{l}29 \text { eyes } \\
\text { Comparative } \\
\text { study: IVTA } \\
(n=16) \text {, IVB } \\
(n=13)\end{array}$ & No & $\begin{array}{l}\text { Beva- } \\
\text { cizumab } \\
1.25 \mathrm{mg}\end{array}$ & 1.6 & $7.4 \mathrm{~m}$ & $\begin{array}{l}61.5 \% \text { of IVB group received previous laser treatment. Improve- } \\
\text { ment in mean BCVA (logMAR) from } 0.99 \text { to } 0.35 \text { at final follow-up. } \\
\text { Reduction in mean CMT from } 538 \mu \mathrm{m} \text { to } 222 \mu \mathrm{m} \text { microns. No sig- } \\
\text { nificant ocular or systemic side effects. }\end{array}$ \\
\hline $\begin{array}{l}\text { Chung } \\
2008\end{array}$ & 50 eyes & No & $\begin{array}{l}\text { Beva- } \\
\text { cizumab } \\
1.25 \mathrm{mg}\end{array}$ & 1.94 & $7.9 \mathrm{~m}$ & $\begin{array}{l}56 \% \text { gained } 5 \text { or more ETDRS letters; } 44 \% \text { had less than } 5 \text { ETDRS } \\
\text { letter gain or worse final BCVA. No significant ocular or systemic } \\
\text { side effects. }\end{array}$ \\
\hline
\end{tabular}

\begin{tabular}{|c|c|c|c|c|c|}
\hline $\begin{array}{l}\text { Figueroa } 28 \text { eyes } \\
2010\end{array}$ & Yes & $\begin{array}{l}\text { Beva- } \\
\text { cizumab } \\
1.25 \mathrm{mg}\end{array}$ & 3.7 & $6 \mathrm{~m}$ & $\begin{array}{l}\text { Improvement in mean BCVA (logMAR) from } 0.8 \text { to } 0.44 \text { at final fol- } \\
\text { low-up. Reduction in mean CMT from } 486 \mu \mathrm{m} \text { to } 268 \mu \mathrm{m} \text {. }\end{array}$ \\
\hline
\end{tabular}

\begin{tabular}{|c|c|c|c|c|c|c|}
\hline $\begin{array}{l}\text { Gre- } \\
\text { gori } \\
2009\end{array}$ & $\begin{array}{l}52 \text { eyes } \\
\text { ( } 23 \% \text { is- } \\
\text { chaemic) }\end{array}$ & No & $\begin{array}{l}\text { Beva- } \\
\text { cizumab } \\
1.25 \mathrm{mg}\end{array}$ & 3.3 & $12 \mathrm{~m}$ & $\begin{array}{l}\text { Only } 17 \text { eyes ( } 26 \% \text { ) returned for follow-up. The median Snellen } \\
\text { BCVA improved from } 20 / 100 \text { at baseline to } 20 / 50 \text { at } 12 \text { months. } \\
\text { The mean CMT decreased by } 205 \mu \text { m compared with baseline. }\end{array}$ \\
\hline
\end{tabular}

\begin{tabular}{|c|c|c|c|c|c|c|}
\hline $\begin{array}{l}\text { Gun- } \\
\text { duz } \\
2008\end{array}$ & $\begin{array}{l}12 \text { eyes } \\
\text { ( } 40 \% \text { is- } \\
\text { chaemic) }\end{array}$ & No & $\begin{array}{l}\text { Beva- } \\
\text { cizumab } \\
1.25 \mathrm{mg}\end{array}$ & 4 & $9.8 \mathrm{~m}$ & $\begin{array}{l}\text { Improvement in mean BCVA (logMAR) from } 0.91 \text { to } 0.48 \text { at final fol } \\
\text { low-up. Reduction in mean CMT from } 506 \mu \mathrm{m} \text { to } 267.5 \mu \mathrm{m} \text {. }\end{array}$ \\
\hline $\begin{array}{l}\text { Hara } \\
2010\end{array}$ & 91 eyes & No & $\begin{array}{l}\text { Beva- } \\
\text { cizumab } \\
1.25 \mathrm{mg}\end{array}$ & 1.3 & $\begin{array}{l}\text { Up to } \\
3 \mathrm{~m}\end{array}$ & Mean reduction in CMT from $610 \mu \mathrm{m}$ to $368 \mu \mathrm{m}$ after 1 injection \\
\hline
\end{tabular}

\begin{tabular}{|c|c|c|c|c|c|c|}
\hline $\begin{array}{l}\text { Hoeh } \\
2009\end{array}$ & $\begin{array}{l}61 \text { eyes (34 } \\
\text { with BRVO) }\end{array}$ & Yes & $\begin{array}{l}\text { Beva- } \\
\text { cizumab } \\
2.5 \mathrm{mg}\end{array}$ & 4.9 & $3 \mathrm{~m}$ & $\begin{array}{l}\text { Mean BCVA (logMAR) improved from } 0.50 \text { to } 0.32 \text {. Mean CMT de- } \\
\text { creased from } 602 \mu \mathrm{m} \text { to } 386 \mu \mathrm{m} \text {. }\end{array}$ \\
\hline
\end{tabular}


Table 1. Interventional case studies (Continued)

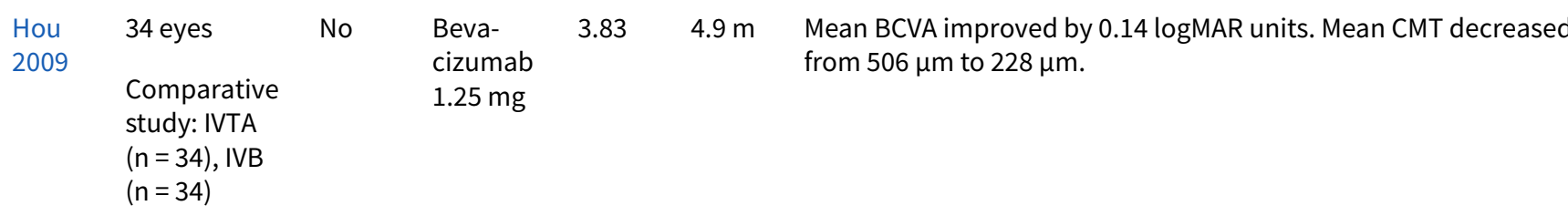

\begin{tabular}{|c|c|c|c|c|c|c|}
\hline $\begin{array}{l}\text { Jaissle } \\
2009\end{array}$ & $\begin{array}{l}23 \\
\text { (All non-is- } \\
\text { chaemic) }\end{array}$ & Yes & $\begin{array}{l}\text { Beva- } \\
\text { cizumab } \\
1.25 \mathrm{mg}\end{array}$ & $\begin{array}{l}1.6 \text { in } \\
\text { first } 6 \\
\text { months } \\
\text { and } \\
0.8 \text { in } \\
\text { sec- } \\
\text { ond } 6 \\
\text { months }\end{array}$ & $12 \mathrm{~m}$ & $\begin{array}{l}\text { The median VA gained } 3.0 \text { lines from baseline at } 48 \text { weeks and } \\
\text { there was a decrease of } 39 \% \text { of the median CMT. }\end{array}$ \\
\hline
\end{tabular}

\begin{tabular}{lllll}
\hline Jaissle 205 eyes & No & $\begin{array}{l}\text { Beva- } \\
\text { cizumab }\end{array}$ & $\begin{array}{l}36.8 \\
\text { wks }\end{array}$ & $\begin{array}{l}\text { The median BCVA (logMAR) was 0.6 at baseline improving to } 0.4 . \\
\text { Reduction in CMT, from a baseline of } 454 \mu \mathrm{m} \text { to } 248 \mu \mathrm{m} .\end{array}$
\end{tabular}

\begin{tabular}{llllll}
\hline $\begin{array}{l}\text { Kon- } \\
\text { do }\end{array}$ & 50 eyes & Yes & $\begin{array}{l}\text { Beva- } \\
\text { cizumab } \\
1.25 \mathrm{mg}\end{array}$ & 2 & $12 \mathrm{~m}$
\end{tabular}$\quad \begin{aligned} & \begin{array}{l}\text { The mean BCVA (logMAR) improved from 0.53 to 0.26. Mean CMT } \\
\text { decreased from } 523 \mu \mathrm{m} \text { to } 305 \mu \mathrm{m} .\end{array} \\
& 2009\end{aligned}$

\begin{tabular}{|c|c|c|c|c|c|}
\hline $\begin{array}{l}\text { Kreutzer } 34 \text { eyes } \\
2008\end{array}$ & Yes & $\begin{array}{l}\text { Beva- } \\
\text { cizumab } \\
1.25 \mathrm{mg}\end{array}$ & 2.9 & $6 \mathrm{~m}$ & $\begin{array}{l}\text { The mean BCVA (logMAR) improved from } 0.79 \text { to } 0.51 \text { at } 6 \text { months. } \\
\text { Mean CMT decreased from } 474 \mu \mathrm{m} \text { to } 316 \mu \mathrm{m} \text {. }\end{array}$ \\
\hline
\end{tabular}

\begin{tabular}{|c|c|c|c|c|c|c|}
\hline $\begin{array}{l}\text { Kriech- } \\
\text { baum } \\
2008\end{array}$ & $\begin{array}{l}29 \text { eyes }(21 \\
\text { with BRVO) }\end{array}$ & Yes & $\begin{array}{l}\text { Beva- } \\
\text { cizumab } \\
1.0 \mathrm{mg}\end{array}$ & 2.3 & $6 \mathrm{~m}$ & $\begin{array}{l}\text { Baseline mean BCVA was } 50 \text { ETDRS letters, by month } 6 \text {, BCVA im- } \\
\text { proved to } 65 \text { letters. CMT decreased from } 558 \mu \mathrm{m} \text { to } 382 \mu \mathrm{m} \text {. }\end{array}$ \\
\hline
\end{tabular}

\begin{tabular}{|c|c|c|c|c|c|c|}
\hline $\begin{array}{l}\text { Mehany } \\
2010\end{array}$ & $\begin{array}{l}18 \text { eyes with } \\
\text { BRVO } \\
\text { (All non-is- } \\
\text { chaemic) }\end{array}$ & No & $\begin{array}{l}\text { Beva- } \\
\text { cizumab } \\
1.25 \mathrm{mg}\end{array}$ & 2.7 & $12 \mathrm{~m}$ & $\begin{array}{l}\text { Baseline BCVA was } 20 / 240 \text { (logMAR } 1.08 \text { ) improving to } 20 / 60 \text { (log- } \\
\text { MAR } 0.48 \text { ) at the end of follow-up (approx } 12 \text { months). The mean } \\
\text { CMT decreased to } 250 \pm 48 \mu \mathrm{m} \text {. }\end{array}$ \\
\hline $\begin{array}{l}\text { Pai } \\
2007\end{array}$ & 12 eyes & No & $\begin{array}{l}\text { Beva- } \\
\text { cizumab } \\
1.25 \mathrm{mg}\end{array}$ & 1 & $\begin{array}{l}12 \\
\text { wks }\end{array}$ & $\begin{array}{l}\text { Mean BCVA (logMAR) was } 1.22 \text { improving to } 0.61 \text {. The mean CMT } \\
\text { was } 672.8 \mu \mathrm{m} \text { at baseline. There was a } 44.6 \% \text { decrease in CMT } \\
\text { from baseline. }\end{array}$ \\
\hline $\begin{array}{l}\text { Pece } \\
2011\end{array}$ & 8 eyes & Yes & $\begin{array}{l}\text { Ranibizum } \\
\text { ab } 0.5 \\
\mathrm{mg}\end{array}$ & 3.6 & $12 \mathrm{~m}$ & $\begin{array}{l}\text { Mean improvement in BCVA (logMAR) from } 0.800 .41 \text {. Mean reduc- } \\
\text { tion of } 275 \mu \mathrm{m} \text { in CMT from baseline. Contrast sensitivity, time and } \\
\text { reading fluency improved significantly in the treated eyes. }\end{array}$ \\
\hline $\begin{array}{l}\text { Prager } \\
2009\end{array}$ & $\begin{array}{l}21 \text { eyes (BR- } \\
\text { VO only) }\end{array}$ & Yes & $\begin{array}{l}\text { Beva- } \\
\text { cizumab } \\
1 \mathrm{mg}\end{array}$ & 8 & $12 \mathrm{~m}$ & $\begin{array}{l}\text { In the BRVO group }(n=18) \text {, visual acuity increased from } 55 \text { let- } \\
\text { ters }(20 / 80) \text { at baseline to } 73 \text { letters }(20 / 32) \text { at month } 12 \text {. CMT de- } \\
\text { creased significantly by } 241 \mu \mathrm{m} \text { after } 12 \text { months of follow-up. }\end{array}$ \\
\hline
\end{tabular}


Table 1. Interventional case studies (Continued)

\begin{tabular}{lllll}
\hline $\begin{array}{l}\text { Rabena } \\
2007\end{array}$ & No eyes & $\begin{array}{l}\text { Beva- } \\
\text { cizumab } \\
1.25 \mathrm{mg}\end{array}$ & $5.3 \mathrm{~m}$ & $\begin{array}{l}\text { Mean BCVA improved from 20/200 to 20/100 at final follow-up. } \\
\text { Mean CMT decreased from } 487 \mu \mathrm{m} \text { to } 332 \mu \mathrm{m} \text { at final follow-up. No } \\
\text { adverse side effects were observed following injections. }\end{array}$
\end{tabular}

\begin{tabular}{|c|c|c|c|c|c|c|}
\hline $\begin{array}{l}\text { Ren- } \\
\text { sch } \\
2009\end{array}$ & 21 eyes & Yes & $\begin{array}{l}\text { Beva- } \\
\text { cizumab } \\
1.5 \mathrm{mg}\end{array}$ & 3 & $6.2 \mathrm{~m}$ & $\begin{array}{l}\text { Mean BCVA (logMAR) improved from } 0.81 \text { to } 0.55 \text { at } 6 \text { months. } \\
\text { Mean CMT decreased from } 492 \mu \mathrm{m} \text { to } 316 \mu \mathrm{m} \text {. }\end{array}$ \\
\hline $\begin{array}{l}\text { Rou- } \\
\text { vas } \\
2010\end{array}$ & 28 eyes & Yes & $\begin{array}{l}\text { Ranibizum } \\
\text { ab } 0.5 \\
\mathrm{mg}\end{array}$ & & $9 \mathrm{~m}$ & $\begin{array}{l}\text { Mean BCVA (logMAR) improved from } 0.74 \text { to } 0.49 \text {. Mean CMT de- } \\
\text { creased from } 349 \mu \mathrm{m} \text { at baseline to } 229 \mu \mathrm{m} \text {. }\end{array}$ \\
\hline $\begin{array}{l}\text { Schaal } \\
2007\end{array}$ & $\begin{array}{l}22 \text { eyes (BR- } \\
\text { VO only) }\end{array}$ & No & $\begin{array}{l}\text { Beva- } \\
\text { cizumab } \\
2.5 \mathrm{mg}\end{array}$ & 2.6 & $\begin{array}{l}23 \\
\text { wks }\end{array}$ & $\begin{array}{l}76.5 \% \text { of those with BRVO had a significant improved visual acuity } \\
\text { (by at least } 3 \text { lines). Mean CMT decreased from } 678 \mu \mathrm{m} \text { to } 236 \mu \mathrm{m} \text {. }\end{array}$ \\
\hline $\begin{array}{l}\text { Stahl } \\
2007\end{array}$ & 9 eyes & Yes & $\begin{array}{l}\text { Beva- } \\
\text { cizumab } \\
1.25 \mathrm{mg}\end{array}$ & 1 & 9 wks & $\begin{array}{l}\text { Mean BCVA (logMAR) improved from } 0.5 \text { to } 0.31 \text { at } 9 \text { weeks. Mean } \\
\text { CMT reduced from } 408 \mu \mathrm{m} \text { to } 309 \mu \mathrm{m} \text {. }\end{array}$ \\
\hline $\begin{array}{l}\text { Hung } \\
2010\end{array}$ & $\begin{array}{l}25 \text { eyes (12 } \\
\text { with BRVO } \\
\text { only) }\end{array}$ & Yes & $\begin{array}{l}\text { Beva- } \\
\text { cizumab } \\
2.5 \mathrm{mg}\end{array}$ & 2 & $6.5 \mathrm{~m}$ & $\begin{array}{l}50 \%(6 / 12) \text { had received previous treatment. Mean BCVA (logMAR) } \\
\text { improved from } 0.94 \text { to } 0.54 \text { at final follow-up. Mean CMT reduced } \\
\text { from } 392 \mu \mathrm{m} \text { to } 234 \mu \mathrm{m} \text {. }\end{array}$ \\
\hline
\end{tabular}

m: months; wks: weeks; BCVA: best-corrected visual acuity; CMT: central macular thickness; IVTA: intravitreal triamcinolone; IVB: intravitreal bevacizumab; IVI: intravitreal injections; f-up: follow-up; VA: visual acuity

\section{Table 2. Excluded studies}

\begin{tabular}{|c|c|c|}
\hline Study & Study details & Conclusion \\
\hline Campochiaro 2010a & $\begin{array}{l}\text { Dose-finding study: patients with CRVO }(n=14) \\
\text { and BRVO }(n=17) \text { were randomised to receive } \\
\text { either } 0.3 \mathrm{mg} \text { ranibizumab or } 0.5 \mathrm{mg} \text { ranibizum- } \\
\text { ab and followed for } 2 \text { years }\end{array}$ & $\begin{array}{l}\text { The } 0.3 \mathrm{mg} \text { and } 0.5 \mathrm{mg} \text { doses had similar results and } \\
\text { when combined showed that } 20 \text { patients with BRVO had } \\
\text { mean and median improvements in BCVA of } 16.1 \text { and } 15 \\
\text { letters. After } 2 \text { years of follow-up, only } 5 \text { of } 17 \text { patients } \\
\text { with BRVO and } 3 \text { of } 14 \text { patients with CRVO were oede- } \\
\text { ma-free with no injections for at least } 1 \text { year. }\end{array}$ \\
\hline
\end{tabular}

Campochiaro 2008 Dose-finding study: patients with CRVO $(n=20)$ and BRVO $(n=20)$ were randomised to receive 3 monthly injections either $0.3 \mathrm{mg}$ ranibizumab or $0.5 \mathrm{mg}$ ranibizumab.
Primary end point at 3 months: improvement of 10 and 18 letters in the BRVO group for the lower and higher doses respectively.

OCT showed that compared to lower dose injections, 0.5 $\mathrm{mg}$ of ranibizumab tended to cause more rapid reductions of central retinal thickening that lasted longer between injections.

Both the DEX and anti-VEGF groups showed similar improvements in visual acuity and central retinal thickness. However, at 3 months, 5 patients (13\%) in the DEX group and $20(31 \%)$ in the anti-VEGF group $(\mathrm{P}<0.001)$ changed treatment due to poor response. group) without previous treatment were included in this multi-centre retrospective study and evaluated at baseline and 1, 3, 6, and 12 months after the onset of treatment. 


\section{Table 2. Excluded studies (Continued)}

Chiquet $2016 \quad$ Combination therapy retrospective study in CRVO and BRVO. 48 patients - 40 in the anti-VEGF DEX sequence (AD group), 8 in the DEX anti-VEGF sequence (DA group) - were included in this multicentre retrospective study and evaluated at baseline, 1, 3, 6 and 12 months after the switch.
VA significantly improved at 1 month in the $A D$ group ( $P$ $=0.03)$ but not in the DA group $(P=0.40)$. CMT decreased significantly in the $A D$ group at 1,6 and 12 months $(P$ $=0.002, P=0.005$ and $P=0.002$, respectively). In the DA group, VA did not change from baseline at any time point, and CMT decreased at 1 month $(P=0.02)$ but not later on.
CRAVE 2015 Participants were randomised 1:1 to receive monthly treatment with bevacizumab or ranibizumab. The primary outcome was change in central foveal thickness at 6 months compared to baseline.

The trial randomised 98 patients to treatment with bevacizumab or ranibizumab. At 6 months, there were no differences in change in central foveal thickness between groups (bevacizumab: mean reduction of 212.6 microns, $95 \% \mathrm{Cl}$ (confidence interval) -288.3 to -137.0 ; ranibizumab: mean reduction of 243.8 microns, $95 \% \mathrm{Cl},-309.6$ to $-178.0 ; P=0.72$, analysis of variance (ANOVA)). Both groups showed similar functional outcomes (bevacizumab: 0.33 logMAR gain, $95 \% \mathrm{Cl},-0.47$ to -0.18 ; ranibizumab: $0.34 \log$ - MAR gain, $95 \% \mathrm{Cl},-0.45$ to $-0.23 ; \mathrm{P}=0.38$, ANOVA).

COMRADE Extension The COMRADE-B study was a 6-month RCT com2018 paring ranibizumab with dexamethasone implant. The extension study followed up a subset of the original study group for a further 6 months.
Patients enrolled in the extension study were limited only to German centres, and in general had better visual acuity outcomes at 6 months than those not enrolled. In the extension 6 months, eyes in the ranibizumab arm could receive ranibizumab as required. Eyes in the dexamethasone arm could receive 1 further dexamethasone implant in the extension 6 month period. 'Mean average change in best-corrected visual acuity (BCVA) was significantly better for ranibizumab than dexamethasone $(P=$ 0.0249).' Also, "elevated intraocular pressure (IOP) was more frequent with dexamethasone than ranibizumab treatment."

Both groups demonstrated a mean improvement in BC VA and CMT at 12 months, however the combination groups required fewer IVB injections; (median of $4 \pm 1.1$ for IVB alone versus $3 \pm 0.4$ in the combination group) ( $P$ $=0.03$ ). ceive either IVB $(n=9)$ at baseline, month 1 and month 2 or $(n=9)$ IVB at baseline, month 1 and month 2 with grid laser photocoagulation after the second injection.

Gu $2017 \quad$ Non-randomised case series in CRVO and BRVO. $32 \mathrm{ME}$ cases treated with Ozurdex and $32 \mathrm{ME}$ cases treated with ranibizumab were enrolled, with 26 central (C)RVO and 6 branch (B)RVO participants in each group. The authors compared the results of best-corrected visual acuity (BCVA), central retinal thickness, number of injections, and intraocular pressure (IOP) at 1, 2, 3, and 6 months after injection.
BCVA in both groups at each follow-up were significantly increased compared to baseline with no statistical difference between the groups. Ozurdex and ranibizumab successfully reduced CMT at each follow-up. Both CRVO and BRVO patients had significant between-group differences in the mean number of injections. Among the CRVO patients, IOP in the Ozurdex group was significantly increased compared to baseline and the ranibizumab group at 1, 2, and 3 months postinjection.

The mean visual acuity was significantly better 1 month after treatment in group 2, while the mean central mac ular thickness was also significantly lower in group 2. However, there was no longer any difference between the 2 groups at 3, 4 and 6 months, neither in terms of visual acuity nor in terms of retinal thickness. More than three IVBs were needed in 3 of 10 patients in group 1 while 2 IVDs were required in 10 of 11 patients in group 2. 


\section{Table 2. Excluded studies (Continued)}

Hanhart $2017 \quad$ Non-randomised combination comparative study in CRVO and BRVO. Fifteen eyes were switched to ranibizumab, 12 to aflibercept, and 10 to dexamethasone. At 3, 6, 9, and 12 months, the outcome measures were visual acuity (VA) and central macular thickness (CMT).
1 year after the switch, CMT decreased from $430.11 \pm$ 91.21 to $291.86 \pm 43.87 \mu \mathrm{m}(\mathrm{P}<0.001)$. VA increased in $59.5 \%$ of the eyes. No difference between the groups was found in those outcomes at 1 year, but the number of injections varied: $3.30 \pm 0.95$ for dexamethasone, $6.50 \pm$ 2.11 for aflibercept, and $8.27 \pm 2.37$ for ranibizumab ( $P<$ $0.001)$.

Combination therapy of laser photocoagulation and single intravitreal bevacizumab injection resulted in a significantly better visual acuity compared to laser photocoagulation therapy ( 0.35 versus $0.13 \log M A R ; P=0.041$ ) and reduced macular thickness by $120.33 \mu \mathrm{m}$ versus $71.50 \mu \mathrm{m}(P=0.277)$, although this difference was not significant. group of 10 patients in the laser photocoagulation therapy. Complete ophthalmologic examinations were performed just before the therapy and at 1 month following the therapy.

\begin{abstract}
Leitritz 2013 In this prospective interventional consecutive case series, previously untreated eyes with perfused MO were enclosed over a period of 16 months for bevacizumab (BEV) and for 29 months for grid laser photocoagulation (GLP). The follow-up period was 1 year. Patients with persistent $\mathrm{MO}$ after 12 months of BEV were offered GLP and vice versa, and were followed up for another 12 months.
\end{abstract}

Both BEV (23 eyes) and GLP (21 eyes) caused a significant $(P<0.05)$ reduction in central retinal thickness $(C R T)$ at 12 months although this was delayed with GLP. However, BEV revealed a significantly better 'best-corrected visual acuity' (BCVA) compared with GLP (0.2 vs 0.5 log$M A R ; P<0.04)$. Switching therapy for non-responders revealed a reduced CRT at another 12 months, although this was not significant.

Liu 2014 42 confirmed cases (42 eyes) with macular oede-
ma secondary to BRVO were randomised into
3 groups, each group contained 14 eyes. The
ranibizumab group received intravitreal injec-
tion of ranibizumab $(0.05 \mathrm{~mL})$, the laser group
received grid laser photocoagulation, and the
combined group received a second therapy of
grid laser photocoagulation after 1 wk of the in-
travitreal injection of ranibizumab. Best-correct-
ed visual acuity (BCVA) and the central macu-
lar thickness (CMT) preoperative and at 1, 3, 6
months after therapy was recorded.

Klimes 2015

\begin{abstract}
A 25-health-state Markov model considering ranges of visual acuity in both eyes was developed. Patients had a confirmed diagnosis of macular oedema secondary to BRVO and had best-corrected visual acuity (BCVA) at baseline between 25 and 73 letters. The evaluation compared IVT-AFL $2 \mathrm{mg}$ with ranibizumab $0.5 \mathrm{mg}$ : the frequency of injections and monitoring were identical for both treatments, taken from randomised trials and a physician survey. A systematic review and indirect comparison were conducted to determine the probabilities of gaining at least 15 BCVA letters from baseline to 6 months; BCVA was then extrapolated over time to determine costs and outcomes. Utilities were taken from published literature and costs were
\end{abstract}

\begin{abstract}
The BCVA and the CMT had no differences among 3 groups pretherapy $(P>0.05)$. While BCVA was much better and CMT was reduced significantly post-therapy than pre-therapy in all 3 groups $(P<0.05)$. The BCVA and CMT in the ranibizumab group were significantly different in every time point $(1,3,6$ months) $(P<0.05)$. The BCVA declined and the CMT was thicker as time went on. In the laser group and the combined group, BCVA and CMT had little differences at different time points $(P>0.05)$; while the BCVA was better and the CMT was thinner in the combined group than ranibizumab group and laser group at every time point $(P<0.05)$. At 3 and 6 months, the BCVA was better and the CMT was thinner in laser group than ranibizumab group $(P<0.05)$.
\end{abstract}

The indirect comparison found that IVT-AFL was associated with a small numerical advantage in the likelihood of gaining 15 BCVA letters, compared with ranibizumab ( median odds ratio $=1.08,95 \% \mathrm{Cl} 0.43$ to 2.56 ). IVT-AFL was associated with a higher number of QALYs (0.045) per patient than ranibizumab. Both treatments are available to the National Health Service under confidential patient access schemes. Cost effectiveness was estimated for a range of possible discounts for each treatment. At price parity, IVT-AFL reduces cost by GBP 4 per patient and was a dominant therapy. Results were sensitive to the unit cost of the drugs used, to comparative efficacy and number of injections for both treatments. 
Table 2. Excluded studies (Continued)

estimated from a UK payer perspective. Published drug prices were discounted to reflect patient access schemes. Costs and benefits were discounted at $3.5 \%$.

MARVEL In this prospective, randomised, non-inferiority trial, 75 participants with macular oedema due to BRVO received intravitreal injections of ranibizumab (IVR) or bevacizumab (IVB) after 1:1 block randomisation. The primary outcome measure was the difference in mean changes in best-corrected visual acuity (BCVA) at 6 months. Secondary outcome measures included mean change in central retinal thickness (CRT), the proportion of patients improving by $>15$ letters and the proportion of patients developing neovascularisation.
Participants received either IVR $(n=37)$ or IVB $(n=$ 38). The mean $B C V A$ at baseline was $52.8 \pm 14.4$ letters $(20 / 80)$ and $56.1 \pm 10.0$ letters $(20 / 80)(P=0.24)$ in the ranibizumab and bevacizumab groups, respectively. At 6 months, the mean gains in BCVA were +18.1 letters $(95 \% \mathrm{Cl}+12.8$ to +22.6 ; $\mathrm{P}<0.0001)$ in the ranibizumab group and +15.6 letters $(95 \% \mathrm{Cl}+12.0$ to +20.5 ; $\mathrm{P}<$ 0.0001 ) in the bevacizumab group. The difference between the mean visual gains of the treated groups (bevacizumab-ranibizumab) was -2.5 letters $(95 \% \mathrm{Cl}-8.0$ to $+5.0 ; P=0.74)$. Mean reductions in CRT at 6 months were $177.1 \pm 122.3 \mathrm{~mm}$ in the ranibizumab group $(\mathrm{P}<$ 0.0001 ) and $201.7 \pm 166.2 \mathrm{~mm}$ in the bevacizumab group $(P<0.0001)$, with no significant difference between the 2 groups $(P=0.48)$. The mean numbers of ranibizum$\mathrm{ab}$ and bevacizumab injections were $3.2 \pm 1.5$ and $3.0 \pm$ 1.4 , respectively $(P=0.55)$. 2 serious adverse events occurred in the ranibizumab group and 1 in the bevacizumab group but both were unrelated to intravitreal injections.

BCVA showed significant improvement in 2 groups at 6 months. In addition, CMT showed significant decrease in 2 groups at 6 months. No significant differences in the change of BCVA and CMT at 6 months after injection ( $P$ $=0.973, P=0.639$ ) were observed between the 2 groups. A statistically significant difference was found regarding the number of additional IVB injections (IVB group $0.96 \pm$ 0.83 ; IVB/STA group $0.44 \pm 0.70, \mathrm{P}=0.034$ ). if optical coherence tomography (OCT) showed recurrent $\mathrm{ME}$ associated with decreased visual acuity. The main outcome measurement was the number of additional IVB injections, and changes of best-corrected visual acuity (BCVA) and central macular thickness (CMT) during a 6month follow-up period were compared.

\section{Moradian 201181 eyes with acute ( $<3$ months) BRVO were ran-} domly assigned to receive either 2 injections of $1.25 \mathrm{mg}$ bevacizumab 6 weeks apart or sham injections. Follow-up results were reported at 6 weeks and 12 weeks.
After week 6, visual improvements in the bevacizumab treated group were significantly better than the sham group. At 12 weeks there was no significant difference. There was a significant reduction in CMT both at 6 and at 12 weeks.
Ramezani 2014
In this randomised clinical trial, 86 eyes with recent onset ( $<12$ weeks) CRVO were assigned to 2 groups: bevacizumab (IVB) group (43 eyes) that received 3 monthly injections of $1.25 \mathrm{mg}$ of IVB, and triamcinolone (IVT) group (43 eyes) that received 2 injections of $2 \mathrm{mg}$ IVT 2 months apart. Outcomes were best-corrected visual acuity (BC$\mathrm{VA})$, central macular thickness (CMT), and intraocular pressure (IOP) changes.
Mean BCVA improved significantly at 6 months in both groups; from $0.87 \pm 0.49$ to $0.41 \pm 0.35 \log M A R$ in IVB group, and from $0.81 \pm 0.45$ to $0.62 \pm 0.48 \log M A R$ in IVT group $(P<0.001)$. However, between-group differences reach a significant level at months $4(P=0.003)$ and $6(P<$ 0.001 ) in favour of the IVB group. In terms of CMT reduction, the difference between the groups was statistically significant $(P=0.002)$ at month 6 . Significant differences were noted more in the ischaemic cases in favour of the IVB group. Mean IOP rise was significantly higher in the IVT group at all visits. 


\section{Table 2. Excluded studies (Continued)}

Regnier 2015

A Bayesian network meta-analysis of RCTs of treatments for macular oedema secondary to BRVO. Interventions: ranibizumab $0.5 \mathrm{mg}$ when necessary, aflibercept $2 \mathrm{mg}$ monthly, dexamethasone $0.7 \mathrm{mg}$ implant, laser photocoagulation, ranibizumab + laser, or sham intervention. Bevacizumab and triamcinolone were excluded.
8 RCTs were identified for inclusion with 1743 adult patients. The probability of being the most efficacious treatment at month 6 or 12 based on letters gained was $54 \%$ for ranibizumab monotherapy, 30\% for aflibercept, $16 \%$ for ranibizumab plus laser (adjunctive or prompt), and $0 \%$ for dexamethasone implant, laser or sham. The probability of being the most efficacious treatment for patients gaining $\geq 15$ letters was $39 \%$ for aflibercept, $35 \%$ for ranibizumab monotherapy, $24 \%$ for ranibizumab plus laser, $2 \%$ for dexamethasone implant, and less than $1 \%$ for laser or sham. There was no statistical difference between ranibizumab monotherapy and aflibercept for letters gained $(+1.4$ letters for ranibizumab vs aflibercept with $95 \%$ credible interval ( $\mathrm{Crl}$ ) of -5.2 to +8.5 letters) or the OR for gaining $\geq 15$ letters: 1.06 ( $95 \% \mathrm{Crl} 0.16$ to 8.94)). Dexamethasone implant was associated with significantly higher IOP/OH than antivascular endothelial growth factor agents (OR 13.1 (95\% Crl 1.7 to 116.9$)$ ).

The laser arm showed improvement in VA of 0.21 and $0.20 \log M A R$ at 6 and 12 months, respectively. The bevacizumab arm showed mean VA improvement at 6 and 12 months of 0.30 and 0.31 , respectively $(P<0.05)$. CRT decreased by $42 \%$ in the laser arm and $60.3 \%$ in the bevacizumab arm at 12 months $(P<0.05)$.
SHORE 2014
A quasi-RCT of 30 eyes in 30 patients in a single centre in Italy. 15 eyes received bevacizumab whilst 15 eyes received laser treatment. Follow-up was for 12 months.
Participants received monthly injections of 0.5 $\mathrm{mg}$ ranibizumab for 7 months and those meeting

stability criteria between months 7 and 14 were randomised (1:1) to 'as needed' injections versus continued monthly injections.
There was no significant difference in the slope of change in BCVA between months 7 and 15 in patients treated 'as needed' versus those treated with monthly injections $(P=0.509)$. Mean (standard deviation) change from baseline BCVA in Early Treatment Diabetic Retinopathy Study letter score at month 15 was 21.0 \pm 14.1 in the PRN group $(n=82)$ versus $18.7 \pm 14.1$ in the monthly group $(n=80)$ and $14.5 \pm 14.7$ in NR participants $(n=13)$. The percentage of participants who achieved BCVA $20 / 40$ at month 15 was $76.8 \%$ in the PRN group, $71.3 \%$ in the monthly group, and $46.2 \%$ in NR participants. The mean (standard deviation) change from baseline central subfield thickness was $247.8 \pm 207.5 \mathrm{~mm}$ in the PRN group, $289.9 \pm 177.2 \mathrm{~mm}$ in the monthly group, and $93.2 \pm 225.2 \mathrm{~mm}$ in NR participants. There were no significant differences in mean BCVA gains or central subfield thickness reductions at month 15 between the PRN and monthly injection groups (all >0.05).

38 patients were enrolled and randomised to IVB group $(n=19)$ and IVB + TRP group $(n=19)$. Both groups showed similar thinning in CRT at 1 week after IVB. The IVB + TRP group maintained thinner CRT at $2(P=0.0072)$ and $3(P=0.0086)$ months compared with IVB group. However, the difference in CRT became insignificant at 4,5 and 6 months. The number of reinjections ( \pm standard deviation) in IVB group $(1.58 \pm 0.69)$ was significantly greater $(P=0.0025)$ than that in IVB + TRP group $(0.83 \pm 0.62)$. BCVA significantly improved at 6 month in IVB + TRP group $(P=0.015)$, but not in IVB group. ed visual acuity (BCVA) and central retinal thickness (CRT) determined by optical coherence tomography were measured every month for 6 months. 
Table 2. Excluded studies (Continued)

Wroblewski 201020 eyes were randomised 3:1 to intravitreous injections of pegaptanib 0.3 or $1 \mathrm{mg}$ at baseline and at weeks 6 and 12 with subsequent injections at 6-week intervals at investigator discretion until week 48. Principal efficacy outcomes were change from baseline to week 54 .
Results were similar in both dosage groups. Mean BCVA improved 14 letters and mean CMT decreased by $205 \mathrm{mi}-$ crons.
Zhang $2014 \quad 30$ eyes of 30 patients with BRVO were randomised into 3 groups: group 1 (10 eyes) received grid laser treatment alone, group 2 received a single dose of intravitreal injection of ranibizumab $(0.05 \mathrm{~mL} / 0.5 \mathrm{mg})$ followed by grid laser treatment 7 days following injection. Group 3 (10 eyes) received 3 loading doses of intravitreal ranibizumab with grid laser treatment 7 days after the first injection. After 6 months follow-up, the best-corrected visual acuity and optical coherence tomography (OCT) and central macular thickness were observed.
After 6 months, the visual acuity of patients was improved significantly. There was an average increase of 11 letters, 17 letters and 18 letters in group 1, 2, and 3 respectively, with the average decrease in OCT being 208.7 mum, 312.9 mum and 326.8 mum, respectively, in these groups. Gain in visual acuity more than 3 lines was 1 case $(10 \%)$ in group 1 . There were 3 cases $(30 \%)$ in group 2 and 4 cases $(40 \%)$ in group 3.

BCVA: best-corrected visual acuity; BRVO: branch retinal vein occlusion; CMT: central macular thickness; CRVO: central retinal vein occlusion; IVB: intravitreal bevacizumab; MO: macular oedema; OCT: optical coherence tomography

\section{APPENDICES}

\section{Appendix 1. CENTRAL search strategy}

\#1 MeSH descriptor: [Macular Edema] explode all trees

\#2 MeSH descriptor: [Edema] explode all trees

\#3 MeSH descriptor: [Macula Lutea] explode all trees

\#4 macula* near/3 oedema

\#5 macula* near/3 edema

\#6 CME or CMO

$\# 7$ (\#1 or \#2 or \#3 or \#4 or \#5 or \#6)

\#8 MeSH descriptor: [Retinal Vein Occlusion] explode all trees

\#9 MeSH descriptor: [Retinal Vein] explode all trees

\#10 retina* near/3 (vein ${ }^{\star}$ or occlu* or obstruct* or clos* or stricture* or steno* or block* or embolism*)

\#11 BRVO or RVO

$\# 12$ branch retinal vein occlusion

$\# 13$ (\#8 or \#9 or \#10 or \#11 or \#12)

\#14 MeSH descriptor: [Angiogenesis Inhibitors] explode all trees

\#15 MeSH descriptor: [Angiogenesis Inducing Agents] explode all trees

\#16 MeSH descriptor: [Endothelial Growth Factors] explode all trees

\#17 MeSH descriptor: [Vascular Endothelial Growth Factors] explode all trees

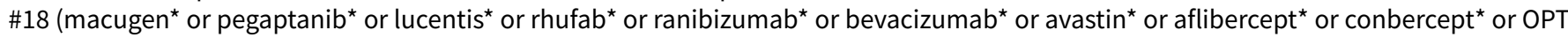

302 or Opthea* or RTH258 or Brolucizumab* or abicipar pegol)

\#19 anti near/2 VEGF*

$\# 20$ anti near/1 angiogen*

\#21 endothelial near/2 growth near/2 factor ${ }^{*}$

\#22 VEGF TRAP*

$\# 23$ (\#14 or \#15 or \#16 or \#17 or \#18 or \#19 or \#20 or \#21 or \#22)

$\# 24 \# 7$ and \#13 and \#23

\section{Appendix 2. MEDLINE Ovid search strategy}

1. randomized controlled trial.pt.

2. (randomized or randomised).ab,ti.

3. placebo.ab,ti. 
4. dt.fs.

5. randomly.ab,ti.

6. trial.ab,ti.

7. groups.ab,ti.

8. or/1-7

9. exp animals/

10. exp humans/

11. 9 not (9 and 10)

12. 8 not 11

13. macular edema/

14. exp edema/

15. macula lutea/

16. (macula\$ adj3 oedema).tw.

17. (macula\$ adj3 edema).tw.

18. (CME or CMO).tw.

19. or/13-18

20. retinal vein occlusion/

21. retinal vein/

22. ((vein\$ or occlu\$ or obstruct\$ or clos\$ or stricture\$ or steno $\$$ or block\$ or embolism\$) adj3 retina\$).tw.

23. branch retinal vein occlusion.tw.

24. (BRVO or RVO).tw.

25. or/20-24

26. exp angiogenesis inhibitors/

27. angiogenesis inducing agents/

28. endothelial growth factors/

29. exp vascular endothelial growth factors/

30. (macugen $\$$ or pegaptanib\$ or lucentis $\$$ or rhufab\$ or ranibizumab\$ or bevacizumab\$ or avastin or aflibercept\$ or conbercept\$ or OPT

302 or Opthea\$ or RTH258 or Brolucizumab\$ or abicipar pegol).tw.

31. (anti adj2 VEGF\$).tw.

32. (anti adj1 angiogen\$).tw.

33. (endothelial adj2 growth adj2 factor\$).tw.

34. VEGF TRAP\$.tw.

35. or/26-34

36. 19 and 25 and 35

37. 12 and 36

The search filter for trials at the beginning of the MEDLINE strategy is from the published paper by Glanville 2006.

\section{Appendix 3. Embase Ovid search strategy}

1. exp randomized controlled trial/

2. exp randomization/

3. exp double blind procedure/

4. exp single blind procedure/

5. random\$.tw.

6. or/1-5

7. (animal or animal experiment).sh.

8. human.sh.

9.7 and 8

10.7 not 9

11.6 not 10

12. exp clinical trial/

13. (clin\$ adj3 trial\$).tw.

14. ((singl\$ or doubl\$ or trebl\$ or tripl\$) adj3 (blind\$ or mask\$)).tw.

15. exp placebo/

16. placebo\$.tw.

17. random\$.tw.

18. exp experimental design/

19. exp crossover procedure/

20. exp control group/

21. exp latin square design/

22. or/12-21 
23. 22 not 10

24. 23 not 11

25. exp comparative study/

26. exp evaluation/

27. exp prospective study/

28. (control\$ or propspectiv\$ or volunteer\$).tw.

29. or $/ 25-28$

30.29 not 10

31.30 not (11 or 23$)$

32. 11 or 24 or 31

33. exp retina macula edema/

34. eye edema/

35. retina macula lutea/

36. (macula $\$$ adj3 oedema).tw.

37. (macula\$ adj3 edema).tw.

38. (CME or CMO).tw.

39. or/33-38

40. exp retina vein occlusion/

41. retina vein/

42. ((vein\$ or occlu\$ or obstruct\$ or clos\$ or stricture\$ or steno\$ or block\$ or embolism\$) adj3 retina\$).tw.

43. branch retinal vein occlusion.tw.

44. (BRVO or RVO).tw.

45. or/40-44

46. angiogenesis/

47. exp angiogenesis inhibitors/

48. angiogenic factor/

49. endothelial cell growth factor/

50. exp vasculotropin/

51. (macugen\$ or pegaptanib\$ or lucentis\$ or rhufab\$ or ranibizumab\$ or bevacizumab\$ or avastin or aflibercept\$ or conbercept\$ or OPT

302 or Opthea\$ or RTH258 or Brolucizumab\$ or abicipar pegol).tw.

52. (anti adj2 VEGF\$).tw.

53. (anti adj1 angiogen\$).tw.

54. (endothelial adj2 growth adj2 factor\$).tw.

55. VEGF TRAP\$.tw.

56. or/46-55

57.39 and 45 and 56

58.32 and 57

\section{Appendix 4. LILACS search strategy}

(tw:(macular oedema OR macular edema)) AND (tw:(vein* OR occlu^ OR obstruct* OR clos* OR stricture* OR steno* OR block ${ }^{\star}$ OR embolism* OR brvo)) AND (tw: (angiogenesis OR endothelial growth factor OR macugen ${ }^{\star}$ OR pegaptanib* OR lucentis* OR rhufab* OR ranibizumab* OR bevacizumab* OR avastin OR aflibercept* OR conbercept* or OPT 302 or Opthea* or RTH258 or Brolucizumab* or abicipar pegol))

\section{Appendix 5. ISRCTN search strategy}

"(macular oedema OR macular edema) AND (branch retinal vein occlusion OR BRVO OR vein OR occlusion OR obstruction OR closure OR stricture OR stenosis OR blockage OR embolism)"

\section{Appendix 6. ClinicalTrials.gov search strategy}

Interventional Studies | (macular oedema OR macular edema) AND (branch retinal vein occlusion OR BRVO OR vein OR occlusion OR obstruction OR closure OR stricture OR stenosis OR blockage OR embolism)

\section{Appendix 7. WHO ICTRP search strategy}

branch retinal vein occlusion AND macular oedema

\section{WHAT'S NEW}




\begin{tabular}{lll}
\hline Date & Event & Description \\
\hline 27 March 2020 & New search has been performed & $\begin{array}{l}\text { Issue 7 2020: Electronic searches were updated. New author, } \\
\text { Zaid Shalchi joined the team. }\end{array}$ \\
\hline 27 March 2020 & $\begin{array}{l}\text { New citation required and conclusions } \\
\text { have changed }\end{array}$ & $\begin{array}{l}\text { Issue 7 2020: Eight new studies were included in this update } \\
\text { (Bandello 2018; BLOSSOM; BRIGHTER; COMRADE-B; Higashiyama } \\
\text { 2013; RABAMES; Ramezani 2012; VIBRANT) and two previously in- } \\
\text { cluded studies were excluded (BRAVO 2010; Russo 2009). }\end{array}$ \\
\hline
\end{tabular}

\section{HIST O R Y}

Protocol first published: Issue 12, 2011

Review first published: Issue 1, 2013

\section{CONTRIBUTIONS OFAUTHORS}

\section{0 update}

Conceiving the review: Cochrane Eyes and Vision

Designing the review: DM, ZS

Co-ordinating the review: DM, ZS

Data collection for the review:

- Designing electronic search strategies: Cochrane Eyes and Vision Group editorial base

- Undertaking manual searches: DM, ZS

- Screening search results: DM, ZS, OM

- Organising retrieval of papers: DM, ZS

- Screening retrieved papers against inclusion criteria: DM, ZS

- Appraising quality of papers: DM, ZS

- Extracting data from papers: DM, ZS

- Writing to authors of papers for additional information: DM, ZS

- Providing additional data about papers: DM, ZS

- Obtaining and screening data on unpublished studies: DM, ZS

Data management for the review

- Entering data into RevMan 5: DM, ZS

- Checking that data entered into RevMan 5 is correct: DM, ZS

Analysis of data: CB, DM, ZS

- Interpretation of data

- Providing a methodological perspective: $\mathrm{CB}, \mathrm{DM}$

- Providing a clinical perspective: DM, ZS, OM

- Providing a policy perspective: $\mathrm{CB}$

Writing the review: DM, ZS

Providing general advice on the review: CB, DM, ZS, OM

\section{DECLARATIONS OF INTEREST}

No authors have any financial or proprietary interest in any product mentioned. 


\section{SOURCES OF SUPPORT}

\section{Internal sources}

- National Institute for Health Research (NIHR), UK

Catey Bunce acknowledges financial support from the Department of Health through the award made by the National Institute for Health Research to Moorfields Eye Hospital NHS Foundation Trust and UCL Institute of Ophthalmology for a Specialist Biomedical Research Centre for Ophthalmology. The views expressed in this publication are those of the authors and not necessarily those of the Department of Health.

\section{External sources}

- No sources of support supplied

\section{DIFFERENCES BETWEEN PROTOCOLANDREVIEW}

There were no differences between the protocol and this updated 2020 version of the review. In the first version of this review, a paucity of RCTs meant two studies were included that this subsequent update has excluded. Russo 2009, a quasi-RCT has been excluded as new RCT data from other studies has became available. BRAVO 2010 has now been excluded due to the ability for both the sham and anti-VEGF arms to receive rescue laser, and this combination therapy is specifically excluded by the protocol.

\section{INDEX TERMS}

\section{Medical Subject Headings (MeSH)}

Angiogenesis Inhibitors [ ${ }^{*}$ administration \& dosage] [adverse effects]; Antibodies, Monoclonal, Humanized [ ${ }^{*}$ administration \& dosage] [adverse effects]; Bevacizumab; Intravitreal Injections; Laser Coagulation; Macular Edema [ ${ }^{*}$ drug therapy] [etiology] [surgery]; Randomized Controlled Trials as Topic; Ranibizumab; Retinal Vein Occlusion [ ${ }^{\star}$ complications]; Salvage Therapy [methods]; Vascular Endothelial Growth Factor A [*antagonists \& inhibitors]

\section{MeSH check words}

Humans 